\title{
ELUCIDATION OF FLOW AND TRANSPORT PROCESSES IN A VARIABLY- SATURATED SYSTEM OF INTERLAYERED SEDIMENT AND FRACTURED ROCK USING TRACER TESTS
}

\author{
by
}

Catherine L. Duke

\begin{abstract}
Submitted in Partial Fulfillment of the Requirements for the Degree of

Master of Science in Hydrology

New Mexico Institute of Mining and Technology Department of Earth and Environmental Science
\end{abstract}

Socorro, New Mexico

May 2008 


\begin{abstract}
The objective of this work was to investigate flow and transport in a layered, variably-saturated system consisting of both fractured rock and sedimentary material during focused infiltration from the surface. Two tracer tests were carried out using the Vadose Zone Research Park (VZRP) at Idaho National Laboratory (INL). The first test was conducted under quasi-steady-state conditions and the second was initiated in a much drier system and thus provided information regarding flow and transport under transient conditions. A one-dimensional analytical model was used to fit breakthrough curves resulting from the two tracer tests. The results of this modeling provide insight into the nature of flow in the fractured basalt, surficial alluvium, and sedimentary interbeds that comprise the vadose zone of the eastern Snake River Plain. Flow through the fractured basalt is focused and preferential in nature and multiple flow paths arise due to numerous fractures functioning as transmissive pathways in addition to flow splitting along geologic contacts. Flow velocities were significantly higher during the test with the wetter flow domain, presumably due to increases in hydraulic conductivity associated with higher water contents of the geologic materials. Perching was observed above the alluvium/basalt contact and above the lower boundary of a locally continuous sedimentary interbed. The perching behavior between the two contacts was fundamentally different; the perched layer above the alluvium/basalt contact was neither laterally extensive nor temporally persistent in the absence of infiltration from the
\end{abstract}


surface. In contrast, the perched layer along the interbed was significantly thicker and gave rise to lateral flow over distances on the order of 100s of meters. Vertical transport is shown to occur predominantly through the main bulk of the sedimentary material of the interbed rather than through preferential pathways; lateral flow appears to occur primarily in the fractured basalt directly above the interbed. 


\section{ACKNOWLEDGEMENTS}

This work was supported through a grant from the Environmental Management Science Program of the Office of Science, U.S. Department of Energy to Dr. Robert Roback, Los Alamos National Laboratory.

I would like to thank the members of my committee, Dr. Robert Bowman, Dr. Jan Hendrickx, Dr. Fred Phillips, Dr. Robert Roback, and Dr. John Wilson. In addition, I would like to thank Leah Street and her crew at Idaho National Laboratory for great field support, Beth Nichols and Ryan Channel for help both in the field and in the laboratory, and Cindy Dean for her friendship and support. Special thanks to Dr. Paul Reimus for technical support and informative discussions. 


\section{TABLE OF CONTENTS}

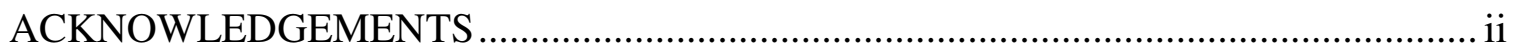

TABLE OF CONTENTS ........................................................................................

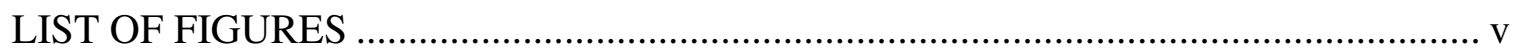

LIST OF APPENDIX FIGURES.......................................................................... vi

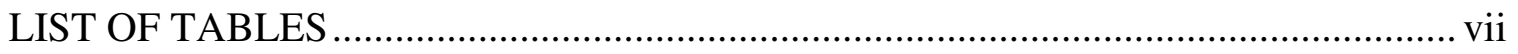

LIST OF APPENDIX TABLES ……………………........................................ vii

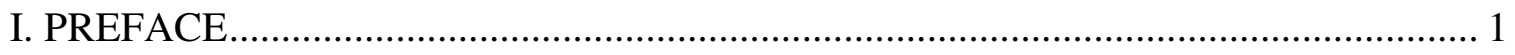

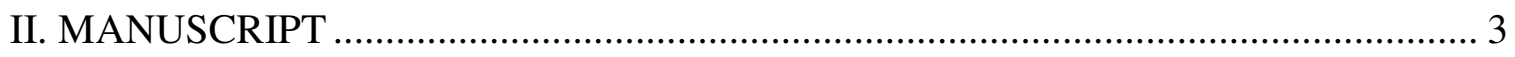

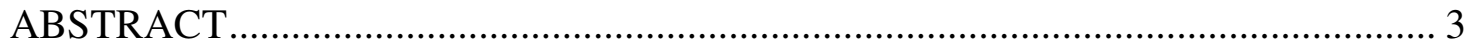

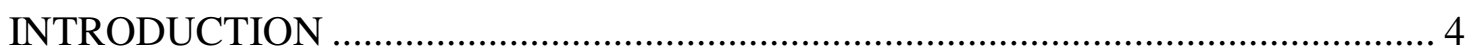

HYDROGEOLOGY OF THE EASTERN SNAKE RIVER PLAIN ………………..... 8

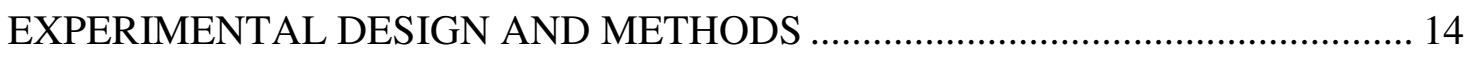

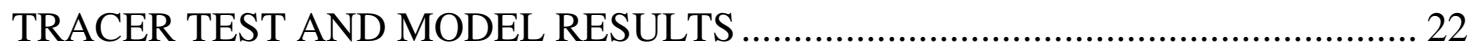

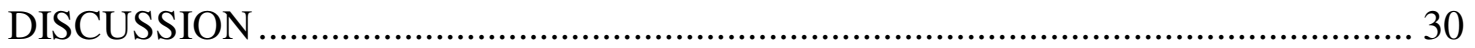

CONCLUSION

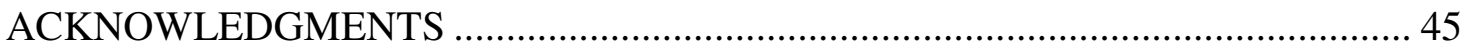

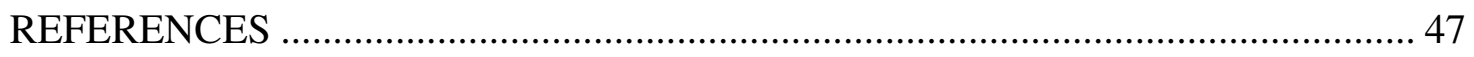

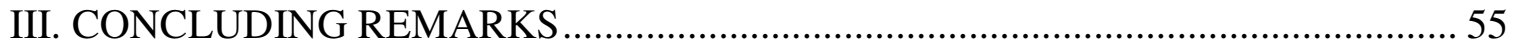

APPENDIX A: HIGH-PERFORMANCE LIQUID CHROMATOGRAPHY DATA..... 58 
APPENDIX B: CALCULATION OF VERTICAL SATURATED HYDRAULIC

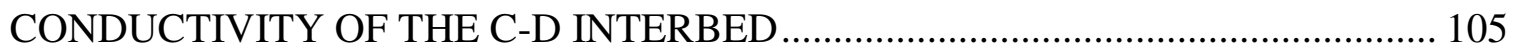

APPENDIX C: DISCUSSION OF POWER-LAW TAILING BEHAVIOR .................. 109

APPENDIX D: DISCUSSION OF DISPERSION COEFFICIENTS YIELDED BY

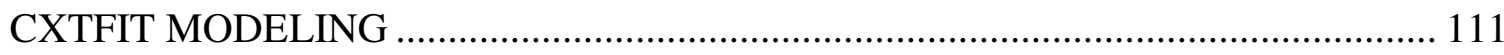

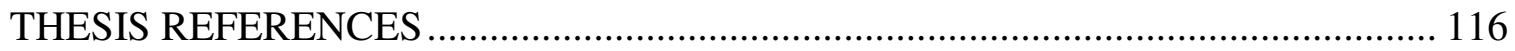




\section{LIST OF FIGURES}

Figure 1: Location of Vadose Zone Research Park (VZRP) and nearby facilities, the Radioactive Waste Management Complex (RWMC), Idaho Nuclear Technology and Engineering Center (INTEC), Test Reactor Area (TRA) and Central Facilities Area (CFA). Arrows in the inset indicate the direction of regional groundwater

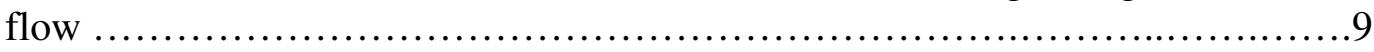

Figure 2: Map of infiltration ponds and associated near-field monitoring network at the Vadose Zone Research Park (VZRP)......................................16

Figure 3: Schematic cross-section showing lithology and monitoring network along the line of section shown in Fig. 2. Wells 202, 203(A), and 204 are projected into the line of section. Red symbols represent monitoring wells; blue symbols represent suction lysimeters.................................................

Figure 4: Test 1 and test 2 breakthrough curves from wells and lysimeters $(\mathrm{QL}=$

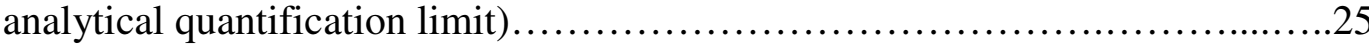

Figure 5: Representative fits of test 1 and test 2 data from which flow velocity estimates

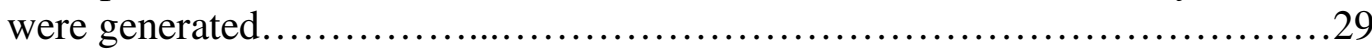

Figure 6: Prediction of well test 2 203(A) data using parameters from an inverse fit of test 2 well 199(A) BTC...........................................................

Figure 7: Test 2 breakthrough curves for well 202A(B) and lysimeter 204129(I)...........35

Figure 8: Results of CXTFIT simulations compared with test 2 well 212 breakthrough data (see text for conceptual model in each simulation).........................38 


\section{LIST OF APPENDIX FIGURES}

Figure C-1: BTCs from wells completed at the alluvium/basalt contact demonstrating

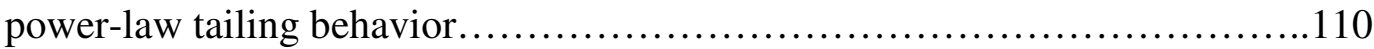

Figure D-1: Plot of longitudinal dispersivity (m) vs. transport distance (m)............114 


\section{LIST OF TABLES}

Table 1: Descriptions of wells and lysimeters that received water during tests ............ 21

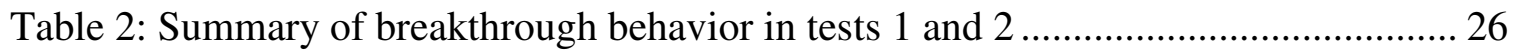

Table 3: Summary of flow velocities for both tracer tests........................................ 27 


\section{LIST OF APPENDIX TABLES}

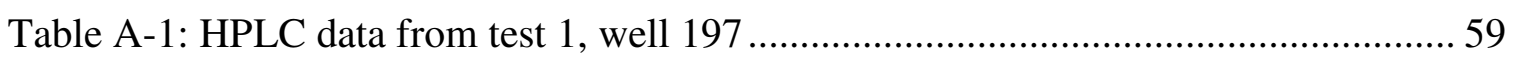

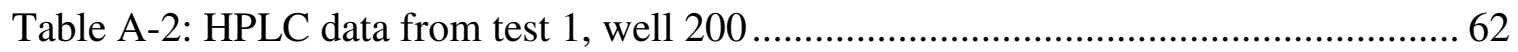

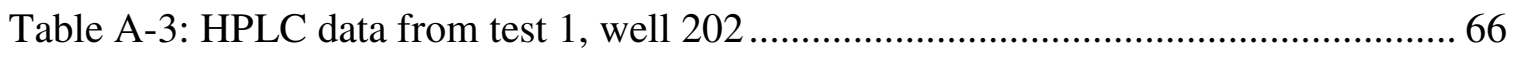

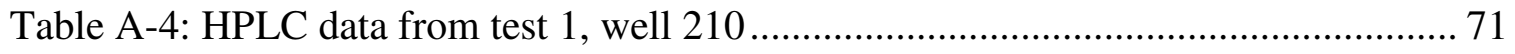

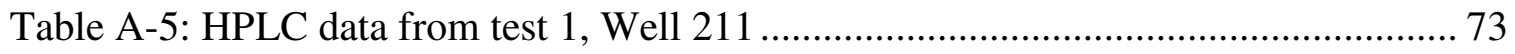

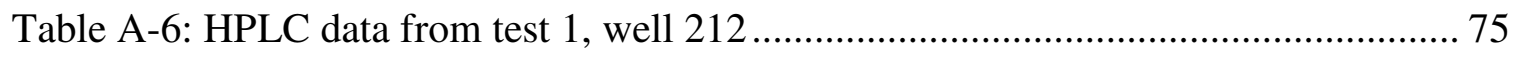

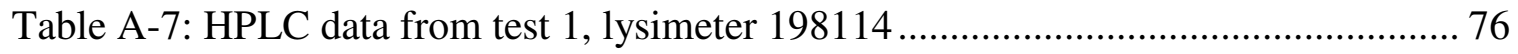

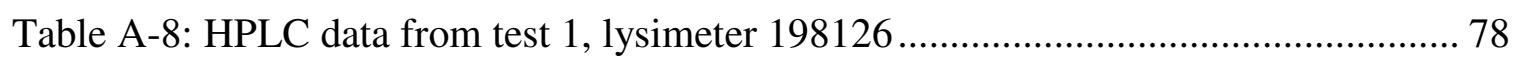

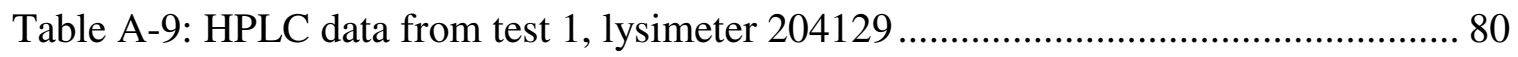

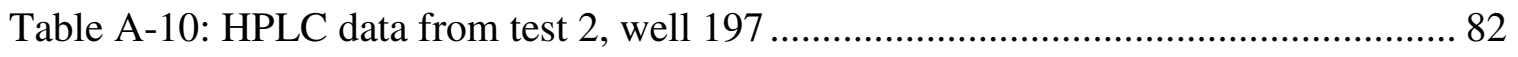

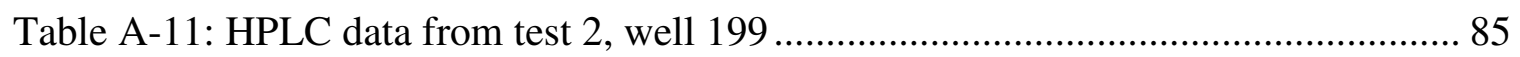

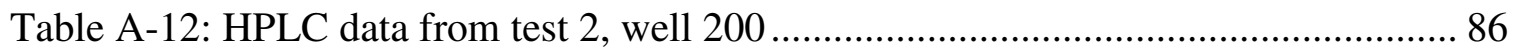

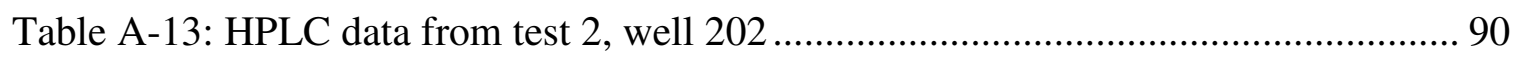

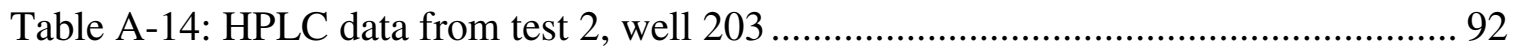

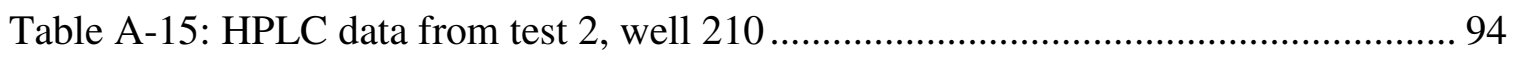

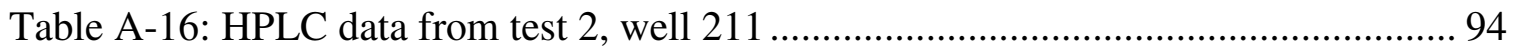

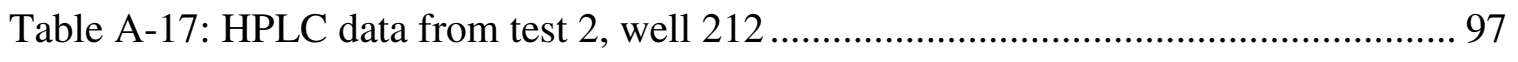

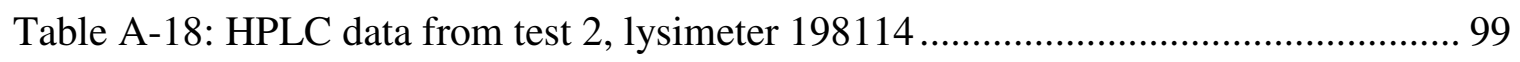

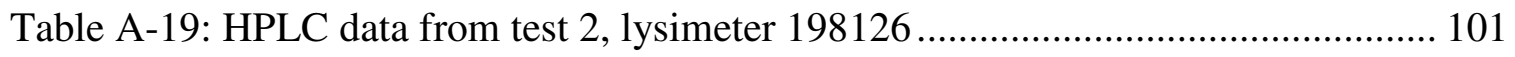


Table D-1: Summary of CXTFIT transport parameters and calculated dispersivities $(\alpha)$

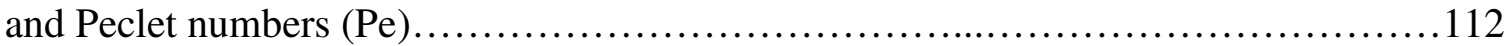




\section{PREFACE}

This document is the result of a thesis project completed in partial fulfillment of the requirements for a Master of Science degree in Hydrology. It includes a manuscript that was published in the Vadose Zone Journal (2007; 6:855-867), as well as supporting appendices containing tabulated analytical data, calculations, and detailed discussions of power-law tailing behavior and dispersivity values yielded by the modeling.

There is currently a great deal of interest in understanding flow and transport processes in variably-saturated and fractured geologic media both for the design and construction of waste repositories and for remediation of contaminated sites. The goal of this study was to identify and quantify the important processes occurring during infiltration and redistribution of water through the variably-saturated fractured basalts and associated sedimentary materials that comprise the vadose zone of the eastern Snake River Plain in Idaho. Two tracer tests were carried out using the Vadose Zone Research Park (VZRP) at Idaho National Laboratory (INL). The objectives of these tests were to corroborate and improve upon existing conceptual models of flow and transport in variably-saturated, layered systems consisting of both unconsolidated porous media and fractured rock, and to provide semi-quantitative estimates of site-specific transport parameters for INL. The two tracer tests were designed to interrogate the subsurface on spatial and temporal scales relevant to problems concerning mobilization of contaminants due to short (days to weeks) infiltration events as well as longer duration floods. 
This thesis in organized into three sections. Section I, the preface, describes the objectives of the work and the layout of the thesis. Section II contains a manuscript entitled "Elucidation of flow and transport processes in a variably-saturated system of inter-layered sediment and fractured rock using tracer test results" that was published in the Vadose Zone Journal. Small editorial corrections have been incorporated into this version of the manuscript. Explanation of calculations, and discussion of issues raised after the manuscript was published are located in the appendices. Section III presents concluding remarks aimed at defining this work in the context of the larger project, discussing the main conclusions of the paper, and suggesting future work.

Four appendices are presented. Appendix A contains the analytical data that were used to construct breakthrough curves discussed in the manuscript. Appendix B contains calculations associated with determining vertical saturated hydraulic conductivity values for the C-D interbed. Appendix C contains a discussion of the tailing behavior observed in the breakthrough curves generated in this study. Appendix D contains a discussion of the dispersion parameters computed using the CXTFIT code. A complete list of references, including those cited in Appendices C and D are listed at the end of the thesis in a section entitled "Thesis References". 


\title{
II. MANUSCRIPT
}

\section{Elucidation of flow and transport processes in a variably-saturated system of inter- layered sediment and fractured rock using tracer test results*}

*Duke, C.L., R.C. Roback, P.W. Reimus, R.S. Bowman, T.L. McLing, K.E. Baker, and L.C. Hull. 2007. Elucidation of flow and transport processes in a variably-saturated system of inter-layered sediment and fractured rock. Vadose Zone Journal, 6:855-867

\begin{abstract}
The objective of this work was to investigate flow and transport in a layered, variably-saturated system consisting of both fractured rock and sedimentary material during focused infiltration from the surface. Two tracer tests were carried out using the Vadose Zone Research Park (VZRP) at Idaho National Laboratory (INL). The first test occurred under quasi-steady-state conditions and the second was initiated in a much drier system and thus provided information regarding flow and transport under transient conditions. A one-dimensional analytical model was used to fit breakthrough curves resulting from the two tracer tests. The results of this modeling provide insight into the nature of flow in the fractured basalt, surficial alluvium, and sedimentary interbeds that comprise the vadose zone of the eastern Snake River Plain. Flow through the fractured basalt is focused and preferential in nature and multiple flow paths arise due to numerous
\end{abstract}


fractures functioning as transmissive pathways in addition to flow splitting along geologic contacts. Flow velocities were significantly higher during the test with the wetter flow domain, presumably due to increases in hydraulic conductivity associated with higher water contents of the geologic materials. Perching was observed above the alluvium/basalt contact and above the lower boundary of a locally continuous sedimentary interbed. The perching behavior between the two contacts was fundamentally different; the perched layer above the alluvium/basalt contact was neither laterally extensive nor temporally persistent in the absence of infiltration from the surface. In contrast, the perched layer along the interbed was significantly thicker and gave rise to lateral flow over distances on the order of 100s of meters. Vertical transport is shown to occur predominantly through the main bulk of the sedimentary material of the interbed rather than through preferential pathways; lateral flow appears to occur primarily in the fractured basalt directly above the interbed.

\section{INTRODUCTION}

Understanding flow and transport in variably-saturated, layered and fractured geologic systems is of critical importance in managing waste disposal and determining remediation strategies. For many contaminated sites the vadose zone is the only barrier between the source of contamination and the regional aquifer. Repositories for radioactive and hazardous wastes have been proposed in unsaturated, fractured rock that is expected to prevent contaminant release to the accessible environment. For many years it was thought that highly negative pressures within the unsaturated matrix of fractured rocks would prevent flow from occurring in the fractures until the surrounding matrix 
was saturated or close to saturated (Montazer and Wilson, 1984; Wang and Narasimhan, 1985, 1993; Peters and Klavetter, 1988). Thus, flow was expected to proceed at relatively low rates that could be predicted using Richard's equation-type formulations. However, growing evidence from both field experiments and numerical modeling efforts has shown that substantial flow does occur in fractures surrounded by unsaturated matrix (Fabryka-Martin et al., 1993, 1994; Faybishenko et al., 2000; Finsterle et al., 2002; Flint et al., 2001b; Gauthier et al., 1992; Illman and Hughson, 2005; Liu et al., 1998; Yang et al., 1996). This flow mechanism appears to be especially important during unsaturated flow associated with intense, episodic infiltration events (McLaren et al., 2000; Pruess, 1999). Fracture flow in unsaturated media gives rise to much faster contaminant travel times and lower effective sorption than would be predicted based on a matrix-flow conceptual model.

In deep vadose zones contacts between units of differing hydrogeologic characteristics (fractured vs. unfractured, consolidated vs. unconsolidated) have important implications for flow distribution (e.g. Adam et al., 2004; Flint et al., 2001a; Nimmo et al., 2004b; Robinson et al., 2005). Issues associated with such contacts include the formation of perched aquifers, interruption of vertical flow, and lateral diversion of infiltrating water. Perched aquifers may store significant amounts of water within the vadose zone and, as such, may act as reservoirs within which contaminants are either concentrated or diluted (Nimmo et al., 2004b). Lateral redistribution of water may serve to limit infiltration through a waste site or repository horizon, but can also act to divert polluted water to preferential pathways such as fault zones that provide fast paths to the regional aquifer (Flint et al., 2001a). Whether lateral flow occurs above or within 
an impeding layer has important implications for the rate at which flow may be expected to occur. In addition, the potential for sorption and other physico-chemical interaction between dissolved solutes and the rock will vary depending on the unit through which the solutes are being transported.

Radionuclide contamination in the vadose zone, and the potential for contaminant migration to the aquifer, is one of the most serious environmental concerns at Idaho National Laboratory (INL). At the Radioactive Waste Management Complex (RWMC), low-level radioactive wastes were buried in near-surface pits and trenches. At the Idaho Nuclear Technology and Engineering Center (INTEC, formerly the Idaho Chemical Processing Plant (ICPP)), spills and leaks from transfer lines have resulted in contamination of near-surface sediments as well as of perched water bodies deeper in the vadose zone. In order to predict the behavior of such contamination it is critical to understand the nature of flow in the vadose zone, in particular fracture/matrix interactions as well as the role of geologic contacts and the associated perched zones of saturation.

Over the past couple of decades, long-term monitoring, field-scale experiments, and associated modeling efforts have been carried out at INL. In particular, three tracer tests were carried out in the 1990s: the Large Scale Infiltration Test (LSIT), the Box Canyon tests, and the Spreading Area test (these tests are described in detail below). The goal of these studies was to reduce uncertainty in the conceptual understanding of flow and transport in this very complex hydrogeological setting as well as to provide site-specific transport parameters that can be used in risk assessment (Doughty, 2000; Dunnivant et al., 1998; Dunnivant et al., 1995; Faybishenko et al., 2000; Magnuson, 1995; Magnuson, 2004; Mattson, et al., 2004; Nimmo et al., 2002; Wood and Norrell, 1996). A relatively 
robust conceptual model has resulted from this work but several issues require further clarification. The effects of transient infiltration events and antecedent wetness on flow velocities (and therefore residence times in each geologic unit) have not been defined. In addition, understanding of perching mechanisms and the persistence and lateral extent of the resulting saturated layers is lacking. Although lateral flow is known to be associated with sedimentary interbeds it is not clear whether this flow occurs in the sedimentary material of the interbeds themselves or in the high-permeability basalt rubble zones with which the interbeds are often associated (Nimmo et al., 2004b). It is also unclear to what degree water bypasses the highly sorptive sedimentary materials of the interbeds due to flow mechanisms such as instability-linked flow fingering and funneling within the sediments or by accessing preferential flow paths through discontinuities in the interbed.

In order to address these issues and provide further clarification of the behavior of this system during high-flux infiltration from the surface we carried out two tracer tests utilizing the Vadose Zone Research Park (VZRP) at INL. Tracers were applied in two infiltration ponds and were sampled at three depths: at the base of the surficial alluvium where it contacts fractured basalt, within a laterally continuous and relatively thick sedimentary interbed (the C-D interbed), and at the interface between the fractured basalt and the top of the C-D interbed. The first tracer test was carried out under relatively wet, quasi-steady-state hydrologic conditions, whereas the second test investigated transport during infiltration into an initially dry system.

Both tracer tests yielded valuable information for INL as well as other sites with similar hydrogeologic systems in that: 1) they were carried out at a scale of 100 s of meters, which is directly relevant to questions regarding transport at the site- and facility- 
scale, 2) they investigated flow in the fractured basalt, in the surficial alluvium and in the interbed sediments, as well as at the contacts between these units, and 3) they simulated episodic infiltration events on two temporal scales that are of concern at INL and in other semiarid environments subject to both short-term, seasonal flooding (days-weeks) and longer duration floods of several months. Analysis of tracer test results facilitated by the use of a simple one-dimensional transport model provided insight into the nature of flow in each of the geologic units of concern and allowed comparison of transport behavior between units under differing infiltration conditions.

\section{HYDROGEOLOGY OF THE EASTERN SNAKE RIVER PLAIN}

INL occupies approximately $2300 \mathrm{~km}^{2}$ of the eastern Snake River Plain (ESRP) in southeast Idaho (Fig. 1). Underlying the plain is the Snake River Plain aquifer that provides agricultural and domestic water to much of southeastern Idaho. The vadose zone is approximately $60 \mathrm{~m}$ deep at the northern border of INL and thickens to around $200 \mathrm{~m}$ at the southern border. The eastern Snake River Plain hosts a thick sequence of Tertiary and Quaternary pahoehoe basalt flows that erupted from small shield volcanoes (Schaefer and Kattenhorn, 2004; Smith, 2004). Individual lava flows are low volume $\left(0.005-7 \mathrm{~km}^{3}\right)$ and have a fairly consistent and well-defined internal structure. Schaefer and Kattenhorn (2004) describe a typical basalt flow as having an upper and lower colonnade separated by a densely fractured entablature. Fractures in the upper colonnade are more closely spaced than those in the lower colonnade and are both column-bounding and column-normal. In contrast, the lower colonnade is distinguished by more sparsely 


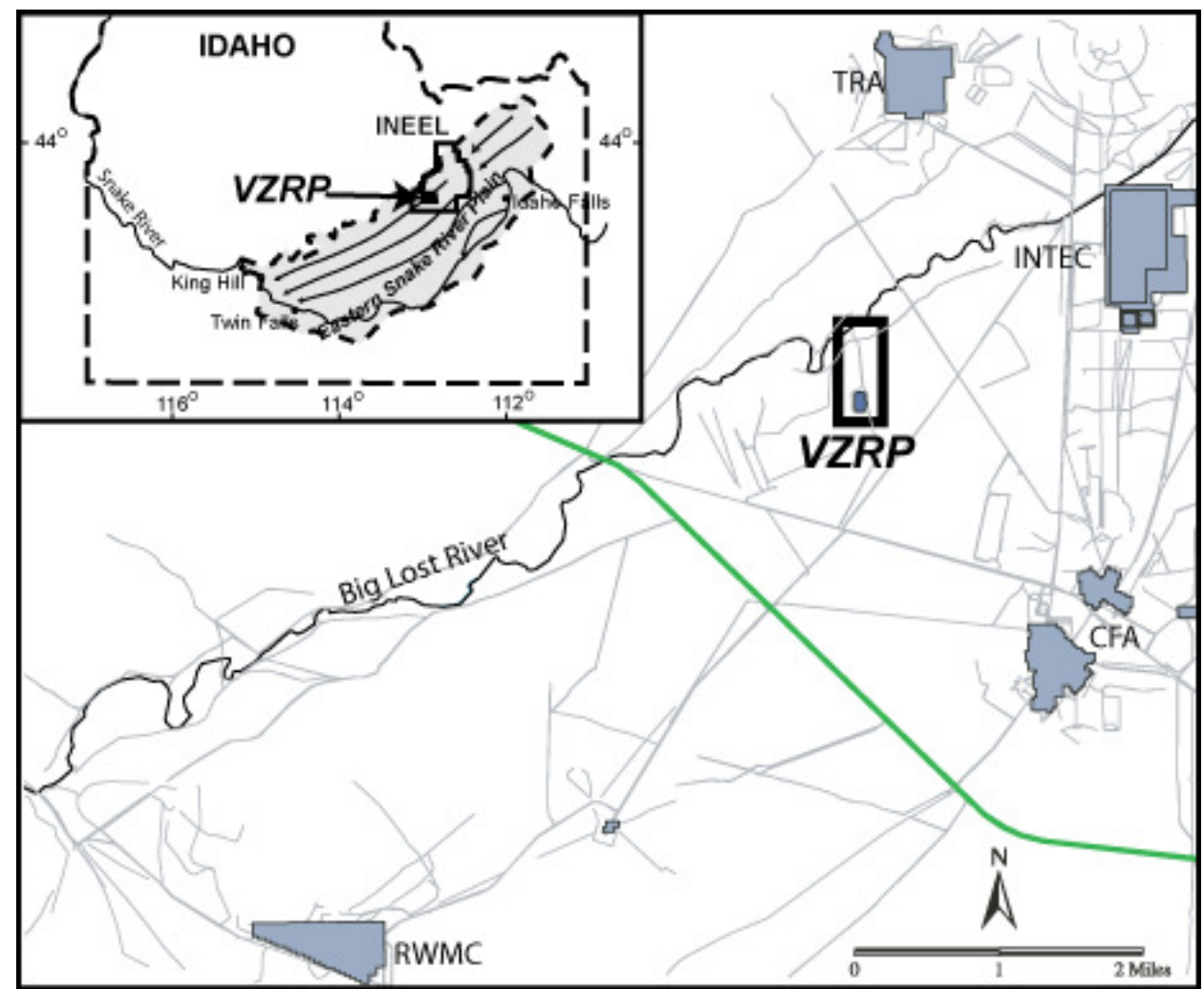

Figure 1: Location of Vadose Zone Research Park (VZRP) and nearby facilities, the Radioactive Waste Management Complex (RWMC), Idaho Nuclear Technology and Engineering Center (INTEC), Test Reactor Area (TRA) and Central Facilities Area (CFA). Arrows in the inset indicate direction of regional groundwater flow. Green and blue lines delineate area roads.

distributed fractures that are primarily column-bounding. The entablature, although intensely fractured, contains few column-bounding fractures with the majority of the fracturing sub-horizontal. This serves to prevent column-bounding fractures from the upper and lower colonnades connecting across the flow. Shaeffer and Kattenhorn (2004) state that entablatures are not present in all the flows that they studied, and this observation is supported by Faybishenko et al. (2000) who observed densely fractured sub-horizontal central zones in $\sim 40 \%$ of the flows examined at the Box Canyon site. Schaeffer and Kattenhorn suggest that column-bounding fractures are likely the features of greatest significance in controlling hydraulic conductivity within a single basalt flow 
as they are the longest and most connected fractures and have the greatest apertures. This idea is supported by the fact that column-bounding fractures are often lined with secondary minerals whereas entablature fractures generally are not. Faybishenko et al. (2000) also identified vertical to sub-vertical column-bounding fractures as the predominant flow pathway through individual basalt flows exposed at Box Canyon.

During periods of volcanic quiescence, sedimentary materials consisting of lacustrine deposits, alluvial material and aeolian sediments have been deposited in the topographic lows between the basalt flows. These now form laterally discontinuous sedimentary interbeds, which, in turn, are overlain by the next generation of basalt flows (Anderson and Lewis, 1989; Barraclough et al., 1976; Schaefer and Kattenhorn, 2004; Smith, 2004).

The margins of basalt flows are commonly highly fractured and rubbly giving rise to high permeability zones of rubble, fractures, and clinker collectively known as either rubble zones (e.g., Nimmo et al., 2004b; Smith, 2004) or interflow zones (e.g., Ackerman, 1991). Rubble zones are found between 5-20\% of the basalt flows and have hydraulic conductivities on the order of $800 \mathrm{~m} /$ day or higher (Nimmo et al., 2004b). Rubble zones in contact with a low-permeability feature such as massive basalt or a sedimentary interbed may host significant perched aquifers and facilitate lateral flow for distances on the order of 100s to 1000s of meters (Nimmo et al., 2002). Nimmo et al. (2004b) point out that observed rapid lateral transport rates over distances of $1000 \mathrm{~m}$ or more indicate that rubble zones may exhibit large-scale continuity under some conditions. 


\section{Conceptual model of flow and transport in the ESRP vadose zone}

Over the past ten years, three tracer tests of note have been performed in the variablysaturated, fractured basalt and interlayered sediments of the ESRP. In chronological order, these consist of the Large Scale Infiltration Test (LSIT) carried out in 1994 (Newman and Dunnivant, 1995; Wood and Norrell, 1996), the Box Canyon tests carried out in 1996 and 1997 (Doughty, 2000; Faybishenko et al., 2000) and the Spreading Area test carried out in 1999 (Nimmo et al., 2002). Each of these tests was intended to investigate flow and transport in the vadose zone of the ESRP at a different scale. The LSIT provided information on the 100s of meters scale, the Box Canyon tests concentrated on flow and transport within a single basalt flow (scale of several meters) and the Spreading Area test provided information on the 100 s to 1000 s of meters scale.

The Large Scale Infiltration Test (LSIT) was carried out in a $26,000 \mathrm{~m}^{2}$ infiltration pond at the Radioactive Waste Management Complex at INL (see Fig. 1 for location of RWMC). The pond was flooded for six days and then a conservative tracer, Se-75 was added to the pond, after which flow was continued for another 30 days. One hundred and one monitoring wells and lysimeters were installed in and around the pond in three concentric rings. Water was collected at 30 of the 101 monitoring points and tracer was detected at 26 of these sites. No water was recovered from any well or lysimeter outside the footprint of the pond except at a depth of $70 \mathrm{~m}$ where a sedimentary interbed caused perching and lateral flow. One of the most important findings of this test was that infiltration through the unsaturated basalt is essentially vertical until intercepted by an interbed at which point perching and lateral flow occur. In addition, application of the 
one-dimensional advection-dispersion equation to breakthrough data from the LSIT provided estimates of flow velocity (v) and longitudinal dispersivity $(\alpha)$ for the unsaturated basalt (mean $\mathrm{v}=1.01 \mathrm{~m} / \mathrm{day}$; range of $\alpha=0.18 \mathrm{~m}$ to $3.92 \mathrm{~m}$ ) and along the interbed (mean $\mathrm{v}=5.02 \mathrm{~m} /$ day; range of $\alpha=0.10 \mathrm{~m}$ to $45.80 \mathrm{~m}$ ) (Dunnivant et al., 1998).

Faybishenko and coworkers carried out five infiltration tracer tests at Box Canyon near INL in 1996 and 1997 (Faybishenko et al., 2000). These were relatively shortduration tests (two days to two weeks) designed to explore flow and transport within a single basalt flow. Faybishenko et al. (2000) concluded from the location of tracer detections that solutes moved rapidly through preferential flow pathways. They identified column-bounding fractures as the primary conduit for flow between the surface and the lower boundary of the basalt flow under investigation. The authors concluded that water flowed rapidly through saturated fractures and that the surrounding matrix saturated slowly (on the order of days) as long as there was water in the fracture. Finally, they pointed out that some fractures that were initially wet drained after the beginning of the test, despite the fact that infiltration from the surface had reached a steady rate. The conceptual model of Faybishenko et al. (2000) identified a variety of mass transport mechanisms based both on geology and on distribution of saturation. These mechanisms include: (1) fracture-to-matrix diffusion, (2) vesicular basalt-to-massive basalt diffusion, (3) preferential flow through conductive fractures and the effect of funneling, (4) vesicular basalt-to-nonconductive fracture diffusion, (5) conductive fracture-to-vesicular basalt flow and diffusion, (6) lateral flow and advective transport in the central fracture zone, (7) lateral flow and advective transport in the rubble zone, and (8) flow into the underlying basalt (see Fig. 17 in Faybishenko et al., 2000). 
The Spreading Area test of Nimmo et al. (2002) was conducted using large flood control ponds located $\sim 10 \mathrm{~km}$ upstream of the VZRP on the Big Lost River at INL. Nimmo and coworkers placed a total of $675 \mathrm{~kg}$ of the conservative tracer, 1,5naphthalene disulfonate, into two flooded spreading areas. A network of monitoring wells was used to sample water from perched zones 100 s to 1000 s of meters from the spreading areas. Tracer recovery results indicated that within nine days water moved from the spreading areas vertically to the aquifer. In less than four months tracer was transported laterally along perched layers for distances up to $1.3 \mathrm{~km}$. From these observations the authors concluded that although low permeability layers divert water laterally they do not prevent solute transport to the aquifer. They also noted that horizontal flow probably occurs under essentially saturated conditions at rates as high as $14 \mathrm{~m} /$ day. In a follow-up study Nimmo et al. (2004a) proposed that horizontal flow through saturated high-permeability zones in the basalt associated with laterally continuous interbeds may be described as Darcian flow.

Based on the three studies outlined above, together with data from long-term monitoring at INL, (Anderson and Lewis, 1989; Barraclough et al., 1976; Mattson et al., 2004; Rightmire and Lewis, 1987) a conceptual model has been developed. The major components of this conceptual model are:

1. Water moves mostly vertically through the basalt until it reaches a geologic contact or other area of strong permeability contrast that diverts water laterally.

2. Percolation through the fractured basalt occurs primarily in column-bounding fractures; however, these fractures do not necessarily remain wet but rather fill and empty with time even when infiltration has reached a steady rate. 
3. During percolation through a previously dry subsurface the basalt matrix is initially unsaturated but saturates gradually as long as the bounding fractures contain water.

4. Diffusive mass transport between mobile and immobile fluid domains is thought to be an important transport mechanism in the fractured basalt but matrix diffusion has not been quantified.

5. Sedimentary interbeds act to slow downward flow, causing perched saturated zones and lateral flow.

6. Under saturated or near-saturated conditions, flow along the interbeds is facilitated by the combination of a low permeability layer (the sediments of the interbed and clay-rich fracture fill in the associated basalt) overlain by a high permeability basalt rubble zone that acts to conduct water laterally. Flow is thought to take place through the rubble zone under saturated or nearly saturated conditions.

7. Although the interbeds divert flow laterally, water and solutes eventually move downward. An important outstanding question is whether water moves through the sedimentary interbeds primarily through the matrix or via preferential flow paths.

\section{EXPERIMENTAL DESIGN AND METHODS}

\section{Description of the Vadose Zone Research Park (VZRP)}

The VZRP is a one-square-mile facility located in the southwestern portion of INL along the Big Lost River. The Big Lost River is an intermittent stream that flows from the Pioneer Mountains to the west, enters INL and then turns north to a series of sinks and playas where it terminates. A network of monitoring wells and instrumented 
boreholes surrounds two percolation ponds and extends some $1000 \mathrm{~m}$ north to the Big Lost River. The two roughly square percolation ponds are immediately adjacent to one another and each measure approximately $76 \mathrm{~m}$ on an edge (Fig. 2). The primary function of the ponds is to dispose of uncontaminated wastewater generated by the Idaho Nuclear Technology and Engineering Center (INTEC), which lies approximately $4 \mathrm{~km}$ to the northeast of the VZRP. The INTEC diverts an average of 3800 to $5700 \mathrm{~m}^{3}\left(\sim 1.0 \times 10^{6}\right.$ to $1.5 \times 10^{6}$ gal.) of water to one or the other of the ponds daily. This water is pumped from an aquifer well near the INTEC, softened using an ion exchange resin, and circulated through the facility prior to disposal at the VZRP.

At the VZRP (Fig. 3), the surficial alluvium is approximately $15 \mathrm{~m}$ thick, and consists of alluvial gravels, pebbles, and cobbles mixed with fine-grained silty and clayey sand (Smith, 2004). Below the surficial alluvium lie multiple layers of basalt and interbedded sediments. The monitoring network at the VZRP is focused largely within the $25 \mathrm{~m}$ of basalt that lies between the alluvium and a sedimentary interbed at approximately $40 \mathrm{~m}$ depth. This interbed is relatively continuous beneath the VZRP, has an average thickness of $\sim 5 \mathrm{~m}$ and is known as the C-D interbed because it lies between the $\mathrm{C}$ and $\mathrm{D}$ basalt units (Baker et al., 2004). Although the alluvium/basalt contact and the contact between the basalt and the C-D interbed are the focus of this study, inspection of the well logs from the VZRP indicates that there are many smaller, less continuous sediment and clay layers and lenses interspersed throughout the basalt. The hydrogeology of the VZRP is representative of the vadose zone throughout INL and the ESRP. As a result, although this study was carried out on a local scale, the results are applicable to the much larger, regional scale. Furthermore, the hydrogeologic setting of a thick vadose zone with 


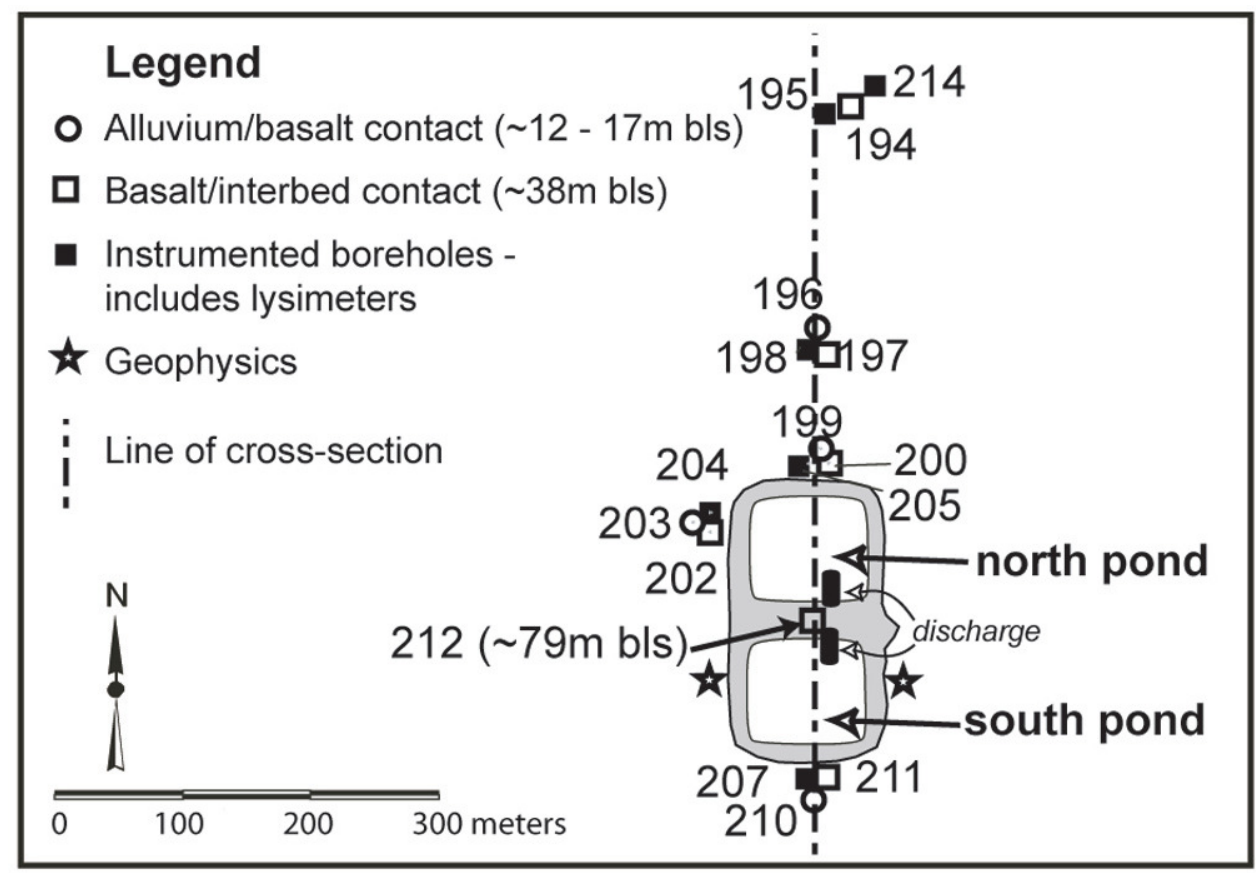

Figure 2: Map of infiltration ponds and associated near-field monitoring network at the Vadose Zone Research Park (VZRP).

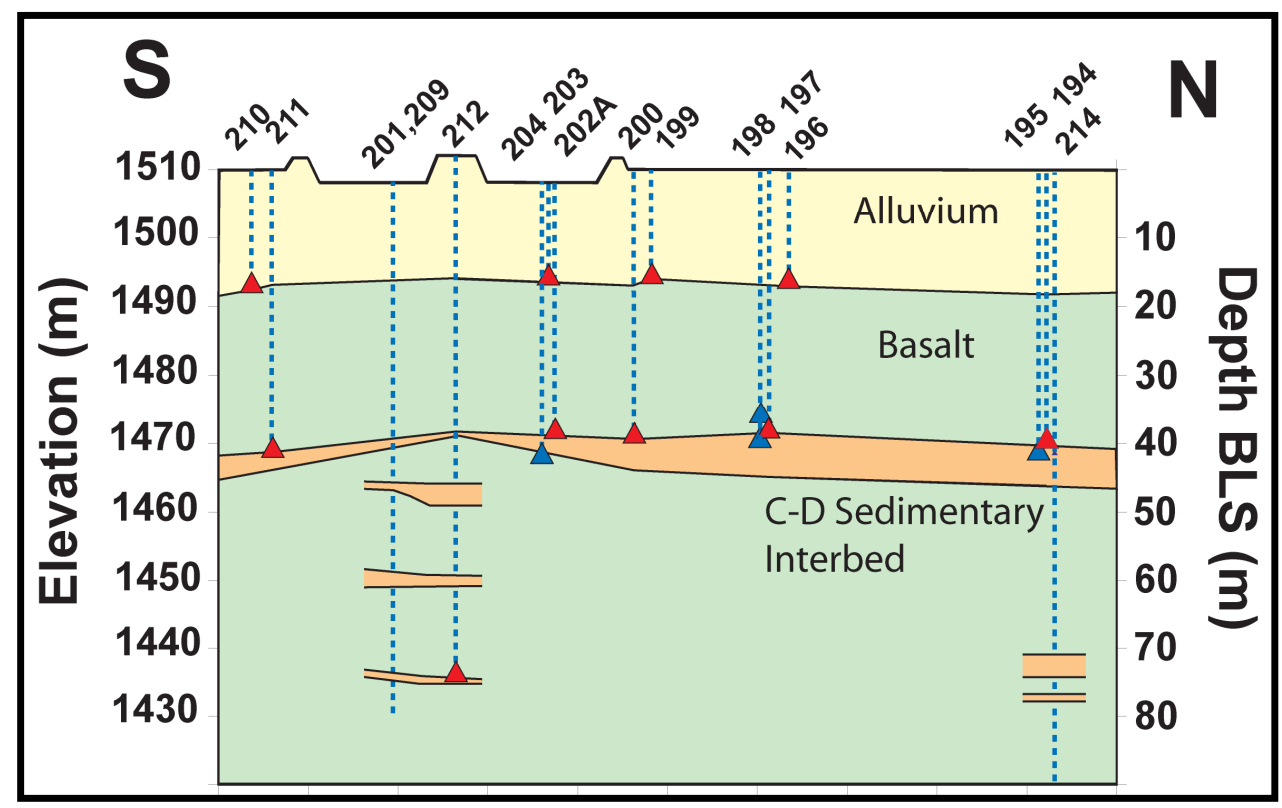

Figure 3: Schematic cross-section showing lithology and monitoring network along the line of section shown in Fig. 2. Wells 202, 203(A), and 204 are projected into the line of section. Red symbols represent monitoring wells; blue symbols represent suction lysimeters 
layers of geologic material of strongly contrasting permeabilities is typical of many arid and semiarid regions.

Thirty-nine wells and instrumented boreholes are located around the percolation ponds and in a line northward to the Big Lost River. Wells and boreholes are distributed in nested sets (Fig. 2 and 3). Each set consists of a shallow monitoring well completed at the alluvium/basalt contact ( 15-20 m below land surface (bls)), a deeper monitoring well completed at the C-D interbed ( $40 \mathrm{~m}$ bls), and an instrumented borehole containing tensiometers, suction lysimeters, gas ports, water content sensors, and thermocouples located at various depths. In this paper each well or lysimeter identifier is followed by a letter in parentheses to indicate where the well is completed or the lysimeter is located. This letter (A) is for wells at the base of the alluvium, (B) for the lysimeter that is finished in the basalt and the wells at the contact between the basalt and the C-D interbed, and (I) for suction lysimeters within the C-D interbed. Well 202 collapsed during drilling and a second hole was drilled and named well 202A; in this paper this well appears as well 202A(B). Identifiers of all other wells and lysimeters consist only of the relevant number and a letter in parentheses e.g., well 210(A), well 211(B), and lysimeter 204129(I).

Prior to infiltration from the ponds, the subsurface below the VZRP was relatively dry with only a few areas of local saturation. Initial moisture content analyses were carried out at the U. S. Geological Survey Unsaturated-Zone Flow (UZF) laboratory in Menlo Park, CA (Winfield, 2003). Moisture content was determined gravimetrically on ten interbed sediment samples taken from seven boreholes at depths ranging from $\sim 40 \mathrm{~m}$ to $\sim 60 \mathrm{~m}$. The majority of the samples were less than 50\% saturated (volumetric water 
content $<0.2$ ), an exception being two saturated samples collected from the C-D interbed (Winfield, 2002). Similarly, the basalt was largely unsaturated although locally perched water occurred both within the basalt and at the contact between the basalt and the C-D interbed (Baker et al., 2004). In order to test the water delivery system between INTEC and the VZRP, approximately $10,000 \mathrm{~m}^{3}$ of water were discharged between June 18 and June 27, 2002. About $10 \%$ of this water was released to the north pond and the remainder to the south pond. High-volume discharge ( 3800 to $5700 \mathrm{~m}^{3} /$ day) began in the south pond August 27, 2002, switched to the north pond September 21, 2002 and then back to the south pond October 5, 2002. The discharge continued to the south pond until June 31, 2003 and then was switched to the north pond coincident with the start of the second tracer test of this study (Baker et al., 2004). While we did not quantify the initial spatial distribution of moisture beneath the north pond at the start of the second tracer test there clearly would have been a decaying south-to-north lateral gradient in both the alluvium and the basalt due to infiltration from the south pond. This gradient could have initially diverted tracers to the north more than they otherwise would have been if there had not been an initial water mound beneath the south pond. However, we know that saturated conditions did not exist at the base of the alluvium on the north side of the north pond during infiltration into the south pond, and we also know that the mound in the alluvium beneath the south pond decayed in $\sim 4$ days. Perched water levels at the base of the basalt never exceeded $\sim 5.5 \mathrm{~m}$ at the periphery of the south pond (in well 211(B)) so the majority of the basalt thickness beneath the south pond remained unsaturated. Thus, the residual effects from the south pond infiltration on test 2 were limited both spatially and temporally. 


\section{Field Experiments to Characterize Water and Solute Movement}

Two tracer tests were carried out at the VZRP in the summer of 2003. The first was conducted in the south pond starting June 11, 2003. At this time the INTEC had been discharging water to the south pond for roughly nine months. Local areas of saturation were present at the southern end of the alluvium/basalt contact but to the north and west the contact was unsaturated. Water was also perched along the C-D interbed with water levels between 3.0 and $5.5 \mathrm{~m}$ above the upper surface of the C-D interbed at the location of the wells. Based on water level data from the wells, the flow system was considered to be at quasi-steady state. Maximum water level fluctuations were on the order of 0.04 $\mathrm{m} /$ day and could be related to changes in the rate at which water was being discharged to the pond. Approximately $18.25 \mathrm{~kg}$ of 2,4,5-trifluorobenzoate $(2,4,5$-TFBA) was used as a conservative tracer. The 2,4,5-TFBA was "injected" by emptying tracer-containing carboys into the inflow of the south pond. For two hours subsequent to the injection, grab samples were collected every 15 minutes at four locations around the pond.

The second tracer test differed fundamentally from the first test in that the system was relatively dry prior to the beginning of the test. Test 2 was conducted in the north pond which had not received discharge water for nine months except for 14 days between September 21, 2002 and October 5, 2002. Two conservative tracers were used in this test; bromide ion (Br-) and 2,4-difluorobenzoate (2,4-DFBA). The tracers (16.8 kg Br and $21.6 \mathrm{~kg}$ 2,4-DFBA) were mixed in a tank ( $1600 \mathrm{~L})$, which was located on the berm between the two ponds. On July 31, 2003 the discharge was switched from the south 
pond to the north pond, and the tracer mixture was added with the first water into a shallow pit in the floor of the north pond. The tracer was chased by continuous discharge to the north pond for the next several months.

After the first tracer addition (test 1), all the wells and lysimeters that yielded water were sampled every two to four hours for two weeks. The test 2 sampling period was longer with samples collected every three to four hours for a month and then less frequently for several more months. The characteristics of the wells and lysimeters that received water and were sampled during the two tracer tests are summarized in Table 1 (see Fig. 2 and 3 for locations). If possible, the wells were purged of three bore volumes prior to sampling. Due to transient flow conditions during test 2, some wells were pumped to dryness before three bore volumes were obtained. When this happened the wells were allowed to recover for 5-15 minutes and then sampled. The alluvial wells to the north and north-west of the north pond (199(A) and 203(A)) were dry at the beginning of test 2 . These wells were bailed until enough water was present to allow pumping. Samples were filtered using a $0.45 \mu \mathrm{m}$ in-line filter. Suction lysimeters were purged with argon to remove all the water present at each sampling cycle and samples were filtered using $0.45 \mu \mathrm{m}$ nylon syringe filters. Between sampling events a vacuum tank at the surface was connected to each of the suction lysimeters via tubing in the borehole and the lysimeters were placed under negative pressure to enhance flow from the surrounding unsaturated media into the ceramic sampling cups (Baker et al., 2004).

Tracer samples were returned to Los Alamos National Laboratory for analysis. Samples were analyzed for fluorobenzoates (FBAs) using high-performance liquid chromatography with UV absorbance detection and for Br using ion chromatography 


\begin{tabular}{|c|c|c|c|c|}
\hline $\begin{array}{l}\text { Well/Lysimeter } \\
\text { Identifier }\end{array}$ & Location & $\begin{array}{c}\text { Radial } \\
\text { distance } \\
\text { from well } \\
212(\mathrm{~m})\end{array}$ & $\begin{array}{c}\text { Completion } \\
\text { depth b.l.s. (m) }\end{array}$ & Completion lithology \\
\hline Well 199(A) & $\mathrm{N}$ of $\mathrm{N}$ pond & 142 & 15.5 & alluv/basalt contact \\
\hline Well 203(A) & $\begin{array}{l}\mathrm{NW} \text { of } \mathrm{N} \\
\text { pond }\end{array}$ & 120 & 15.8 & alluv/basalt contact \\
\hline Well 210(A) & S of $S$ pond & 142 & 18.1 & alluv/basalt contact \\
\hline Well 197(B) & $\begin{array}{c}\text { Far } \mathrm{N} \text { of } \mathrm{N} \\
\text { pond }\end{array}$ & 215 & 38.1 & top C-D interbed \\
\hline Well 200(B) & $\mathrm{N}$ of $\mathrm{N}$ pond & 129 & 38.7 & top C-D interbed \\
\hline Well 202A(B) & $\begin{array}{c}\mathrm{NW} \text { of } \mathrm{N} \\
\text { pond }\end{array}$ & 107 & 37.4 & top C-D interbed \\
\hline Well 211(B) & $S$ of $S$ pond & 133 & 39.0 & top C-D interbed \\
\hline Well 212 & $\begin{array}{c}\text { Between } \\
\text { ponds }\end{array}$ & 0 & 79.2 & deep basalt/interbed \\
\hline Lys 198114(B) & $\begin{array}{l}\text { Far } \mathrm{N} \text { of } \mathrm{N} \\
\text { pond }\end{array}$ & 215 & 34.7 & $\begin{array}{l}\text { fractured basalt } \sim 3 \mathrm{~m} \\
\text { above C-D interbed }\end{array}$ \\
\hline Lys 198126(I) & $\begin{array}{c}\text { Far } \mathrm{N} \text { of } \mathrm{N} \\
\text { pond }\end{array}$ & 215 & 38.4 & within C-D interbed \\
\hline Lys 204129(I) & $\begin{array}{l}\mathrm{NW} \text { of } \mathrm{N} \\
\text { pond }\end{array}$ & 120 & 39.3 & below C-D interbed \\
\hline
\end{tabular}

Table 1: Descriptions of wells and lysimeters that received water during tests 1 and 2 . Well and lysimeter numbers correspond with locations shown in Figures 2 and 3. Letters in parentheses indicate where a well is completed or a lysimeter is located; $A=$ alluvium/basalt contact, $B=$ basalt/interbed contact, and $I=$ within the $C$-D interbed. Well 212 is a deeper well and has no associated letter.

with conductivity detection. The quantification limit (QL) for $\mathrm{Br}$ and for 2,4-DFBA was $0.016 \mathrm{mg} / \mathrm{L}$. There are two QLs shown for 2,4,5-TFBA; the samples from test 1 were run using a method with a QL of $0.008 \mathrm{mg} / \mathrm{L}$, whereas the 2,4,5-TFBA analyses in samples that also contained 2,4-DFBA from test 2 had a QL of $0.024 \mathrm{mg} / \mathrm{L}$. In some of the FBA plots (Fig. 4), data below the quantification limit are shown; these data are included to provide a visual continuation of the BTC and should not be considered to be quantitative. Only the FBA data are presented in this paper. 


\section{TRACER TEST AND MODEL RESULTS}

\section{Breakthrough curves}

Collection of grab samples after introduction of tracer to the south pond (Test 1) enabled coarse mapping of the spatial distribution of the tracer during infiltration. Tracer concentrations were highest in the northern third of the pond adjacent to the injection point. In the south-eastern part of the pond tracer concentrations were approximately one-third of those toward the north. The south-western quadrant remained dry throughout the test. Tracer concentration in all portions of the pond dropped below the quantification limit (16 ppb) within the first two hours after tracer was introduced to the pond.

The tracer tests yielded breakthrough curves (BTCs) that provided information regarding transport through the alluvium, the alluvium/basalt complex, and the C-D interbed for a range of vertical and lateral distances (Fig. 4). Test 1 data represent travel under quasi-steady-state flow conditions with considerable antecedent wetness. In contrast, the second tracer test BTCs represent transport under transient flow conditions arising from infiltration into an initially dry shallow system with relatively wet conditions at the contact between the basalt and the C-D interbed. Initial and peak arrival times together with peak tracer concentrations are summarized in Table 2. 


\section{Estimated flow velocities}

The breakthrough curves generated at the VZRP were fitted using the onedimensional advection-dispersion equation (1-D ADE) to yield estimates of flow velocity (v) for the alluvium, the integrated alluvium/basalt complex, and the C-D interbed (Table

3). The CXTFIT code (Parker and van Genuchten, 1984; Toride et al., 1999) was used to fit breakthrough data with analytical solutions to the deterministic, equilibrium ADE:

$$
\frac{\partial C}{\partial t}=\left(\frac{1}{\theta}\right) \frac{\partial}{\partial x}\left(D_{L}(\theta) \frac{\partial C}{\partial x}\right)-v(\theta) \frac{\partial C}{\partial x}
$$

Where:

C solute concentration $(\mathrm{mg} / \mathrm{L})$

$\mathrm{D}_{\mathrm{L}} \quad$ longitudinal dispersion coefficient $\left(\mathrm{m}^{2} /\right.$ day)

$\mathrm{v} \quad$ average pore water velocity

$\theta \quad$ volumetric water content

t time (days)

X transport distance $(\mathrm{m})$

The purpose of this modeling was to determine average flow velocities through different portions of the profile. For this exercise the volumetric water content within each unit was assumed to be constant and equation (1) above was simplified to: 
$\frac{\partial C}{\partial t}=D_{L} \frac{\partial^{2} C}{\partial x^{2}}-v \frac{\partial C}{\partial x}$

This equation describes transport of a non-reactive solute through a homogeneous porous medium under steady-state flow conditions. The initial and boundary conditions utilized in this study are:

$$
\begin{array}{ll}
\mathrm{C}(\mathrm{x}, 0)=0, & \mathrm{x} \geq 0 \\
\mathrm{C}(0, \mathrm{t})=\mathrm{C}_{0}, & 0<\mathrm{t} \leq \mathrm{t}_{0} \\
\mathrm{C}(0, \mathrm{t})=0, \quad \mathrm{t}>\mathrm{t}_{0} \\
\frac{\partial C}{\partial x}(\infty, t)=0, \quad \mathrm{t} \geq 0
\end{array}
$$

Initial time $\left(\mathrm{t}_{0}\right)$ is the time at which tracer was added to the system (and, for test 2 , the time at which flow to the north pond was initiated). Tracer transport distance (x) is the sum of the horizontal and vertical components of flow (see below for further discussion). The constant-concentration boundary condition was used despite the decreasing concentration over the two hours that it took for tracer to infiltrate from the surface. We consider the error introduced by this departure from the defined boundary condition to be negligible because the rise and fall in concentration was relatively steep and the total infiltration time ( $\sim 2$ hours) was short relative to the transport times (days to weeks). Thus, the injection approximated a pulse input. Total mass was included as a fitting parameter in the estimation procedure because the solute mass entering any given subset 


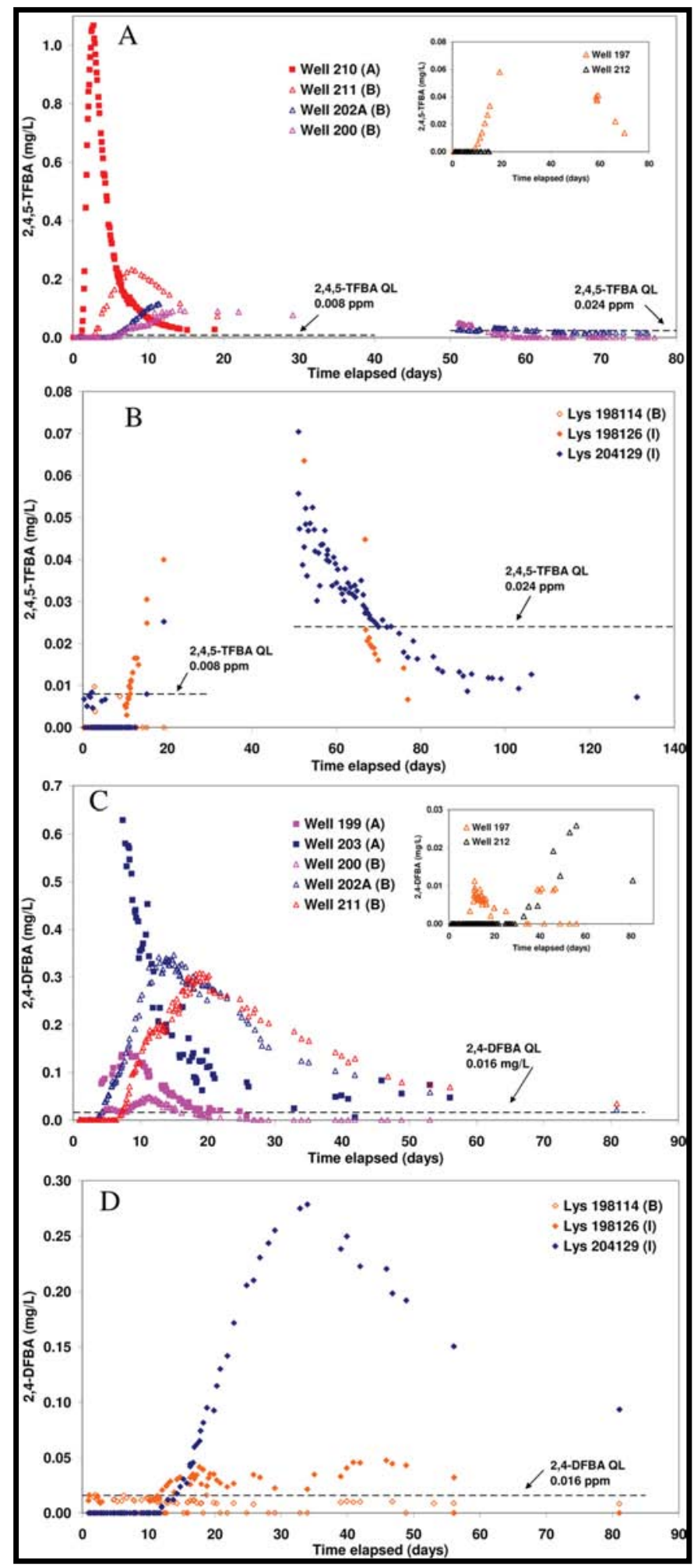

Figure 4: Test 1 and 2 breakthrough curves from wells and lysimeters $(Q L=$ quantification limit). A: Test 1 wells; B: Test 1 lysimeters; C: Test 2 wells; D: Test 2 lysimeters 


\begin{tabular}{|c|c|c|c|}
\hline \multicolumn{4}{|c|}{ TEST 1} \\
\hline Well ID & $\begin{array}{l}\text { first arrival } \\
\text { (days) }\end{array}$ & $\begin{array}{c}\text { peak arrival } \\
\text { (days) }\end{array}$ & $\begin{array}{c}\text { peak } 2,4,5-\mathrm{TFBA} \\
\text { concentration }(\mathrm{mg} / \mathrm{L})\end{array}$ \\
\hline 210(A) & 1 & 2.7 & 1.1 \\
\hline 197(B) & 9 & N/A & N/A \\
\hline $200(\mathbf{B})$ & 5 & 14 & 0.1 \\
\hline $202 A(B)$ & 5 & 12 & 0.12 \\
\hline 211(B) & 3 & 8 & 0.25 \\
\hline 212 & $29 \dagger$ & N/A & N/A \\
\hline \multicolumn{4}{|l|}{ Lysimeter ID } \\
\hline 198114(B) & 27 & N/A & N/A \\
\hline 198126(I) & 21 & $35+\neq$ & N/A \\
\hline 204129(I) & 19 & $20-50$ & N/A \\
\hline \multicolumn{4}{|c|}{ TEST 2} \\
\hline Well ID & $\begin{array}{l}\text { first arrival } \\
\text { (days) }\end{array}$ & $\begin{array}{c}\text { peak arrival } \\
\text { (days) }\end{array}$ & $\begin{array}{l}\text { peak 2,4-DFBA concentration } \\
(\mathrm{mg} / \mathrm{L})\end{array}$ \\
\hline 199(A) & $4 \#$ & 8 & 0.14 \\
\hline 203(A) & $6 \dagger \dagger$ & $6-7 \ddagger$ & $>0.63$ \\
\hline $\begin{array}{c}\text { 197(B) peak } \\
1 \S\end{array}$ & N/A & $10-20$ & 0.011 \\
\hline 197(B) peak 2 & N/A & $40-50$ & 0.009 \\
\hline $\begin{array}{l}\text { 200(B) peak } \\
1 \text { 1] }\end{array}$ & 3 & 5 & 0.025 \\
\hline $200($ B) peak 2 & N/A & 11 & 0.05 \\
\hline $202 A(B)$ & 4 & 14 & 0.35 \\
\hline 211(B) & 7 & 19 & 0.31 \\
\hline 212 & 46 & N/A & N/A \\
\hline \multicolumn{4}{|l|}{ Lysimeter ID } \\
\hline 198114(B) & 27 & N/A & N/A \\
\hline 198126(I) & 17 & N/A & N/A \\
\hline 204129(I) & 12 & 34 & 0.28 \\
\hline
\end{tabular}

Table 2: Summary of breakthrough behavior in tests 1 and 2

$\begin{array}{ll}\dagger & \text { First arrival based on three data points all below QL } \\ + & \text { Peak arrival estimated from BTC slope } \\ \S & \text { All 2,4-DFBA data below QL, BTC bimodal } \\ \text { II } & \text { Well 200(B) BTC bimodal--presented in two peaks } \\ \# & \text { First arrival based on water level data in well (Baker) } \\ \dagger \dagger & \text { First arrival based on water level data in well (Baker) } \\ +\dagger & \text { From interpolation between available data } \\ \text { N/A } & \text { Data not available }\end{array}$




\begin{tabular}{|c|c|c|c|c|}
\hline $\begin{array}{c}\text { Well } \\
\text { identifier }\end{array}$ & Domain sampled & $\begin{array}{c}\text { Travel } \\
\text { distance } \\
(\mathbf{m}) \dagger\end{array}$ & $\begin{array}{c}\mathbf{v} \\
(\mathbf{m} / \mathbf{d a y})\end{array}$ & $\begin{array}{c}\mathbf{R}^{2} \\
\text { (coefficient of } \\
\text { determination) }\end{array}$ \\
\hline \multicolumn{5}{|c|}{ TEST 1} \\
\hline \multirow[t]{2}{*}{$210(\mathrm{~A})$} & $\begin{array}{l}\text { Alluvium } \\
\text { MAX }\end{array}$ & 145 & 41 & 0.975 \\
\hline & MIN & 85 & 24 & 0.975 \\
\hline \multirow[t]{2}{*}{$202 \mathrm{~A}(\mathrm{~B})$} & $\begin{array}{l}\text { Alluvium/basalt } \\
\text { MAX }\end{array}$ & 166 & 8 & 0.971 \\
\hline & MIN & 124 & 6 & 0.971 \\
\hline \multirow[t]{2}{*}{ 211(B) } & $\begin{array}{l}\text { Alluvium/basalt } \\
\text { MAX }\end{array}$ & 157 & 13 & 0.996 \\
\hline & MIN & 97 & 8 & 0.996 \\
\hline \multicolumn{5}{|c|}{ TEST 2} \\
\hline 199(A) & Alluvium & 136 & 13 & 0.955 \\
\hline 200(B) pk 1 & Alluvium/basalt & 129 & 20 & 0.858 \\
\hline 200 (B) $p k 2$ & Alluvium/basalt & 129 & 10 & 0.939 \\
\hline $202 \mathrm{~A}(\mathrm{~B})$ & Alluvium/basalt & 131 & 5 & 0.981 \\
\hline 211(B) & Alluvium/basalt & 194 & 6 & 0.960 \\
\hline $\begin{array}{l}\text { Lys } \\
204129(\mathrm{I})\end{array}$ & $\begin{array}{l}\text { Alluvium/basalt/ } \\
\text { interbed }\end{array}$ & 146 & 3 & 0.980 \\
\hline
\end{tabular}

Table 3: Summary of flow velocities for both tracer tests.

$\dagger$ See text for travel distance calculation

of flow pathways was not known. The only other parameters optimized were flow velocity $(v)$ and dispersion coefficient $\left(D_{L}\right)$. The analytical model utilized in this work does not explicitly account for the complexity of transport through a geologically heterogeneous and variably-saturated system. However, the model fits to the first arrival and peak portions of the BTCs are very good (Fig. 5), suggesting that that although the geometry and flow conditions are over-simplified, the model provides reasonable overall estimates of average flow velocities in the system. In this paper, we use the estimates of 
flow velocities generated using the 1-D ADE to provide information on relative flow and transport between lithologic units under varying infiltration conditions. Dispersion coefficients are not reported as they are particularly sensitive to the fact that the test boundary conditions together with the transient, three-dimensional nature of the flow system violate many of the assumptions inherent in the 1-D ADE.

In order to determine transport velocities, travel distances must be estimated. In test 1 , tracer was added to the south pond and is known to have distributed unevenly across the wetted area of the pond. On the basis of tracer concentrations measured in the pond and visual estimates of pond water volume, we assumed that most of the tracer mass infiltrated between the southern-eastern part of the pond, where water volume was greatest and near the discharge, where tracer concentrations were greatest. We recognize that due to the spreading of the tracer across the pond, possible travel distances encompass a wide range. In order to provide bounding estimates of flow velocity, model fits were carried out assuming two infiltration points, one in the southern part of the south pond and one at the discharge to the south pond. Maximum and minimum linear transport distances were calculated as the sum of the horizontal distance from each of these infiltration points to a given sampling location plus the depth to that sampling location. Three test 1 BTCs were fitted; one (well 210(A)) provides transport parameters for the alluvium and two (wells 202A(B) and 211(B)) provide transport parameters for the integrated alluvium/basalt complex (Table 3). Model fits of a representative alluvial well (210(A)) and deeper well (211(B)) are shown in Fig. 5. 

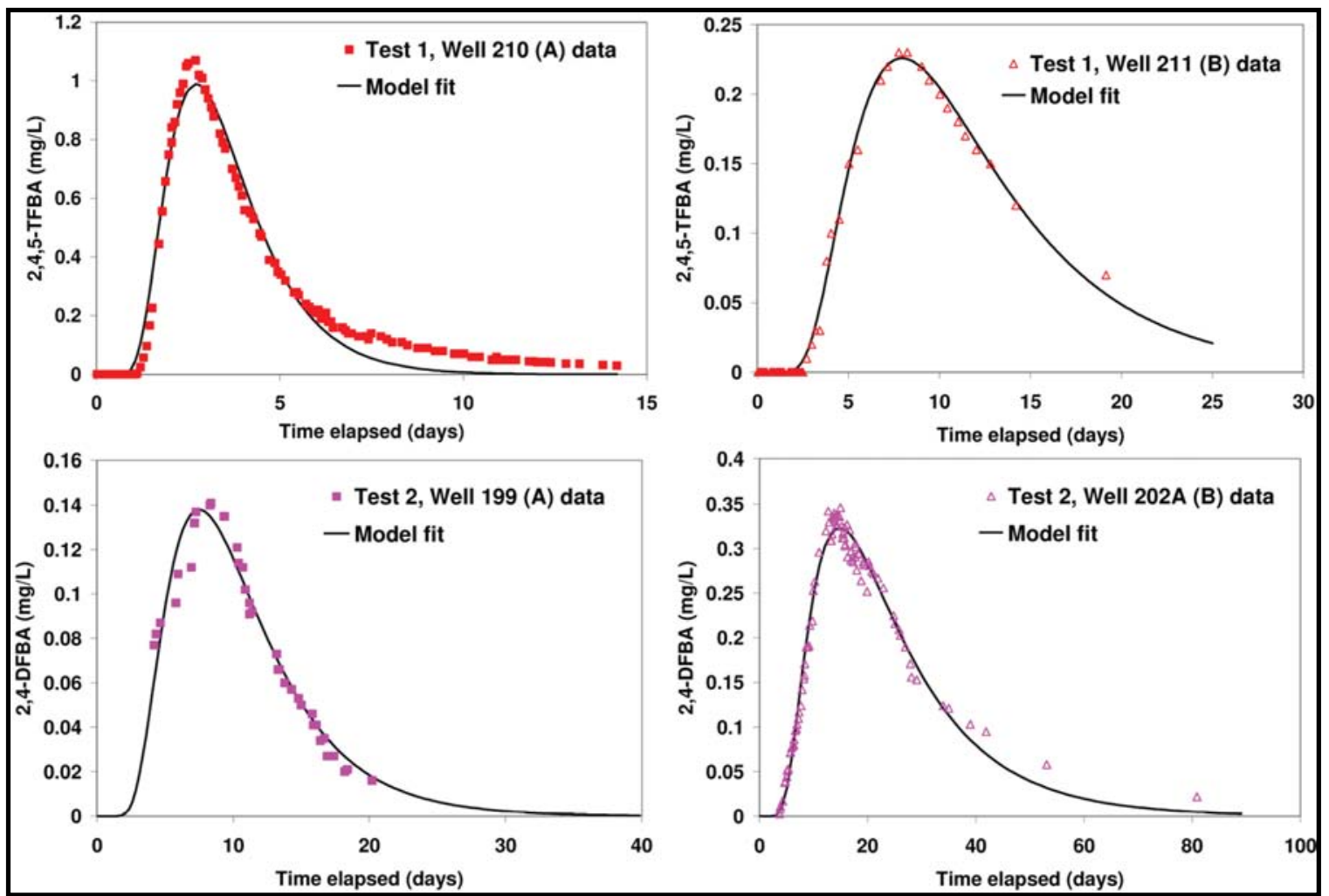

Figure 5: Representative fits of test 1 and test 2 data from which flow velocity estimates where generated. See Table 3 for minimum and maximum transport distances used in these simulations.

The estimated minimum and maximum flow velocities yielded by well 210(A) are 24 and $40 \mathrm{~m} /$ day respectively. These velocities are integrated values for transport from the ponded water at the surface, down through the alluvium, and along the alluvium/basalt contact to the well. The minimum and maximum flow velocities estimated from BTCs in well 202A(B) are 6 and $10 \mathrm{~m} /$ day, and for well 211(B) are 8 and 13 m/day, respectively. In both cases these represent integrated velocity distributions from several sub-domains which include flow across the alluvium/basalt contact, through the variably-saturated basalt, and along the basalt/interbed contact. 
In test 2 , the tracer input was constrained to a shallow pool roughly $4 \mathrm{~m}$ in diameter within the north pond so the tracer input signal was considered to be a point source. Maximum linear transport distances were calculated as the sum of the horizontal distance from the center of the tracer pool to the well and the depth of the well. This method yields an estimated maximum travel distance and thus provides an upper bound on the average linear velocity. Test 2 yielded four breakthrough curves complete enough to be analyzed using CXTFIT; one alluvial well (well 199(A)) and three wells finished above the C-D interbed (wells 200(B), 202A(B), and 211(B)). Model fits of a representative alluvial well (199(A)) and deeper well (202A(B)) are shown in Fig. 5. Table 3 contains a summary of the velocity estimates from each BTC.

\section{DISCUSSION}

\section{Flow and transport through the surficial alluvium}

The alluvium at the VZRP, and throughout the ESRP, is known to be heterogeneous with gravel, sand and clay layers and lenses interspersed throughout (Smith, 2004). In such a system it is necessary to define a characteristic length scale below which the heterogeneity must be explicitly accounted for and above which effective properties (e.g. hydraulic conductivity) may be used to represent the system as a whole (Bear, 1972). According to the current conceptual model, flow through the surficial alluvium is expected to be largely vertical until the alluvium/basalt contact is reached and lateral spreading occurs. Flow pathways along the alluvium/basalt contact to the north and northwest are intercepted by two shallow wells (199(A) and 203(A)). In order to assess 
transport behavior through the alluvium at the scale of the tracer tests, a forward simulation was carried out using the tracer travel distance for well 203(A) during test 2 $(122 \mathrm{~m})$ together with the velocity and dispersion coefficient generated from an inverse fit of the test 2 well 199(A) BTC. The results of the forward simulation were compared with the BTC from well 203(A) (Fig. 6). The 1D-ADE with v and D from well 199(A) provides a reasonable estimate of the position of the peak and predicts all but the very late-time tailing behavior in well 203(A). The fact that one set of transport parameters describes breakthrough behavior in both wells suggests that, despite the known heterogeneity of the porous medium, comparable transport pathways through the alluvium formed to the north and the northwest. This in turn suggests that transport distances over $\sim 15 \mathrm{~m}$ vertically and $\sim 100 \mathrm{~m}$ laterally are greater than the characteristic

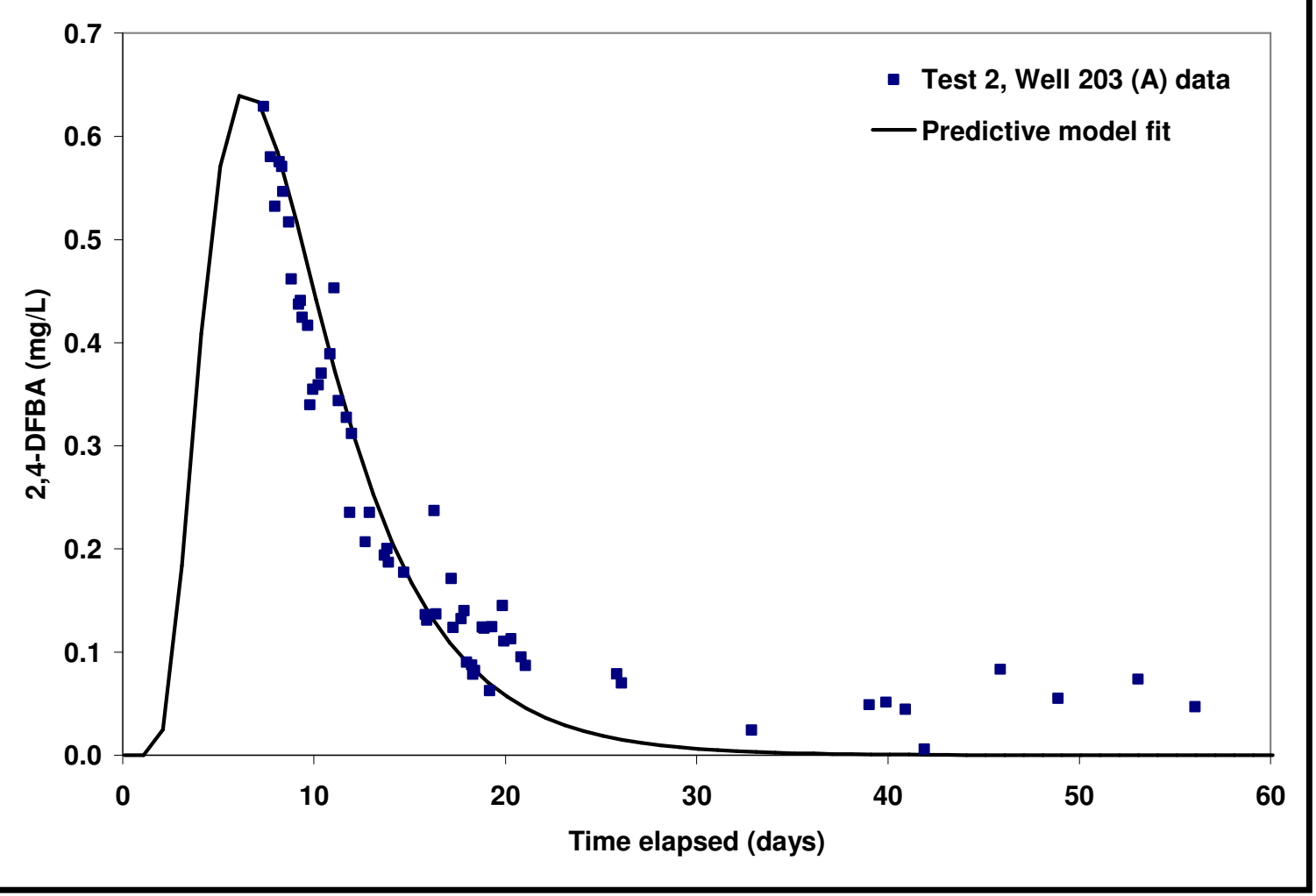

Figure 6: Prediction of test 2 well 203(A) data using parameters from an inverse fit of test 2 well 199(A) BTC. 
length for this medium.

\section{Flow and transport across the alluvium/basalt contact}

The behavior of the alluvial wells suggests that, although a saturated layer forms at the alluvium/basalt contact providing a mechanism for some horizontal transport, this perched layer is neither laterally extensive nor temporally persistent. In test 1 only well 210(A) at the south end of the south pond produced water; the other two alluvial wells (199(A) and 203(A)) were dry. When discharge was switched from the south pond to the north pond, well 210(A) dried up within 4 days and wells 199(A) and 203(A) began producing water within 4-6 days. Water never reached well 196(A), an alluvial well farther to the north of the north pond ( $228 \mathrm{~m}$ from well 212). This behavior strongly suggests that vertical flow across the alluvium/basalt contact is sufficiently large to limit the extent of lateral flow along the contact. In addition, significant tracer masses were recovered at the deeper wells in the same well clusters as the alluvial wells. Both of these observations are inconsistent with the alluvium/basalt contact acting as a lateral conduit to move a significant portion of the infiltrating water out of the monitoring domain of the VZRP. Rather, it appears that perched zones that form at the alluvium/basalt contact do not extend far beyond the margins of surface source and drain within days after the source of infiltration is removed. Other studies based on monitoring at both the RWMC and the INTEC support this conclusion (Cecil et al., 1991; Hull and Bishop, 2003). This result is important as it shows that perched water at the alluvium/basalt contact cannot store a large amount of water or solute, move water or solute over laterally extensive 
distances, or significantly retard the downward movement of water or potential contaminants.

\section{Flow and transport through the basalt}

The results of our tracer tests indicated that during high intensity infiltration from the surface into unsaturated basalt flow occurred primarily in the fractures. The fact that in test 2 three BTCs (wells 197(B) and 200(B) and lysimeter 198126(I); Fig. 4) are bimodal supports the idea that miscible displacement as conceptualized in porous media is not applicable to flow in the fractured basalt of the ESRP. The most plausible explanation for compound BTCs is that flow occurred along multiple flow paths with different flow lengths and/or flow velocities (Mohanty et al, 1998; Nimmo et al., 2002).

Flow velocities through the alluvium/basalt complex range from $\sim 5 \mathrm{~m} /$ day to $\sim 20$ $\mathrm{m} /$ day (Table 3). If flow was matrix-dominated we would expect flow velocities on the order of $0.4 \mathrm{~m} /$ day based on the laboratory measured mean vertical saturated hydraulic conductivity for ESRP basalt matrix $\left(\mathrm{K}_{\mathrm{sat}}=8.4 \times 10^{-2} \mathrm{~m} / \mathrm{day}\right.$; Bishop, 1992). The velocities observed in the field are 1-2 orders of magnitude greater than can be explained by matrix flow alone. We interpret the evidence of multiple flow paths, together with high flow velocities, as indicating that flow through the basalt occurred primarily in the fractures even when the matrix was unsaturated. 


\section{Flow and transport through the sedimentary interbeds}

The sedimentary interbeds in the ESRP vadose zone are thought to exert important controls on flow and transport, both physically and chemically. The formation of perched zones above the major sedimentary interbeds indicates that the interbeds act as barriers to vertical flow as well as facilitating lateral flow along the basalt/interbed contact (Newman and Dunnivant, 1995; Nimmo et al., 2002; Wood and Norrell, 1996). In current conceptual and numerical models of flow and transport in the ESRP vadose zone, sorption of contaminants is assumed to occur only within the surficial sediment and the sedimentary interbeds (Magnuson and Sondrup, 2006). Clearly the higher sorptive capabilities of these sediments may only be called upon if in fact flow patterns result in significant sediment/water interaction. Thus it is important to understand whether vertical flow occurs via percolation through the sedimentary material of the interbeds or if preferential flow paths such as high conductivity channels within the interbeds or interbed discontinuities result in significant bypassing of the interbed material.

By analyzing tracer BTCs collected above and below the C-D interbed, flow velocities were calculated for the sedimentary interbed and associated clay-filled, fractured basalt. The computed velocities were compared with velocities calculated from laboratory-derived sediment characteristics, the results of a water-balance calculation, and breakthrough behavior in a deep well at the VZRP in order to investigate the nature of flow through the interbed. Pore water pressure data from the tensiometer at $38.7 \mathrm{~m}$ in borehole 204 indicated that the C-D interbed saturated quickly in response to infiltration 
from the VZRP ponds and remained saturated during both tracer tests (Baker et al., 2004).

Figure 7 shows 2,4-DFBA breakthrough curves at well 202A(B) and lysimeter 204129(I). This well and lysimeter are in the same nested set located to the northwest of the northern VZRP pond. Well 202A(B) is completed in a basalt rubble zone just above the C-D interbed (the well is screened between 35.8 and $37.3 \mathrm{~m}$ bls and sedimentary interbed material was encountered at a depth of $37.5 \mathrm{~m}$ bls). Lysimeter 204129(I) is installed within the C-D interbed at a depth of $39.3 \mathrm{~m}$ bls. Given that the lateral flow distances from the tracer injection point to well 202A(B) and borehole 204 are similar

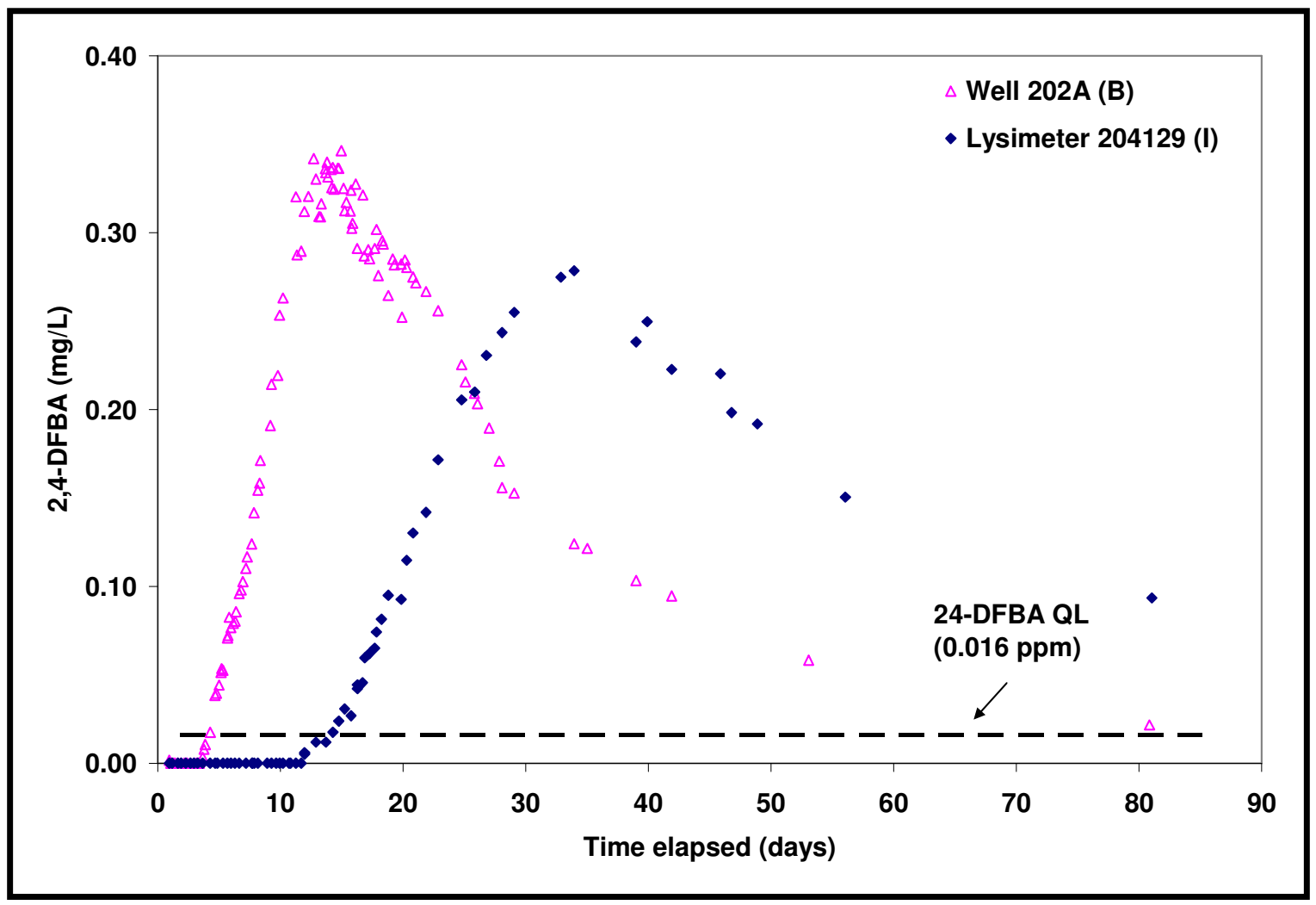

Figure 7: Test 2 breakthrough curves for well 202A(B) and lysimeter 204129(I).

(107 $\mathrm{m}$ and $120 \mathrm{~m}$ from well 212 respectively; see Table 1) the tracer breakthrough at well $202 \mathrm{~A}(\mathrm{~B})$ is assumed to be representative of the tracer arrival above the interbed in 
borehole 204. Thus, the distribution of tracer at 202A(B) was used as an input signal in order to fit the BTC at 204129(I) and calculate the flow velocity through the sedimentary interbed and clay-filled fractured basalt. This analysis yielded an estimated flow velocity of $0.12 \mathrm{~m} /$ day.

To address the question of whether preferential flow paths allow significant bypassing of the sedimentary interbeds it is informative to compare the hydraulic conductivity values derived from the results of inverse modeling with values calculated using laboratory hydraulic parameters. Comprehensive characterization of the VZRP interbed sediments has yielded estimates of saturated hydraulic conductivity $\left(\mathrm{K}_{\mathrm{sat}}\right)$ in the interbed materials (DOE-ID, 2006; Winfield, 2003). Hydraulic conductivity values for the C-D interbed range over four orders of magnitude $\left(10^{-5}\right.$ to $10^{-1} \mathrm{~m} /$ day $)$, decrease with depth, and have a mean value of $5.76 \times 10^{-2} \mathrm{~m} /$ day. The average porosity for the C-D interbed is 0.496 (Winfield, 2002). The mean water level above the upper boundary of the C-D interbed for the duration of the second tracer test was $3.16 \mathrm{~m}$. A Darcy calculation using a pressure head of $3.16 \mathrm{~m}$, a flow velocity of $0.12 \mathrm{~m} / \mathrm{day}$, a vertical transport distance of $1.98 \mathrm{~m}$ and porosity of 0.496 yields a saturated hydraulic conductivity of $\sim 2 \times 10^{-2} \mathrm{~m} /$ day (see Appendix B for calculation). Clearly the interbeds are highly heterogeneous with respect to saturated hydraulic conductivity; however, the field-derived flow velocity yields an estimated value for $\mathrm{K}_{\mathrm{sat}}$ that is very close to the mean laboratory-derived $\mathrm{K}_{\mathrm{sat}}$ value (both on the order of $10^{-2} \mathrm{~m} /$ day). This agreement between laboratory- and field-derived transport parameters lends credence to the hypothesis that vertical flow occurs through the main bulk of the sedimentary material of the C-D interbed. 
A simple water-balance calculation was used to estimate the saturated vertical hydraulic conductivity of the C-D interbed on a larger scale than that interrogated by the preceding analysis. Assuming that water moves predominantly vertically from the surface and then spreads radially along the C-D interbed, the rate at which water percolates vertically through the interbed controls the extent to which the perched water spreads. During test 1, water reached well 197(B), located $\sim 268 \mathrm{~m}$ from the center of the south pond but failed to reach well 194(B), located $\sim 449 \mathrm{~m}$ from the center of the south pond (Fig. 2). These two wells provide bounding estimates of the radial distance that water traveled along the C-D interbed and thus of the area of the circles through which water percolated vertically. Darcy calculations using the two bounding areas $\left(2.3 \times 10^{5}\right.$ $\mathrm{m}^{2}$ and $6.3 \times 10^{5} \mathrm{~m}^{2}$ ) yielded estimates of vertical saturated hydraulic conductivity for the C-D interbed of $8 \times 10^{-3} \mathrm{~m} /$ day and $3 \times 10^{-3} \mathrm{~m} /$ day, respectively (see Appendix B for calculations). The fact that these values are so close to both the estimate based on the well 202(A)/lysimeter 204129(I) analysis ( 2 × $10^{-2} \mathrm{~m} /$ day $)$ and the mean laboratory value (5.76 $\times 10^{-2} \mathrm{~m} /$ day) suggests that the interbed: (1) is laterally continuous over an extensive area, (2) does not contain significant high-permeability vertical channels, and (3) is homogeneous enough that its large-scale effective vertical permeability is represented quite well by averaged point measurements.

Analysis of tracer breakthrough in well 212 can also be used to further our investigation into the nature of transport through the vadose zone. Well 212 is completed at a depth of $79 \mathrm{~m}$ bls and is located between the two ponds almost directly below the infiltration point (Fig. 2). The well penetrates a total of $8 \mathrm{~m}$ of sedimentary material and $\sim 1 \mathrm{~m}$ of clay-filled fractured basalt distributed in four separate interbeds. Cement grout 
and bentonite plugs from land surface to approximately $2 \mathrm{~m}$ above the screened interval prevents vertical flow down the annulus of the well. Transport through the ESRP vadose zone to the regional aquifer can be conceptualized in terms of two end members. The first of these is that water moves primarily through the fractured basalt, traveling laterally along the tops of the sedimentary interbeds until a gap is found. The second end member is that vertical transport rates are predominantly controlled by transport through the sedimentary material of the interbeds and associated clay-filled fractures in the basalt. Presumably the true transport paths lie between these two extremes. In order to assess the nature of flow paths through the interbeds, two forward simulations were carried out and compared with the test 2 data from well 212 (Fig. 8). In both simulations lateral flow

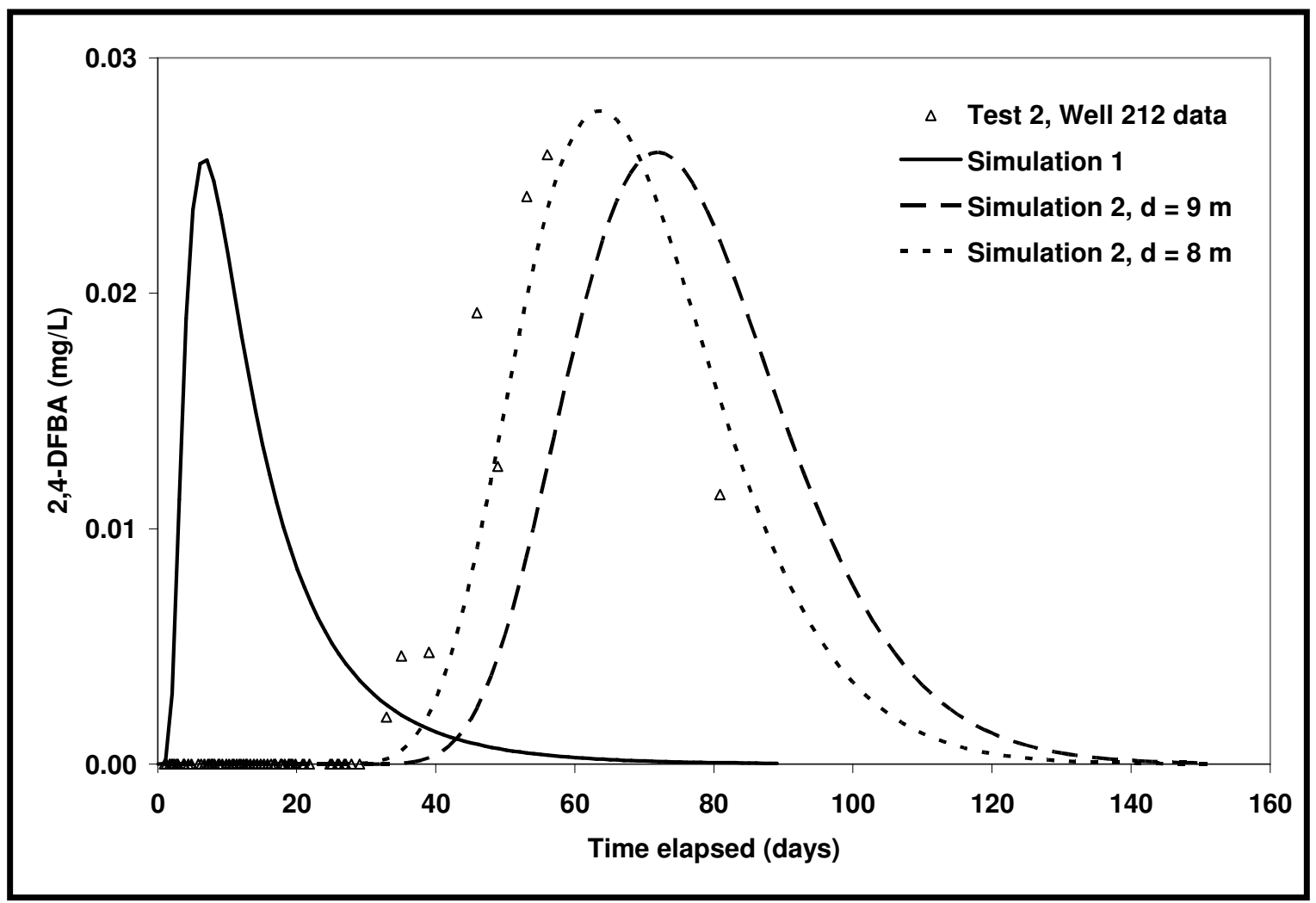

Figure 8: Results of CXTFIT simulations compared with test 2 well 212 breakthrough data (see text for conceptual model in each simulation) 
is not included as lateral flow velocities are rapid in comparison to vertical flow velocities (see next section for discussion of lateral flow along basalt/interbed contacts). In the first simulation flow and transport are assumed to be predominantly through the basalt (i.e. flow bypasses the sedimentary material and associated clay-filled fractures of the interbeds). In the second simulation, flow and transport are assumed to be through the sedimentary interbeds and associated basalt with clay-filled fractures with no bypassing. Since transport velocities through the basalt are roughly two orders of magnitude faster than those through the interbed (table 3), flow through the basalt is neglected in simulation 2 .

The forward simulations clearly show that transport parameters for the sedimentary material of the interbeds and the associated clay-filled fractured basalt best match the test 2 well 212 BTC (Fig. 8). The simulation in which the interbeds are neglected predicts initial arrival of tracer in well $212 \sim 25$ days too early. This simulation also predicts a very steep rising limb of the BTC whereas the data show a slower, shallower rise in tracer concentrations. The results of simulation 2 provide a much closer match to the well 212 data with an initial arrival time of $\sim 40$ days. This result indicates that most of the tracer that arrived at well 212 likely traveled through the interbeds. The simulated breakthrough is somewhat later than that observed in well 212; however the fit is considerably improved by decreasing the assumed effective interbed thickness to $8 \mathrm{~m}$ instead of $9 \mathrm{~m}$. Although the difference between an effective interbed thickness of $8 \mathrm{~m}$ and $9 \mathrm{~m}$ is small considering the uncertainties inherent in this analysis, the improved fit using the smaller number does allow the possibility that some flow may bypass the interbed material. Other possibilities that could account for this relatively small 
difference between predicted and measured interbed thicknesses without any bypassing include spatial variability of interbed thickness surrounding well 212; locally higher heads due to variable perched water thickness above the C-D interbed or other interbeds penetrated by well 212; and heterogeneity in hydraulic conductivity both within and between the C-D interbed and the deeper interbeds.

Comparison of field-derived hydraulic conductivity values with those generated in the laboratory, together with a simple model analysis of tracer breakthrough at a deep well, provide strong evidence that solutes move through both the sedimentary material and the associated clay-filled fractures in the basalt during vertical transport. A small degree of bypassing is allowed by the data but not required, given the uncertainties inherent in this analysis and the likely variable thicknesses and heterogeneous characteristics of the interbed materials. This finding has important implications for contaminant transport as retardation of reactive solutes is expected to be much higher in sedimentary material and clay-filled fractures than in the basalt alone (Magnuson and Sondrup, 2006).

\section{Lateral transport along the basalt/interbed contact}

When water infiltrating vertically through the variably saturated basalt reaches a sedimentary interbed it forms a perched layer. From this perched layer water is redistributed both vertically through and laterally along the interbed. Tracer recovery at well 200(B) and at well 197(B) (Fig. 2 and 3) may be used to provide insight into the lateral component of this flow. Well 200(B) is completed above the upper boundary of the C-D interbed slightly to the north of the north pond. Well 197(B) is similarly 
completed above the C-D interbed approximately $86 \mathrm{~m}$ due north of well 200(B). A Darcy calculation was carried out using a hydraulic gradient based on water levels in wells 200(B) and 197(B), tracer arrival times at the two wells, and an assumed porosity of 0.5 (a reasonable assumption for both C-D interbed (Winfield, 2002) and the basalt rubble zone (Smith, 2004)). If flow from well 200(B) to well 197(B) is assumed to be linear in nature this calculation yields an estimated mean $\mathrm{K}_{\mathrm{sat}}$ of $\sim 500 \mathrm{~m} /$ day; if a radial flow assumption is made the calculated value is $\sim 900 \mathrm{~m} /$ day. Nimmo (2004b) states that the saturated hydraulic conductivity of basalt rubble zones is likely similar to that of gravel and could easily exceed $800 \mathrm{~m} /$ day. In contrast the mean vertical saturated hydraulic conductivity of the C-D interbed as determined by Winfield (2003) is $5.76 \mathrm{x}$ $10^{-2} \mathrm{~m} /$ day and tracer breakthrough analysis presented above yields a comparable value

of $2 \times 10^{-2} \mathrm{~m} /$ day. Even allowing for the possibility that the sedimentary materials of the interbed have high horizontal to vertical anisotropy in hydraulic conductivity, this large contrast in $\mathrm{K}_{\mathrm{sat}}$ values strongly suggests that lateral flow occurred in the basalt rubble above the C-D interbed rather than within the sedimentary material itself.

\section{Perching behavior at different geologic contacts}

Perching behavior at the alluvium/basalt contact differs significantly from that which occurs at the basalt/interbed contact. Although a saturated layer did form at the alluvium/basalt contact, it was not persistent once the source of water from the surface was discontinued. In contrast, the perched layer that formed at the basalt/interbed contact remained stable even after the source was moved between ponds. The perched water at 
the alluvium/basalt contact did not extend far beyond the wetted footprint at the surface, whereas the perched layer that formed at the basalt/interbed contact extended well beyond the surface infiltration source, clearly indicating significant lateral flow (on the order of 100s of meters). This dissimilarity in perching behavior suggests that the perching mechanisms at the two contacts are different. We suggest that when unconsolidated material overlies fractured rock (as typified by the alluvium/basalt contact), the underlying rock functions as a capillary barrier and water moves into the basalt when the head above the contact exceeds the air-entry pressure of the transmissive fractures. In contrast, the thicker, more extensive perching at the basalt/interbed contact is likely due to the permeability contrast between the high-permeability basalt rubble zone and the underlying low-permeability interbed sediments.

\section{Comparison of flow velocities in test 1 and test 2}

Flood events in semiarid systems occur on a variety of temporal scales. For example, at INL, infiltration from the Big Lost River and associated spreading areas may continue for months or years whereas local snowmelt and rainfall may cause intense infiltration events that last from days to weeks. These two temporal scales are simulated by test 1 and test 2 respectively. Test 1 was conducted after water had been infiltrating for roughly nine months. In contrast, test 2 was conducted in an initially dry setting and the test duration was approximately two months. Flow velocities calculated for test 1 are consistently faster than those calculated for test 2 (Table 3). 
Two fundamental differences between test 1 and test 2 are the antecedent wetness and the location of the infiltration points. The fact that tests 1 and 2 were carried out in separate ponds allows the possibility that differences in flow velocities are due to flow through different pathways. However, in such a case it would also be expected that there would be a distribution of flow velocities and that each different infiltration location would produce some slower and some faster pathways. There is no a priori reason to expect that flow paths from one pond would give rise to consistently higher flow velocities than another. Rather, the consistent trend of faster flow velocities in test 1 suggests that system wetness is an important controlling factor in both the basalt and the alluvium. This correlation is presumably related to increased unsaturated hydraulic conductivity associated with increased moisture content. In addition, once the flow field approaches steady state flow velocities in the fractured basalt may be higher due to the presence of saturated or near saturated fractures that are able to act immediately as transmissive pathways. This interpretation suggests that during long-term infiltration events velocities in the alluvium may be as much as a factor of two to three higher than during initial infiltration into a dry system. Similarly, flow through the alluvium/basalt complex may be expected to be 50-100\% faster under wetter antecedent conditions. Thus, the relative difference in flow velocities calculated for test 1 and test 2 may be useful in evaluating contaminant transport under temporally different infiltration scenarios. 


\section{CONCLUSION}

The work outlined in this paper provides evidence that, when driven by high-flux infiltration from the surface, flow occurs in fractures even when matrix saturations are low. This fracture flow gives rise to vertical transport rates that are much higher than would be predicted based on the assumption that the flow occurs primarily in the matrix. Vertical flow velocities through the combined surficial alluvium and fractured basalt at the VZRP were determined to range between 5 and 20 m/day. Flow velocities were 50$100 \%$ faster under quasi-steady-state conditions with higher antecedent wetness than they were when infiltration occurred under initially dry and highly transient conditions. This increase in flow rates is presumed to be due to higher unsaturated hydraulic conductivities related to higher moisture contents. In addition, we propose that under steady-state conditions flow velocities increase because fractures are already behaving as active transmissive pathways, in contrast to the transient case in which the fractures must go through an initial wetting-up phase.

Perching and flow behavior at two types of geologic contacts were investigated during this study: the contact between the surficial alluvium and the underlying basalt and the contact between basalt and a sedimentary interbed. The dissimilarity in perching behavior suggests a fundamental difference in the perching mechanism at the two contacts. We propose that when unconsolidated sediment overlies fractured rock the underlying rock presents a capillary barrier with water moving vertically into the rock only when the head above the contact exceeds the air-entry pressure of the fractures. In contrast, when fractured rock overlies sedimentary material, perching appears to be due 
to the contrast in permeability between the high-permeability fractured rock and the relatively low-permeability interbed sediments. This is an important distinction inasmuch as the capillary barrier mechanism is head-dependent and may therefore give rise to pulsing or flushing of flow across the contact whereas the permeability-controlled mechanism is independent of head above the contact and is therefore a permanent feature of the subsurface environment.

Water perched above the C-D interbed flowed laterally and also percolated vertically through the sedimentary material of the interbed. Results of our tracer tests suggest that lateral flow along the basalt/interbed contact occurs in a high-permeability, high-porosity zone, perhaps of basalt rubble, that lies above the sedimentary interbed. The mean saturated hydraulic conductivity of this zone is estimated to be on the order of either 500 $\mathrm{m} /$ day or $900 \mathrm{~m} /$ day for lateral and radial flow assumptions, respectively. Vertical flow occurs through the sedimentary material of the interbeds with little or no apparent bypassing of the interbed through preferential pathways. The estimated mean vertical saturated hydraulic conductivity of C-D interbed sediments based on analysis of flow at a single point is $\sim 2 \times 10^{-2} \mathrm{~m} /$ day; a larger scale analysis yielded bounding values of $3 \times 10^{-3} \mathrm{~m} /$ day and $8 \times 10^{-3} \mathrm{~m} /$ day for infiltration through an interbed area of $\sim 10^{5} \mathrm{~m}^{2}$.

\section{ACKNOWLEDGMENTS}

This work was supported by the Environmental Management Science Program of the Office of Science, U.S. Department of Energy. We would like to thank Leah Street and her crew for great operational support in the field at INL. In addition, we would like to 
thank Dr. John Nimmo and two anonymous reviewers for very thorough reviews that greatly improved this paper 


\section{REFERENCES}

Ackerman, D. J. (1991), Transmissivity of perched aquifers at the Idaho National Engineering Laboratory, Idaho, Water-resources investigations report, 91-4114, USGS, Idaho Falls.

Adam, M. L., Comfort, S. D., Morley, M. C., and Snow, D. D. (2004), Remediating RDX-contaminated ground water with permanganate: Laboratory investigations for the Pantex perched aquifer, Journal of Environmental Quality, 33, 2165-2173.

Anderson, S. R., and Lewis, B. D. (1989), Stratigraphy of the unsaturated zone at the radioactive waste management complex, Idaho National Engineering Laboratory, Idaho, Water-Resources Investigations Report, 89-4065, USGS, Idaho Falls.

Baker, K. E., Hull, L. C., Bennett, J., Ansley, S. L., and Heath, G. (2004), Conceptual models of flow through a heterogeneous, layered vadose zone under a percolation pond, INEEL/EXT-04-01679, INEEL, Idaho Falls.

Barraclough, J. T., Robertson, J. B., and Janzer, V. J. (1976), Hydrology of the solid waste burial ground, as related to the potential migration of radionuclides, Idaho National Engineering Laboratory, Open-File Report, 76-471, USGS, Idaho Falls.

Bear, J. (1972), Dynamics of fluids in porous media, 764 pp., Elsevier, New York.

Becker, M. W., and Shapiro, A. M. (2003), Interpreting tracer breakthrough tailing from different forced-gradient tracer experiment configurations in fractured bedrock, Water Resources Research, 39, doi:10.1029/2001WR001190.

Bishop, C. W. (1991), Hydraulic properties of vesicular basalt, M.S. thesis, University of Arizona. 
Cecil, L. D., Orr, B. R., Norton, T., and Anderson, S. R. (1991), Formation of perched ground-water zones and concentrations of selected chemical constituents in water, Idaho National Engineering Laboratory, Idaho, 1986-1988, Water-Resources Investigations, 91-4166, DOE/ID-22100, USGS, Idaho Falls, ID.

DOE-ID (2006), Operable unit 3-14 tank farm soil and groundwater remedial investigation/baseline risk assessment, DOE/NE-ID-11227, Rev. 0, U.S. Department of Energy Idaho Operations Office.

Doughty, C. (2000), Numerical model of water flow in a fractured basalt vadose zone: Box Canyon site, Idaho, Water Resources Research, 36, 3521-3534.

Dunnivant, F. M., Newman, M. E., Bishop, C. W., Burgess, D., Giles, J. R., Higgs, B. D., Hubbell, J. M., Neher, E., Norrell, G. T., Pfiefer, M. C., Porro, I., Starr, R. C., and Wyllie, A. H. (1998), Water and radioactive tracer flow in a heterogeneous field-scale system, Ground Water, 36, 949-958.

Dunnivant, F. M., Newman, M. E., Magnuson, S. O., and McCarthy, J. (1995), Modeling of radioactive tracer data collected during the large-scale pumping and infiltration test: water velocity and dispersivity estimates, Eos Trans., 76, Suppl., 266.

Fabryka-Martin, J., Wightman, S. J., Murphy, W. J., Wickham, M. P., Caffee, M. W., Nimz, G. J., Southon, J. R., and Sharma, P. (1993), Distribution of chlorine-36 in the unsaturated zone at Yucca Mountain: an indicator of fast transport paths, paper presented at FOCUS '93, Site Characterization and Model Validation, American Nuclear Society, Las Vegas, NV.

Fabryka-Martin, J., Wightman, S. J., Robinson, B. A., and Vestal, E. W. (1994), Infiltration processes at Yucca Mountain inferred from chloride and chlorine-36 
distributions, Los Alamos National Laboratory Milestone Report, 4317, Los Alamos, NM.

Faybishenko, B., Doughty, C., Steiger, M., Long, J. C. S., Wood, T. R., Jacobsen, J. S., Lore, J., and Zawislanski, P. T. (2000), Conceptual model of the geometry and physics of water flow a fractured basalt vadose zone, Water Resources Research, 36, 3499-3520.

Finsterle, S., Fabryka-Martin, J. T., and Wang, J. S. Y. (2002), Migration of a water pulse through fractured porous media, Journal of Contaminant Hydrology, 54, 37-57.

Flint, A. L., Flint, L. E., Bodvarsson, G. S., Kwicklis, E., and Fabryka-Martin, J. (2001a), Evolution of the conceptual model of unsaturated zone hydrology at Yucca Mountain, Nevada, Journal of Hydrology, 247, 1-30.

Flint, A. L., Flint, L. E., Kwicklis, E. M., Bodvarsson, G. S., and Fabryka-Martin, J. M. (2001b), Hydrology of Yucca Mountain, Nevada, Reviews of Geophysics, 39, 447470.

Gauthier, J. H., Wilson, M. L., and Lauffer, F. C. (1992), Estimating the consequences of significant fracture flow at Yucca Mountain, paper presented at Third Annual International High-Level Radioactive Waste Management Conference, American Nuclear Society, LaGrange Park, IL.

Haggerty, R., McKenna, S. A., and Meigs, L. C. (2000), On the late-time behavior of tracer test breakthrough curves, Water Resources Research, 36, 3467-3479.

Hull, L. C., and Bishop, C. W. (2003), Fate of brine applied to unpaved roads at a radioactive waste subsurface disposal area, Vadose Zone Journal, 3, 190-202. 
Illman, W. A. and Hughson, D.L. (2005), Stochastic simulations of steady state unsaturated flow in a three-layer, heterogeneous, dual continuum model of fractured rock, Journal of Hydrology, 307, 17-37.

Liu, H.-H., C. Doughty, and G. S. Bodvarsson, 1998. An active fracture model for unsaturated flow and transport in fractured rocks, Water Resources Research, 34, 2633-2646.

Knutson, C. F., McCormick, K. A., Crocker, J. C., Glenn, M. A., and Fishel, M. L. (1992), 3D RWMC vadose zone modeling, EGG-ERD-10246, EG\&G, Idaho Falls, ID.

Magnuson, S. O. (1995), Inverse modeling for field-scale hydrologic and transport parameters of fractured basalt, INEL-95/0637, Idaho National Engineering Laboratory.

Magnuson, S. O. (2004), Regulatory modeling for the Idaho National Engineering and Environmental Laboratory's Subsurface Disposal Area and conceptual model uncertainty treatment, Vadose Zone Journal, 3, 59-74.

Magnuson, S. O., and Sondrup, A. J. (2006), Subsurface flow and transport model development for the operable unit 7-13/14 remedial investigation and feasibility study, ICP/EXT-05-01016, Idaho Cleanup Project, Idaho Falls, ID.

Maloszewski, P., and Zuber, A. (1993), Tracer experiments in fractured rocks: Matrix diffusion and the validity of models, Water Resources Research, 29, 2723-2735.

Mattson, E. D., Magnuson, S. O., and Ansley, S. L. (2004), Interpreting INEEL vadose zone water movement on the basis of large-scale field tests and long-term vadose zone monitoring results, Vadose Zone Journal, 3, 35-46. 
McLaren, R.G., Forsyth, P.A., Sudicky, E.A., VanderKwaak, J.E., Schwartz, F.W., and Kessler, J.H. (2000), Flow and transport in fractured tuff at Yucca Mountain: numerical experiments on fast preferential flow mechanisms, Journal of Contaminant Hydrology, 43, 211-238.

Mohanty, B. P., Bowman, R. S., Hendrickx, J. M. H., Simunek, J., and van Genuchten, M. T. (1998), Preferential transport of nitrate to a tile drain in an intermittent-floodirrigated field: Model development and experimental evaluation, Vadose Zone Journal, 34, 1061-1076.

Montazer, P., and Wilson, W. E. (1984), Conceptual hydrologic model of flow in the unsaturated zone, Yucca Mountain, Nevada, U.S. Geological Survey Water Resources Investigation Report, 84-4345, 29 pp.

Neretnieks, I. (1993), Solute transport in fractured rock--applications to radionuclide waste repositories, in Flow and contaminant transport in fractured rock, J. Bear, C.-F. Tsang, and G. de Marsily, pp. 39-127, Academic Press, Inc., San Diego.

Newman, M. E., and Dunnivant, F. M. (1995), Results from the large-scale aquifer pumping and infiltration tests: Transport of tracers through fractured media, INEL95/146 ER-WAG7-77, Idaho National Engineering and Environmental Laboratory.

Nimmo, J. R., Perkins, K. S., Rose, P. E., Rousseau, J. P., Orr, B. R., Twining, B. V., and Anderson, S. R. (2002), Kilometer-scale rapid transport of naphthalene sulfonate tracer in the unsaturated zone at the Idaho National Engineering and Environmental Laboratory, Vadose Zone Journal, 1, 89-101.

Nimmo, J. R., Perkins, K. S., and Winfield, K. A. (2004a), Unsaturated-zone case study at the Idaho National Engineering and Environmental Laboratory: Can Darcian 
hydraulic properties predict contaminant migration?, paper presented at Geological Society of America, Denver, CO.

Nimmo, J. R., Rousseau, J. P., Perkins, K. S., Stollenwerk, K. G., Glynn, P. D., Bartholomay, R. C., and Knobel, L. L. (2004b), Hydraulic and geochemical framework of the Idaho National Engineering and Environmental Laboratory vadose zone, Vadose Zone Journal, 3, 6-34.

Parker, J. C., and van Genuchten, M. T. (1984), Determining transport parameters from laboratory and field tracer experiments, paper presented at Bull. Va. Agric. Exp. St., Blacksburg.

Peters, R. R., and Klavetter, E. A. (1988), A continuum model for water movement in an unsaturated fractured rock mass, Water Resources Research, 24, 416-430.

Pruess, K. (1999), A mechanistic model for water seepage through thick unsaturated zones in fractured rocks of low matrix permeability, Water Resources Research, 35, 1039-1051.

Rightmire, C. T., and Lewis, B. D. (1987), Hydrogeology and geochemistry of the unsaturated zone, Radioactive Waste Management Complex, Idaho National Engineering Laboratory, Idaho, Water-Resources Investigations Report, 87-4198, USGS.

Robinson, B., and Tester, J. (1986), Characterization of flow maldistribution using inletoutlet tracer techniques: An application of internal residence time distributions, Chemical Engineering Science, 41, 469-484.

Robinson, B. A., Broxton, D. E., and Vaniman, D. T. (2005), Observations and modeling of deep perched water beneath the Pajarito Plateau, Vadose Zone Journal, 4, 637-652. 
Schaefer, C. J., and Kattenhorn, S. A. (2004), Characterization and evolution of fractures in low-volume pahoehoe lava flows, eastern Snake River Plain, Idaho, Geological Society of America Bulletin, 116(3): 322-336.

Smith, R. P. (2004), Geologic setting of the Snake River Plain Aquifer and Vadose Zone, Vadose Zone Journal, 3, 47-58.

Toride, N., Leij, F. J., and van Genuchten, M. T. (1999), The CXTFIT code for estimating transport parameters from laboratory or field tracer experiments, Research report no. 137, U.S. Salinity Laboratory, USDA, Riverside, CA.

Tsang, Y. W. (1995), Study of alternative tracer tests in characterizing transport in fractured rocks, Geophysical Research Letters, 22, 1421-1424.

Wang, J. S. Y., and Narasimhan, T. N. (1985), Hydrologic mechanisms governing fluid flow in a partially saturated, fractured, porous medium, Water Resources Research, 21, 1861-1874.

Wang, J. S. Y., and Narasimhan, T. N. (1993), Unsaturated flow in fractured porous media, in Flow and contaminant transport in fractured rock, J. Bear, C.-F. Tsang, and G. de Marsily, pp. 325-394, Academic Press, Inc., San Diego.

Winfield, K. A. (2002), Measurement of unsaturated hydraulic conductivity functions, saturated hydraulic conductivity, particle-size distribution bulk density, porosity, and specific surface area for Vadose Zone Research Park samples, Idaho National Engineering and Environmental Laboratory (INEEL), Summary Report, USGS, Menlo Park, CA.

Winfield, K. A. (2003), Spatial variability of sedimentary interbed properties near the Idaho Nuclear Technology and Engineering Center at the Idaho National Engineering 
and Environmental Laboratory, Idaho, Water-Resources Investigations Report, 034142, USGS, Idaho Falls, ID.

Wood, T. R., and Norrell, G. T. (1996), Integrated large-scale aquifer pumping and infiltration tests: Groundwater pathways OU 7-06 Summary report, INEL-96/0256, Idaho National Engineering and Environmental Laboratory, Idaho Falls, ID.

Yang, I. C., Rattray, G. W., and Yu, P. (1996), Interpretations of chemical and isotopic data from boreholes in the unsaturated-zone at Yucca Mountain, Nevada, WaterResources Investigations Report, 96-4058, USGS. 


\section{CONCLUDING REMARKS}

The work presented in this thesis is part of a larger study conducted at the Vadose Zone Research Park at Idaho National Laboratory. The goals of the broader project included investigation of the potential role of matrix diffusion in contaminant transport through variably-saturated fractured media. As is discussed in the preceding manuscript, flow in the fractured basalt of the eastern Snake River Plain is known to be highly channeled and preferential in nature. Diffusive mass transfer between a variety of flowing and stagnant fluid domains has been postulated by other workers as part of the conceptual model of flow and transport in the ESRP basalt. In order to assess the role of matrix diffusion in this system, the second tracer test described in this thesis included the injection of two conservative solutes, bromide and 2,4-difluorobenzoate. Analysis of the resulting breakthrough curves allowed the identification and quantification of matrix diffusion as an important transport process in the variably-saturated fractured basalts of the ESRP. A manuscript describing the field experiment and associated modeling and analysis is currently in process.

It is clear from this study that, when driven by high-flux infiltration from the surface, flow occurs in fractures even when matrix pore pressures are negative (i.e., the matrix is unsaturated). This fracture flow gives rise to vertical transport rates that are much higher than would be predicted based on the assumption that the flow occurs primarily in the matrix. Further studies should be carried out with the goal of quantifying the relationship between matrix saturation and fracture flow. 
Flow velocities were 50-100\% faster under quasi-steady-state conditions with higher antecedent wetness than they were when infiltration occurred under initially dry and highly transient conditions. This increase in flow rates is presumed to be due to higher unsaturated hydraulic conductivities related to higher moisture contents. In addition, we propose that under steady-state conditions flow velocities increase because fractures are already behaving as active transmissive pathways, in contrast to the transient case in which the fractures must go through an initial wetting-up phase.

Perching and flow behavior at two types of geologic contacts were investigated during this study: the contact between the surficial alluvium and the underlying basalt and the contact between basalt and a sedimentary interbed. The dissimilarity in perching behavior suggests a fundamental difference in the perching mechanism at the two contacts. It appears that when unconsolidated sediment overlies fractured rock the underlying rock presents a capillary barrier with water moving vertically into the rock only when the head above the contact exceeds the air-entry pressure of the fractures. In contrast, when fractured rock overlies sedimentary material, perching appears to be due to the contrast in permeability between the high-permeability fractured rock and the relatively low-permeability interbed sediments. This is an important distinction inasmuch as the capillary barrier mechanism is head-dependent and may therefore give rise to pulsing or flushing of flow across the contact whereas the permeability-controlled mechanism is independent of head above the contact and is therefore a permanent feature of the subsurface environment. 
The experiments presented in this thesis provide interesting, first-order insights into the behavior of a variably-saturated geologic system consisting of interlayered granular and fractured crystalline media. Suggested future work includes:

1) Pumping tests carried out in the perched zones with the aim of providing transmissivity and storage parameters for perched aquifers in the basalt and in the surficial alluvium.

2) Focused tracer tests conducted by injecting tracer into one well and pumping another rather than introducing tracer at the surface. This would allow specific domains to be interrogated and transport behavior to be better defined in for each of the three main geologic domains. Transport parameters thus generated could be used to populate numerical models free of the ambiguity associated with information gathered from integrated domains.

3) Introduction of a mildly sorbing tracer such as lithium ion in order to gain further insight into the sorptive capacity of the two sedimentary domains, as well as to investigate the degree to which channeling occurs within flowing fracture planes.

4) Integration of geophysical, geochemical and hydrological data with tracer test data in order to provide a more thorough understanding of the environment through which tracers are moving and quantify the effects of transient infiltration on transport 


\section{APPENDIX A: HIGH-PERFORMANCE LIQUID CHROMATOGRAPHY DATA}

Fluorobenzoic acid (FBA) analyses were conducted at Los Alamos National

Laboratory using a Dionex high-performance liquid chromatography (HPLC) system. The system components included an IP-20 isocratic pump and an AD-25 absorbance detector. The mobile phase used for analysis of test one samples was $50 \%$ methanol, $34 \% 18 \mathrm{M} \Omega$ deionized water and $16 \% \mathrm{~K}_{2} \mathrm{HPO}_{4}$ buffer; for test two samples the mobile phase was $40 \%$ methanol, $44 \% 18 \mathrm{M} \Omega$ deionized water and $16 \% \mathrm{~K}_{2} \mathrm{HPO}_{4}$ buffer. For both tests the mobile phase was adjusted to $\mathrm{pH}<3$ with $\mathrm{H}_{3} \mathrm{PO}_{4}$ to ensure that the FBAs remained protonated during analysis. Absorbance detection wavelength was $230 \mathrm{~nm}$. Pumping rate was $0.3 \mathrm{~mL} / \mathrm{min}$.

The tables below contain the FBA concentrations from samples collected during the two tracer tests. Test one sample identifiers consist of the number 3, the well or lysimeter identifier, and a number indicating the order in which the sample was collected. For example the identifier for the first test one sample collected from well 197 is 3-197-001. Sample identifiers in the tables are not consecutive as not all samples were analyzed for FBAs (some were for cations, isotopes etc.). Test two sample identifiers begin with Tst2 and include the well or lysimeter identifier, and a number indicating the order in which the sample was collected. For example the identifier for the first test two sample collected from well 197 is Tst2-197-001. Some late-time test one data have test two sample identifiers because the test one tracer (2,4,5-TFBA) was still breaking through during the test two sampling period. The tables include the date and time at which the sample was collected, the time elapsed since tracer injection, and the FBA concentration for that sample in milligrams per liter $(\mathrm{mg} / \mathrm{L})$. 
Table A-1: HPLC data from test 1, well 197

\begin{tabular}{|c|c|c|c|c|}
\hline Sample Name & Date & Time & $\begin{array}{l}\text { Time elapsed } \\
\text { (days) }\end{array}$ & $\begin{array}{c}2,4,5-\mathrm{TFBA} \\
(\mathrm{mg} / \mathrm{L})\end{array}$ \\
\hline 3-197-002 & $6 / 10 / 2003$ & $18: 50$ & -0.69 & $<0.008$ \\
\hline 3-197-004 & $6 / 11 / 2003$ & $16: 28$ & 0.21 & $<0.008$ \\
\hline 3-197-006 & $6 / 11 / 2003$ & $19: 18$ & 0.33 & $<0.008$ \\
\hline 3-197-008 & $6 / 11 / 2003$ & 23:04 & 0.49 & $<0.008$ \\
\hline 3-197-009 & $6 / 12 / 2003$ & 5:04 & 0.74 & $<0.008$ \\
\hline 3-197-011 & $6 / 12 / 2003$ & $10: 24$ & 0.96 & $<0.008$ \\
\hline 3-197-013 & $6 / 12 / 2003$ & $15: 16$ & 1.16 & $<0.008$ \\
\hline 3-197-015 & $6 / 12 / 2003$ & $19: 25$ & 1.34 & $<0.008$ \\
\hline 3-197-017 & $6 / 12 / 2003$ & $22: 55$ & 1.48 & $<0.008$ \\
\hline 3-197-019 & $6 / 13 / 2003$ & $5: 40$ & 1.76 & $<0.008$ \\
\hline 3-197-021 & $6 / 13 / 2003$ & $9: 55$ & 1.94 & $<0.008$ \\
\hline 3-197-023 & $6 / 13 / 2003$ & $15: 00$ & 2.15 & $<0.008$ \\
\hline 3-197-025 & $6 / 13 / 2003$ & 19:00 & 2.32 & $<0.008$ \\
\hline 3-197-027 & $6 / 13 / 2003$ & $22: 30$ & 2.47 & $<0.008$ \\
\hline 3-197-029 & $6 / 14 / 2003$ & $5: 48$ & 2.77 & $<0.008$ \\
\hline 3-197-031 & $6 / 14 / 2003$ & $10: 22$ & 2.96 & $<0.008$ \\
\hline 3-197-033 & $6 / 14 / 2003$ & $15: 00$ & 3.15 & $<0.008$ \\
\hline 3-197-035 & $6 / 14 / 2003$ & 19:12 & 3.33 & $<0.008$ \\
\hline 3-197-037 & $6 / 14 / 2003$ & $22: 50$ & 3.48 & $<0.008$ \\
\hline 3-197-039 & $6 / 15 / 2003$ & $5: 49$ & 3.77 & $<0.008$ \\
\hline 3-197-041 & $6 / 15 / 2003$ & $9: 54$ & 3.94 & $<0.008$ \\
\hline 3-197-044 & $6 / 15 / 2003$ & $15: 05$ & 4.16 & $<0.008$ \\
\hline 3-197-046 & $6 / 15 / 2003$ & $19: 53$ & 4.36 & $<0.008$ \\
\hline 3-197-048 & $6 / 15 / 2003$ & $22: 33$ & 4.47 & $<0.008$ \\
\hline 3-197-049 & $6 / 16 / 2003$ & $7: 40$ & 4.85 & $<0.008$ \\
\hline 3-197-051 & $6 / 16 / 2003$ & $10: 57$ & 4.98 & $<0.008$ \\
\hline 3-197-057 & $6 / 17 / 2003$ & $10: 56$ & 5.98 & $<0.008$ \\
\hline 3-197-059 & $6 / 17 / 2003$ & $13: 26$ & 6.09 & $<0.008$ \\
\hline 3-197-061 & $6 / 17 / 2003$ & $17: 52$ & 6.27 & $<0.008$ \\
\hline 3-197-063 & $6 / 17 / 2003$ & 21:06 & 6.41 & $<0.008$ \\
\hline 3-197-065 & $6 / 18 / 2003$ & 5:08 & 6.74 & $<0.008$ \\
\hline 3-197-067 & $6 / 18 / 2003$ & $9: 57$ & 6.94 & $<0.008$ \\
\hline 3-197-070 & $6 / 18 / 2003$ & $15: 43$ & 7.18 & $<0.008$ \\
\hline 3-197-071 & $6 / 18 / 2003$ & $21: 55$ & 7.44 & $<0.008$ \\
\hline 3-197-073 & $6 / 19 / 2003$ & $6: 15$ & 7.79 & $<0.008$ \\
\hline 3-197-075 & $6 / 19 / 2003$ & $11: 13$ & 8.00 & $<0.008$ \\
\hline 3-197-077 & $6 / 19 / 2003$ & $17: 23$ & 8.25 & $<0.008$ \\
\hline 3-197-079 & $6 / 19 / 2003$ & 22:09 & 8.45 & $<0.008$ \\
\hline 3-197-081 & $6 / 20 / 2003$ & $6: 24$ & 8.79 & $<0.008$ \\
\hline 3-197-083 & $6 / 20 / 2003$ & $11: 10$ & 8.99 & $<0.008$ \\
\hline 3-197-085 & $6 / 20 / 2003$ & $17: 13$ & 9.25 & 0.003 \\
\hline 3-197-087 & $6 / 20 / 2003$ & $21: 33$ & 9.43 & $<0.008$ \\
\hline 3-197-121 & $6 / 21 / 2003$ & $6: 23$ & 9.79 & 0.002 \\
\hline
\end{tabular}


Table A-1: Continued

\begin{tabular}{|c|c|c|c|c|}
\hline Sample Name & Date & Time & $\begin{array}{c}\text { Time elapsed } \\
\text { (days) }\end{array}$ & $\begin{array}{c}2,4,5-T F B A \\
(\mathrm{mg} / \mathrm{L})\end{array}$ \\
\hline 3-197-123 & $6 / 21 / 2003$ & $10: 53$ & 9.98 & 0.002 \\
\hline 3-197-125 & $6 / 21 / 2003$ & $17: 11$ & 10.24 & 0.006 \\
\hline 3-197-127 & $6 / 21 / 2003$ & $21: 09$ & 10.41 & 0.004 \\
\hline 3-197-129 & $6 / 22 / 2003$ & $6: 51$ & 10.81 & 0.005 \\
\hline 3-197-131 & $6 / 22 / 2003$ & $10: 46$ & 10.98 & 0.006 \\
\hline 3-197-133 & $6 / 22 / 2003$ & $17: 08$ & 11.24 & 0.010 \\
\hline 3-197-135 & $6 / 22 / 2003$ & $21: 00$ & 11.40 & 0.007 \\
\hline 3-197-139 & $6 / 23 / 2003$ & $6: 59$ & 11.82 & 0.010 \\
\hline 3-197-141 & $6 / 23 / 2003$ & 11:09 & 11.99 & 0.014 \\
\hline 3-197-143 & $6 / 23 / 2003$ & $17: 49$ & 12.27 & 0.013 \\
\hline 3-197-145 & $6 / 23 / 2003$ & $21: 01$ & 12.40 & 0.013 \\
\hline 3-197-147 & $6 / 24 / 2003$ & $6: 57$ & 12.82 & 0.015 \\
\hline 3-197-149 & $6 / 24 / 2003$ & $16: 05$ & 13.20 & 0.021 \\
\hline 3-197-151 & $6 / 25 / 2003$ & 7:22 & 13.83 & 0.023 \\
\hline 3-197-153 & $6 / 25 / 2003$ & $16: 39$ & 14.22 & 0.027 \\
\hline 3-197-155 & $6 / 26 / 2003$ & $7: 00$ & 14.82 & 0.025 \\
\hline 3-197-157 & $6 / 26 / 2003$ & $15: 43$ & 15.18 & 0.033 \\
\hline 3-197-159 & $6 / 30 / 2003$ & $15: 25$ & 19.17 & 0.058 \\
\hline Tst2-197-001 & $8 / 5 / 2003$ & $7: 55$ & 54.86 & 0.037 \\
\hline Tst2-197-005 & $8 / 5 / 2003$ & $9: 25$ & 54.92 & 0.031 \\
\hline Tst2-197-009 & $8 / 5 / 2003$ & $21: 12$ & 55.41 & 0.034 \\
\hline Tst2-197-013 & $8 / 6 / 2003$ & $8: 52$ & 55.90 & 0.025 \\
\hline Tst2-197-021 & $8 / 6 / 2003$ & $12: 16$ & 56.04 & 0.034 \\
\hline Tst2-197-025 & $8 / 6 / 2003$ & $19: 11$ & 56.33 & 0.034 \\
\hline Tst2-197-031 & $8 / 7 / 2003$ & $5: 54$ & 56.77 & 0.033 \\
\hline Tst2-197-037 & $8 / 7 / 2003$ & $18: 09$ & 57.28 & 0.027 \\
\hline Tst2-197-049 & $8 / 8 / 2003$ & $8: 50$ & 57.90 & 0.027 \\
\hline Tst2-197-053 & $8 / 8 / 2003$ & $10: 34$ & 57.97 & 0.031 \\
\hline Tst2-197-057 & 8/8/2003 & $17: 26$ & 58.25 & 0.033 \\
\hline Tst2-197-059 & $8 / 8 / 2003$ & $19: 48$ & 58.35 & 0.031 \\
\hline Tst2-197-061 & $8 / 8 / 2003$ & $22: 28$ & 58.46 & 0.040 \\
\hline Tst2-197-064 & $8 / 9 / 2003$ & $6: 47$ & 58.81 & 0.037 \\
\hline Tst2-197-067 & $8 / 9 / 2003$ & $9: 37$ & 58.93 & 0.031 \\
\hline Tst2-197-071 & $8 / 9 / 2003$ & $12: 08$ & 59.03 & 0.028 \\
\hline Tst2-197-073 & 8/9/2003 & $18: 00$ & 59.28 & 0.041 \\
\hline Tst2-197-077 & $8 / 9 / 2003$ & $20: 14$ & 59.37 & 0.030 \\
\hline Tst2-197-089 & $8 / 10 / 2003$ & $11: 38$ & 60.01 & 0.025 \\
\hline Tst2-197-091 & $8 / 10 / 2003$ & $18: 50$ & 60.31 & 0.028 \\
\hline Tst2-197-095 & $8 / 10 / 2003$ & $22: 50$ & 60.48 & 0.029 \\
\hline Tst2-197-097 & $8 / 11 / 2003$ & $9: 40$ & 60.93 & 0.028 \\
\hline Tst2-197-103 & $8 / 11 / 2003$ & $14: 30$ & 61.13 & 0.028 \\
\hline Tst2-197-111 & $8 / 11 / 2003$ & $20: 42$ & 61.39 & 0.032 \\
\hline Tst2-197-119 & $8 / 12 / 2003$ & $9: 25$ & 61.92 & 0.029 \\
\hline
\end{tabular}


Table A-1: Continued

\begin{tabular}{|c|c|c|c|c|}
\hline Sample Name & Date & Time & $\begin{array}{c}\text { Time elapsed } \\
\text { (days) }\end{array}$ & $\begin{array}{c}\text { 2,4,5-TFBA } \\
(\mathrm{mg} / \mathrm{L})\end{array}$ \\
\hline Tst2-197-123 & $8 / 12 / 2003$ & $15: 00$ & 62.15 & 0.031 \\
\hline Tst2-197-127 & $8 / 12 / 2003$ & $18: 38$ & 62.30 & 0.031 \\
\hline Tst2-197-129 & $8 / 12 / 2003$ & $21: 04$ & 62.41 & 0.029 \\
\hline Tst2-197-133 & $8 / 12 / 2003$ & $22: 44$ & 62.48 & 0.029 \\
\hline Tst2-197-135 & $8 / 13 / 2003$ & $5: 42$ & 62.77 & 0.03 \\
\hline Tst2-197-137 & $8 / 13 / 2003$ & $8: 41$ & 62.89 & 0.031 \\
\hline Tst2-197-141 & $8 / 13 / 2003$ & $10: 36$ & 62.97 & 0.025 \\
\hline Tst2-197-147 & $8 / 13 / 2003$ & $20: 50$ & 63.40 & 0.026 \\
\hline Tst2-197-151 & $8 / 13 / 2003$ & $22: 41$ & 63.47 & 0.027 \\
\hline Tst2-197-153 & $8 / 14 / 2003$ & $5: 50$ & 63.77 & 0.028 \\
\hline Tst2-197-155 & $8 / 14 / 2003$ & $8: 49$ & 63.90 & 0.029 \\
\hline Tst2-197-159 & $8 / 14 / 2003$ & $10: 42$ & 63.97 & 0.026 \\
\hline Tst2-197-161 & $8 / 14 / 2003$ & $17: 49$ & 64.27 & 0.025 \\
\hline Tst2-197-165 & $8 / 14 / 2003$ & $20: 13$ & 64.37 & 0.025 \\
\hline Tst2-197-167 & $8 / 14 / 2003$ & 22:31 & 64.47 & $<0.024$ \\
\hline Tst2-197-171 & $8 / 15 / 2003$ & $6: 03$ & 64.78 & $<0.024$ \\
\hline Tst2-197-177 & $8 / 15 / 2003$ & $12: 55$ & 65.07 & $<0.024$ \\
\hline Tst2-197-179 & $8 / 15 / 2003$ & $17: 42$ & 65.27 & $<0.024$ \\
\hline Tst2-197-183 & $8 / 15 / 2003$ & $20: 19$ & 65.37 & $<0.024$ \\
\hline Tst2-197-187 & $8 / 15 / 2003$ & 22:28 & 65.46 & $<0.024$ \\
\hline Tst2-197-189 & $8 / 16 / 2003$ & $6: 45$ & 65.81 & $<0.024$ \\
\hline Tst2-197-191 & $8 / 16 / 2003$ & 9:08 & 65.91 & $<0.024$ \\
\hline Tst2-197-195 & $8 / 15 / 2003$ & $10: 54$ & 64.98 & $<0.024$ \\
\hline Tst2-197-201 & $8 / 16 / 2003$ & 21:00 & 66.40 & $<0.024$ \\
\hline Tst2-197-205 & $8 / 16 / 2003$ & $22: 32$ & 66.47 & $<0.024$ \\
\hline Tst2-197-207 & $8 / 17 / 2003$ & $6: 40$ & 66.81 & $<0.024$ \\
\hline Tst2-197-209 & $8 / 17 / 2003$ & $8: 32$ & 66.88 & $<0.024$ \\
\hline Tst2-197-213 & $8 / 17 / 2003$ & $11: 12$ & 66.99 & $<0.024$ \\
\hline Tst2-197-215 & $8 / 17 / 2003$ & $17: 35$ & 67.26 & $<0.024$ \\
\hline Tst2-197-219 & $8 / 17 / 2003$ & $20: 14$ & 67.37 & $<0.024$ \\
\hline Tst2-197-223 & $8 / 17 / 2003$ & $22: 44$ & 67.48 & $<0.024$ \\
\hline Tst2-197-227 & $8 / 18 / 2003$ & $9: 43$ & 67.93 & $<0.024$ \\
\hline Tst2-197-231 & $8 / 18 / 2003$ & $12: 47$ & 68.06 & $<0.024$ \\
\hline Tst2-197-233 & $8 / 18 / 2003$ & $19: 36$ & 68.34 & $<0.024$ \\
\hline Tst2-197-237 & $8 / 18 / 2003$ & $22: 42$ & 68.47 & $<0.024$ \\
\hline Tst2-197-239 & $8 / 19 / 2003$ & $8: 18$ & 68.87 & $<0.024$ \\
\hline Tst2-197-245 & $8 / 19 / 2003$ & $14: 44$ & 69.14 & $<0.024$ \\
\hline Tst2-197-249 & $8 / 19 / 2003$ & $17: 29$ & 69.26 & $<0.024$ \\
\hline Tst2-197-251 & $8 / 19 / 2003$ & $20: 11$ & 69.37 & $<0.024$ \\
\hline Tst2-197-255 & $8 / 20 / 2003$ & $9: 42$ & 69.93 & $<0.024$ \\
\hline Tst2-197-261 & $8 / 20 / 2003$ & $17: 32$ & 70.26 & $<0.024$ \\
\hline Tst2-197-263 & $8 / 20 / 2003$ & $20: 15$ & 70.37 & $<0.024$ \\
\hline Tst2-197-267 & $8 / 21 / 2003$ & 9:06 & 70.91 & $<0.024$ \\
\hline
\end{tabular}


Table A-1: Continued

\begin{tabular}{|c|c|c|c|c|}
\hline Tst2-197-269 & $8 / 21 / 2003$ & $14: 47$ & 71.14 & $<0.024$ \\
\hline Tst2-197-279 & $8 / 25 / 2003$ & $8: 34$ & 74.88 & $<0.024$ \\
\hline Tst2-197-281 & $8 / 25 / 2003$ & $15: 30$ & 75.17 & $<0.024$ \\
\hline Tst2-197-285 & $8 / 26 / 2003$ & $9: 30$ & 75.92 & $<0.024$ \\
\hline Tst2-197-287 & $8 / 26 / 2003$ & $15: 34$ & 76.18 & $<0.024$ \\
\hline Tst2-197-291 & $8 / 27 / 2003$ & $8: 51$ & 76.90 & $<0.024$ \\
\hline Tst2-197-293 & $8 / 27 / 2003$ & $14: 25$ & 77.13 & $<0.024$ \\
\hline Tst2-197-297 & $8 / 28 / 2003$ & $10: 02$ & 77.95 & $<0.024$ \\
\hline Tst2-197-299 & $8 / 28 / 2003$ & $15: 25$ & 78.17 & $<0.024$ \\
\hline Tst2-197-303 & $8 / 29 / 2003$ & $14: 55$ & 79.15 & $<0.024$ \\
\hline Tst2-197-309 & $9 / 3 / 2003$ & $12: 20$ & 84.04 & $<0.024$ \\
\hline Tst2-197-311 & $9 / 4 / 2003$ & $13: 55$ & 85.11 & $<0.024$ \\
\hline Tst2-197-315 & $9 / 8 / 2003$ & $13: 34$ & 89.09 & $<0.024$ \\
\hline Tst2-197-317 & $9 / 9 / 2003$ & $11: 12$ & 89.99 & $<0.024$ \\
\hline Tst2-197-321 & $9 / 10 / 2003$ & $11: 10$ & 90.99 & $<0.024$ \\
\hline Tst2-197-323 & $9 / 11 / 2003$ & $11: 15$ & 92.00 & $<0.024$ \\
\hline Tst2-197-327 & $9 / 15 / 2003$ & $10: 35$ & 95.97 & $<0.024$ \\
\hline Tst2-197-329 & $9 / 16 / 2003$ & $8: 23$ & 96.88 & $<0.024$ \\
\hline Tst2-197-333 & $9 / 18 / 2003$ & $10: 10$ & 98.95 & $<0.024$ \\
\hline Tst2-197-335 & $9 / 22 / 2003$ & $15: 10$ & 103.16 & $<0.024$ \\
\hline Tst2-197-339 & $9 / 25 / 2003$ & $14: 55$ & 106.15 & $<0.024$ \\
\hline
\end{tabular}

Table A-2: HPLC data from test 1, well 200

\begin{tabular}{|c|c|c|c|c|}
\hline Sample Name & Date & Time & $\begin{array}{l}\text { Time elapsed } \\
\text { (days) }\end{array}$ & $\begin{array}{c}2,4,5-\mathrm{TFBA} \\
(\mathrm{mg} / \mathrm{L})\end{array}$ \\
\hline $3-200-001$ & $6 / 10 / 2003$ & $17: 57$ & -0.72 & $<0.008$ \\
\hline $3-200-004$ & $6 / 11 / 2003$ & $16: 40$ & 0.22 & $<0.008$ \\
\hline $3-200-006$ & $6 / 11 / 2003$ & $19: 30$ & 0.34 & $<0.008$ \\
\hline $3-200-008$ & $6 / 11 / 2003$ & $23: 13$ & 0.50 & $<0.008$ \\
\hline 3-200-009 & $6 / 12 / 2003$ & $8: 36$ & 0.89 & $<0.008$ \\
\hline 3-200-011 & $6 / 12 / 2003$ & $13: 12$ & 1.08 & $<0.008$ \\
\hline $3-200-013$ & $6 / 12 / 2003$ & $19: 37$ & 1.35 & $<0.008$ \\
\hline $3-200-015$ & $6 / 12 / 2003$ & $23: 07$ & 1.49 & $<0.008$ \\
\hline $3-200-017$ & $6 / 13 / 2003$ & $5: 54$ & 1.77 & $<0.008$ \\
\hline 3-200-019 & $6 / 13 / 2003$ & $10: 07$ & 1.95 & $<0.008$ \\
\hline $3-200-021$ & $6 / 13 / 2003$ & $15: 11$ & 2.16 & $<0.008$ \\
\hline 3-200-023 & $6 / 13 / 2003$ & 19:09 & 2.33 & $<0.008$ \\
\hline $3-200-025$ & $6 / 13 / 2003$ & $22: 40$ & 2.47 & $<0.008$ \\
\hline 3-200-027 & $6 / 14 / 2003$ & $6: 01$ & 2.78 & $<0.008$ \\
\hline $3-200-029$ & $6 / 14 / 2003$ & $9: 57$ & 2.94 & $<0.008$ \\
\hline $3-200-031$ & $6 / 14 / 2003$ & $15: 12$ & 3.16 & $<0.008$ \\
\hline $3-200-033$ & $6 / 14 / 2003$ & $19: 20$ & 3.33 & $<0.008$ \\
\hline 3-200-035 & $6 / 14 / 2003$ & $23: 00$ & 3.49 & $<0.008$ \\
\hline
\end{tabular}


Table A-2: Continued

\begin{tabular}{|c|c|c|c|c|}
\hline Sample Name & Date & Time & $\begin{array}{c}\text { Time elapsed } \\
\text { (days) }\end{array}$ & $\begin{array}{c}2,4,5-\mathrm{TFBA} \\
(\mathrm{mg} / \mathrm{L})\end{array}$ \\
\hline 3-200-037 & $6 / 15 / 2003$ & 6:01 & 3.78 & $<0.008$ \\
\hline $3-200-040$ & $6 / 15 / 2003$ & $20: 05$ & 4.36 & $<0.008$ \\
\hline 3-200-042 & $6 / 15 / 2003$ & $22: 43$ & 4.47 & $<0.008$ \\
\hline 3-200-045 & $6 / 16 / 2003$ & $10: 42$ & 4.97 & $<0.008$ \\
\hline $3-200-047$ & $6 / 16 / 2003$ & $15: 40$ & 5.18 & 0.002 \\
\hline 3-200-049 & $6 / 16 / 2003$ & $19: 06$ & 5.32 & 0.004 \\
\hline 3-200-053 & $6 / 17 / 2003$ & 5:06 & 5.74 & 0.007 \\
\hline 3-200-055 & $6 / 17 / 2003$ & $9: 12$ & 5.91 & 0.014 \\
\hline $3-200-057$ & $6 / 17 / 2003$ & 13:38 & 6.10 & 0.004 \\
\hline 3-200-059 & $6 / 17 / 2003$ & $18: 05$ & 6.28 & 0.014 \\
\hline 3-200-061 & $6 / 17 / 2003$ & $21: 16$ & 6.41 & 0.017 \\
\hline $3-200-063$ & $6 / 18 / 2003$ & $4: 45$ & 6.73 & 0.023 \\
\hline 3-200-065 & $6 / 18 / 2003$ & $8: 39$ & 6.89 & 0.019 \\
\hline $3-200-067$ & $6 / 18 / 2003$ & $15: 56$ & 7.19 & 0.031 \\
\hline 3-200-069 & $6 / 19 / 2003$ & $6: 45$ & 7.81 & 0.031 \\
\hline 3-200-071 & $6 / 19 / 2003$ & $10: 59$ & 7.99 & 0.040 \\
\hline 3-200-073 & $6 / 19 / 2003$ & $17: 35$ & 8.26 & 0.034 \\
\hline $3-200-075$ & $6 / 19 / 2003$ & $22: 20$ & 8.46 & 0.039 \\
\hline 3-200-077 & $6 / 20 / 2003$ & $6: 37$ & 8.80 & 0.037 \\
\hline 3-200-079 & $6 / 20 / 2003$ & $11: 29$ & 9.01 & 0.042 \\
\hline 3-200-081 & $6 / 20 / 2003$ & $17: 24$ & 9.25 & 0.039 \\
\hline 3-200-093 & $6 / 20 / 2003$ & $21: 23$ & 9.42 & 0.039 \\
\hline 3-200-097 & $6 / 21 / 2003$ & $6: 40$ & 9.81 & 0.046 \\
\hline 3-200-099 & $6 / 21 / 2003$ & $11: 05$ & 9.99 & 0.042 \\
\hline $3-200-101$ & $6 / 21 / 2003$ & $17: 22$ & 10.25 & 0.052 \\
\hline $3-200-103$ & $6 / 21 / 2003$ & $21: 20$ & 10.42 & 0.050 \\
\hline 3-200-105 & $6 / 22 / 2003$ & 7:02 & 10.82 & 0.059 \\
\hline $3-200-109$ & $6 / 22 / 2003$ & $10: 59$ & 10.99 & 0.064 \\
\hline $3-200-111$ & $6 / 22 / 2003$ & $17: 18$ & 11.25 & 0.063 \\
\hline $3-200-113$ & $6 / 22 / 2003$ & $21: 12$ & 11.41 & 0.071 \\
\hline $3-200-117$ & $6 / 23 / 2003$ & $7: 10$ & 11.83 & 0.071 \\
\hline $3-200-119$ & $6 / 23 / 2003$ & $11: 22$ & 12.00 & 0.080 \\
\hline 3-200-121 & $6 / 23 / 2003$ & $18: 00$ & 12.28 & 0.077 \\
\hline $3-200-123$ & $6 / 23 / 2003$ & $21: 10$ & 12.41 & 0.085 \\
\hline 3-200-125 & $6 / 24 / 2003$ & 7:09 & 12.83 & 0.084 \\
\hline $3-200-127$ & $6 / 24 / 2003$ & $15: 49$ & 13.19 & 0.091 \\
\hline 3-200-129 & $6 / 23 / 2003$ & 7:06 & 11.82 & 0.088 \\
\hline $3-200-131$ & $6 / 25 / 2003$ & $16: 24$ & 14.21 & 0.095 \\
\hline $3-200-133$ & $6 / 26 / 2003$ & $7: 12$ & 14.83 & 0.090 \\
\hline 3-200-137 & $6 / 30 / 2003$ & $15: 33$ & 19.18 & 0.090 \\
\hline 3-200-139 & $7 / 3 / 2003$ & $10: 09$ & 21.95 & 0.088 \\
\hline $3-200-143$ & $7 / 10 / 2003$ & $14: 52$ & 29.15 & 0.076 \\
\hline Tst2-200-001 & $8 / 1 / 2003$ & $12: 22$ & 51.04 & 0.049 \\
\hline
\end{tabular}


Table A-2: Continued

\begin{tabular}{|c|c|c|c|c|}
\hline Sample Name & Date & Time & $\begin{array}{c}\text { Time elapsed } \\
\text { (days) }\end{array}$ & $\begin{array}{c}2,4,5-\mathrm{TFBA} \\
(\mathrm{mg} / \mathrm{L})\end{array}$ \\
\hline Tst2-200-003 & $8 / 1 / 2003$ & $15: 32$ & 51.18 & 0.048 \\
\hline Tst2-200-007 & $8 / 1 / 2003$ & $18: 23$ & 51.29 & 0.048 \\
\hline Tst2-200-009 & $8 / 1 / 2003$ & 21:03 & 51.40 & 0.049 \\
\hline Tst2-200-013 & $8 / 1 / 2003$ & 23:45 & 51.52 & 0.048 \\
\hline Tst2-200-015 & $8 / 2 / 2003$ & $5: 20$ & 51.75 & 0.046 \\
\hline Tst2-200-019 & $8 / 2 / 2003$ & $8: 32$ & 51.88 & 0.044 \\
\hline Tst2-200-021 & $8 / 2 / 2003$ & $11: 41$ & 52.01 & 0.043 \\
\hline Tst2-200-025 & $8 / 2 / 2003$ & $17: 31$ & 52.26 & 0.041 \\
\hline Tst2-200-033 & $8 / 2 / 2003$ & $20: 51$ & 52.40 & 0.044 \\
\hline Tst2-200-037 & $8 / 2 / 2003$ & $22: 18$ & 52.46 & 0.034 \\
\hline Tst2-200-041 & $8 / 2 / 2003$ & $23: 48$ & 52.52 & 0.044 \\
\hline Tst2-200-045 & $8 / 3 / 2003$ & $5: 24$ & 52.75 & 0.041 \\
\hline Tst2-200-049 & $8 / 3 / 2003$ & $7: 19$ & 52.83 & 0.042 \\
\hline Tst2-200-133 & $8 / 5 / 2003$ & $12: 52$ & 55.06 & $<0.024$ \\
\hline Tst2-200-153 & $8 / 6 / 2003$ & $5: 50$ & 55.77 & $<0.024$ \\
\hline Tst2-200-157 & $8 / 6 / 2003$ & $7: 25$ & 55.84 & $<0.024$ \\
\hline Tst2-200-161 & 8/6/2003 & 9:36 & 55.93 & $<0.024$ \\
\hline Tst2-200-169 & $8 / 6 / 2003$ & $17: 28$ & 56.26 & $<0.024$ \\
\hline Tst2-200-173 & 8/6/2003 & $22: 00$ & 56.44 & $<0.024$ \\
\hline Tst2-200-177 & $8 / 6 / 2003$ & $23: 13$ & 56.50 & $<0.024$ \\
\hline Tst2-200-181 & $8 / 7 / 2003$ & $5: 14$ & 56.75 & $<0.024$ \\
\hline Tst2-200-185 & $8 / 7 / 2003$ & $8: 51$ & 56.90 & $<0.024$ \\
\hline Tst2-200-189 & $8 / 7 / 2003$ & $11: 54$ & 57.02 & $<0.024$ \\
\hline Tst2-200-193 & 8/7/2003 & $17: 45$ & 57.27 & $<0.024$ \\
\hline Tst2-200-201 & 8/7/2003 & $21: 38$ & 57.43 & $<0.024$ \\
\hline Tst2-200-221 & $8 / 8 / 2003$ & $12: 27$ & 58.05 & $<0.024$ \\
\hline Tst2-200-233 & $8 / 8 / 2003$ & 21:10 & 58.41 & $<0.024$ \\
\hline Tst2-200-237 & $8 / 8 / 2003$ & 22:38 & 58.47 & $<0.024$ \\
\hline Tst2-200-241 & $8 / 9 / 2003$ & $5: 32$ & 58.76 & $<0.024$ \\
\hline Tst2-200-245 & $8 / 9 / 2003$ & $8: 40$ & 58.89 & $<0.024$ \\
\hline Tst2-200-249 & $8 / 9 / 2003$ & $10: 40$ & 58.97 & $<0.024$ \\
\hline Tst2-200-253 & $8 / 9 / 2003$ & $12: 47$ & 59.06 & $<0.024$ \\
\hline Tst2-200-257 & $8 / 9 / 2003$ & $18: 00$ & 59.28 & $<0.024$ \\
\hline Tst2-200-261 & $8 / 9 / 2003$ & $18: 55$ & 59.32 & $<0.024$ \\
\hline Tst2-200-265 & 8/9/2003 & 20:29 & 59.38 & $<0.024$ \\
\hline Tst2-200-273 & $8 / 9 / 2003$ & $22: 55$ & 59.48 & $<0.024$ \\
\hline Tst2-200-277 & $8 / 8 / 2003$ & $20: 31$ & 58.38 & $<0.024$ \\
\hline Tst2-200-281 & $8 / 10 / 2003$ & $8: 43$ & 59.89 & $<0.024$ \\
\hline Tst2-200-285 & $8 / 10 / 2003$ & $10: 37$ & 59.97 & $<0.024$ \\
\hline Tst2-200-289 & 8/9/2003 & $21: 31$ & 59.42 & $<0.024$ \\
\hline Tst2-200-293 & $8 / 10 / 2003$ & $22: 31$ & 60.47 & $<0.024$ \\
\hline Tst2-200-294 & $8 / 10 / 2003$ & 19:02 & 60.32 & $<0.024$ \\
\hline Tst2-200-297 & $8 / 10 / 2003$ & 23:27 & 60.50 & $<0.024$ \\
\hline
\end{tabular}


Table A-2: Continued

\begin{tabular}{|c|c|c|c|c|}
\hline Sample Name & Date & Time & $\begin{array}{c}\text { Time elapsed } \\
\text { (days) }\end{array}$ & $\begin{array}{c}2,4,5-T F B A \\
(\mathrm{mg} / \mathrm{L})\end{array}$ \\
\hline Tst2-200-297 & $8 / 11 / 2003$ & 23:31 & 61.51 & $<0.024$ \\
\hline Tst2-200-301 & $8 / 10 / 2003$ & $21: 40$ & 60.43 & $<0.024$ \\
\hline Tst2-200-307 & $8 / 11 / 2003$ & $6: 20$ & 60.79 & $<0.024$ \\
\hline Tst2-200-310 & $8 / 11 / 2003$ & $8: 49$ & 60.90 & $<0.024$ \\
\hline Tst2-200-315 & $8 / 11 / 2003$ & $12: 18$ & 61.04 & $<0.024$ \\
\hline Tst2-200-318 & $8 / 11 / 2003$ & $17: 31$ & 61.26 & $<0.024$ \\
\hline Tst2-200-322 & $8 / 11 / 2003$ & $18: 42$ & 61.31 & $<0.024$ \\
\hline Tst2-200-326 & $8 / 11 / 2003$ & $20: 12$ & 61.37 & $<0.024$ \\
\hline Tst2-200-331 & $8 / 11 / 2003$ & $22: 36$ & 61.47 & $<0.024$ \\
\hline Tst2-200-335 & $8 / 12 / 2003$ & $6: 15$ & 61.79 & $<0.024$ \\
\hline Tst2-200-343 & $8 / 12 / 2003$ & $10: 55$ & 61.98 & $<0.024$ \\
\hline Tst2-200-359 & $8 / 13 / 2003$ & $5: 53$ & 62.77 & $<0.024$ \\
\hline Tst2-200-365 & $8 / 12 / 2003$ & $0: 31$ & 62.55 & $<0.024$ \\
\hline Tst2-200-369 & $8 / 13 / 2003$ & $1: 31$ & 63.59 & $<0.024$ \\
\hline Tst2-200-373 & $8 / 14 / 2003$ & $2: 31$ & 64.63 & $<0.024$ \\
\hline Tst2-200-375 & $8 / 15 / 2003$ & $3: 31$ & 65.67 & $<0.024$ \\
\hline Tst2-200-377 & $8 / 14 / 2003$ & 6:04 & 63.78 & $<0.024$ \\
\hline Tst2-200-380 & $8 / 14 / 2003$ & $8: 57$ & 63.90 & $<0.024$ \\
\hline Tst2-200-385 & $8 / 14 / 2003$ & $10: 38$ & 63.97 & $<0.024$ \\
\hline Tst2-200-387 & $8 / 14 / 2003$ & $17: 27$ & 64.25 & $<0.024$ \\
\hline Tst2-200-389 & $8 / 14 / 2003$ & $20: 27$ & 64.38 & $<0.024$ \\
\hline Tst2-200-393 & $8 / 14 / 2003$ & $22: 44$ & 64.48 & $<0.024$ \\
\hline Tst2-200-395 & $8 / 15 / 2003$ & $6: 12$ & 64.79 & $<0.024$ \\
\hline Tst2-200-398 & $8 / 15 / 2003$ & 8:09 & 64.87 & $<0.024$ \\
\hline Tst2-200-402 & $8 / 15 / 2003$ & 13:06 & 65.07 & $<0.024$ \\
\hline Tst2-200-405 & $8 / 15 / 2003$ & $17: 20$ & 65.25 & $<0.024$ \\
\hline Tst2-200-417 & $8 / 16 / 2003$ & $9: 17$ & 65.91 & $<0.024$ \\
\hline Tst2-200-423 & $8 / 16 / 2003$ & $17: 16$ & 66.25 & $<0.024$ \\
\hline Tst2-200-427 & $8 / 18 / 2003$ & $19: 20$ & 68.33 & $<0.024$ \\
\hline Tst2-200-429 & $8 / 18 / 2003$ & $20: 57$ & 68.40 & $<0.024$ \\
\hline Tst2-200-431 & $8 / 18 / 2003$ & $22: 50$ & 68.48 & $<0.024$ \\
\hline Tst2-200-435 & $8 / 19 / 2003$ & $7: 57$ & 68.86 & $<0.024$ \\
\hline Tst2-200-437 & $8 / 19 / 2003$ & $10: 29$ & 68.96 & $<0.024$ \\
\hline Tst2-200-441 & $8 / 19 / 2003$ & $14: 27$ & 69.13 & $<0.024$ \\
\hline Tst2-200-443 & $8 / 19 / 2003$ & $17: 41$ & 69.26 & $<0.024$ \\
\hline Tst2-200-447 & $8 / 19 / 2003$ & $20: 33$ & 69.38 & $<0.024$ \\
\hline Tst2-200-449 & $8 / 20 / 2003$ & $8: 32$ & 69.88 & $<0.024$ \\
\hline Tst2-200-453 & $8 / 20 / 2003$ & $11: 27$ & 70.00 & $<0.024$ \\
\hline Tst2-200-455 & $8 / 20 / 2003$ & $17: 43$ & 70.27 & $<0.024$ \\
\hline Tst2-200-459 & $8 / 20 / 2003$ & $20: 36$ & 70.39 & $<0.024$ \\
\hline Tst2-200-465 & $8 / 21 / 2003$ & $14: 30$ & 71.13 & $<0.024$ \\
\hline Tst2-200-467 & $8 / 22 / 2003$ & $10: 33$ & 71.97 & $<0.024$ \\
\hline Tst2-200-471 & $8 / 23 / 2003$ & $10: 03$ & 72.95 & $<0.024$ \\
\hline
\end{tabular}


Table A-2: Continued

\begin{tabular}{|c|c|c|c|c|}
\hline Sample Name & Date & Time & $\begin{array}{c}\text { Time elapsed } \\
\text { (days) }\end{array}$ & $\begin{array}{c}\mathbf{2 , 4 , 5 - T F B A ~} \\
\text { (mg/L) }\end{array}$ \\
\hline Tst2-200-473 & $8 / 25 / 2003$ & $8: 12$ & 74.87 & $<0.024$ \\
\hline Tst2-200-477 & $8 / 25 / 2003$ & $15: 15$ & 75.16 & $<0.024$ \\
\hline Tst2-200-479 & $8 / 26 / 2003$ & $9: 05$ & 75.91 & $<0.024$ \\
\hline Tst2-200-483 & $8 / 26 / 2003$ & $15: 19$ & 76.17 & $<0.024$ \\
\hline Tst2-200-489 & $8 / 27 / 2003$ & $14: 08$ & 77.12 & $<0.024$ \\
\hline Tst2-200-509 & $8 / 16 / 2003$ & $4: 31$ & 66.72 & $<0.024$ \\
\hline Tst2-200-513 & $8 / 17 / 2003$ & $5: 31$ & 67.76 & $<0.024$ \\
\hline Tst2-200-515 & $8 / 18 / 2003$ & $6: 31$ & 68.80 & $<0.024$ \\
\hline Tst2-200-519 & $8 / 19 / 2003$ & $7: 31$ & 69.84 & $<0.024$ \\
\hline Tst2-200-521 & $8 / 20 / 2003$ & $8: 31$ & 70.88 & $<0.024$ \\
\hline Tst2-200-525 & $8 / 21 / 2003$ & $9: 31$ & 71.92 & $<0.024$ \\
\hline Tst2-200-527 & $8 / 22 / 2003$ & $10: 31$ & 72.97 & $<0.024$ \\
\hline Tst2-200-531 & $8 / 23 / 2003$ & $11: 31$ & 74.01 & $<0.024$ \\
\hline
\end{tabular}

Table A-3: HPLC data from test 1, well 202

\begin{tabular}{|c|c|c|c|c|}
\hline Sample Name & Date & Time & $\begin{array}{l}\text { Time elapsed } \\
\text { (days) }\end{array}$ & $\begin{array}{c}2,4,5-\mathrm{TFBA} \\
(\mathrm{mg} / \mathrm{L})\end{array}$ \\
\hline 3-202-001 & $6 / 10 / 2003$ & $17: 45$ & -0.73 & $<0.008$ \\
\hline $3-202-004$ & $6 / 11 / 2003$ & $16: 50$ & 0.23 & $<0.008$ \\
\hline 3-202-006 & $6 / 11 / 2003$ & 19:39 & 0.35 & $<0.008$ \\
\hline $3-202-008$ & $6 / 11 / 2003$ & $23: 21$ & 0.50 & $<0.008$ \\
\hline 3-202-009 & $6 / 12 / 2003$ & $5: 25$ & 0.75 & $<0.008$ \\
\hline $3-202-011$ & $6 / 12 / 2003$ & $10: 40$ & 0.97 & $<0.008$ \\
\hline $3-202-013$ & $6 / 12 / 2003$ & $15: 29$ & 1.17 & $<0.008$ \\
\hline 3-202-015 & $6 / 12 / 2003$ & $19: 46$ & 1.35 & $<0.008$ \\
\hline 3-202-017 & $6 / 12 / 2003$ & $23: 16$ & 1.50 & $<0.008$ \\
\hline 3-202-019 & $6 / 13 / 2003$ & $6: 04$ & 1.78 & $<0.008$ \\
\hline 3-202-021 & $6 / 13 / 2003$ & $10: 16$ & 1.96 & $<0.008$ \\
\hline 3-202-023 & $6 / 13 / 2003$ & $15: 22$ & 2.17 & $<0.008$ \\
\hline $3-202-025$ & $6 / 13 / 2003$ & $19: 16$ & 2.33 & $<0.008$ \\
\hline 3-202-027 & $6 / 13 / 2003$ & $22: 50$ & 2.48 & $<0.008$ \\
\hline 3-202-029 & $6 / 14 / 2003$ & $6: 13$ & 2.79 & $<0.008$ \\
\hline $3-202-031$ & $6 / 14 / 2003$ & $10: 06$ & 2.95 & $<0.008$ \\
\hline 3-202-033 & $6 / 14 / 2003$ & $15: 20$ & 3.17 & $<0.008$ \\
\hline 3-202-035 & $6 / 14 / 2003$ & $19: 30$ & 3.34 & $<0.008$ \\
\hline 3-202-037 & $6 / 14 / 2003$ & 23:08 & 3.49 & $<0.008$ \\
\hline 3-202-039 & $6 / 15 / 2003$ & $6: 12$ & 3.79 & $<0.008$ \\
\hline 3-202-041 & $6 / 15 / 2003$ & $10: 11$ & 3.95 & $<0.008$ \\
\hline 3-202-044 & $6 / 15 / 2003$ & $15: 15$ & 4.16 & $<0.008$ \\
\hline 3-202-046 & $6 / 15 / 2003$ & $20: 13$ & 4.37 & $<0.008$ \\
\hline $3-202-048$ & $6 / 15 / 2003$ & $22: 50$ & 4.48 & $<0.008$ \\
\hline
\end{tabular}


Table A-3: Continued

\begin{tabular}{|c|c|c|c|c|}
\hline Sample Name & Date & Time & $\begin{array}{c}\text { Time elapsed } \\
\text { (days) }\end{array}$ & $\begin{array}{c}\begin{array}{c}2,4,5-T F B A \\
(\mathrm{mg} / \mathrm{L})\end{array} \\
\end{array}$ \\
\hline 3-202-051 & $6 / 16 / 2003$ & $10: 31$ & 4.97 & $<0.008$ \\
\hline $3-202-053$ & $6 / 16 / 2003$ & $15: 50$ & 5.19 & 0.004 \\
\hline 3-202-055 & $6 / 16 / 2003$ & $19: 15$ & 5.33 & 0.005 \\
\hline 3-202-057 & $6 / 16 / 2003$ & 23:00 & 5.49 & 0.006 \\
\hline 3-202-061 & $6 / 17 / 2003$ & $8: 59$ & 5.90 & 0.014 \\
\hline 3-202-063 & $6 / 17 / 2003$ & $13: 50$ & 6.10 & 0.015 \\
\hline 3-202-065 & $6 / 17 / 2003$ & $18: 15$ & 6.29 & 0.017 \\
\hline 3-202-067 & $6 / 17 / 2003$ & $21: 26$ & 6.42 & 0.021 \\
\hline 3-202-069 & $6 / 18 / 2003$ & $5: 17$ & 6.75 & 0.028 \\
\hline 3-202-071 & $6 / 18 / 2003$ & $10: 07$ & 6.95 & 0.030 \\
\hline 3-202-073 & $6 / 18 / 2003$ & $16: 06$ & 7.20 & 0.035 \\
\hline 3-202-075 & $6 / 18 / 2003$ & $22: 23$ & 7.46 & 0.037 \\
\hline 3-202-077 & $6 / 19 / 2003$ & $6: 58$ & 7.82 & 0.054 \\
\hline 3-202-079 & $6 / 19 / 2003$ & $10: 48$ & 7.98 & 0.056 \\
\hline 3-202-081 & $6 / 19 / 2003$ & $17: 42$ & 8.27 & 0.062 \\
\hline 3-202-083 & $6 / 19 / 2003$ & $22: 27$ & 8.46 & 0.065 \\
\hline 3-202-085 & $6 / 20 / 2003$ & $6: 46$ & 8.81 & 0.074 \\
\hline 3-202-087 & $6 / 20 / 2003$ & $11: 38$ & 9.01 & 0.081 \\
\hline 3-202-089 & $6 / 20 / 2003$ & $17: 32$ & 9.26 & 0.085 \\
\hline 3-202-091 & $6 / 20 / 2003$ & $21: 32$ & 9.43 & 0.090 \\
\hline 3-202-095 & $6 / 21 / 2003$ & $6: 51$ & 9.81 & 0.098 \\
\hline 3-202-097 & $6 / 21 / 2003$ & $11: 16$ & 10.00 & 0.102 \\
\hline 3-202-099 & $6 / 21 / 2003$ & $17: 32$ & 10.26 & 0.105 \\
\hline 3-202-101 & $6 / 21 / 2003$ & $21: 29$ & 10.42 & 0.107 \\
\hline $3-202-103$ & $6 / 22 / 2003$ & $11: 08$ & 10.99 & 0.111 \\
\hline 3-202-105 & $6 / 22 / 2003$ & $17: 27$ & 11.25 & 0.115 \\
\hline 3-202-107 & $6 / 22 / 2003$ & $21: 20$ & 11.42 & 0.115 \\
\hline 3-202-115 & $6 / 23 / 2003$ & $18: 07$ & 12.28 & 0.114 \\
\hline 3-202-119 & $6 / 24 / 2003$ & $7: 20$ & 12.83 & 0.114 \\
\hline 3-202-121 & $6 / 24 / 2003$ & $15: 39$ & 13.18 & 0.111 \\
\hline $3-202-123$ & $6 / 25 / 2003$ & $7: 43$ & 13.85 & 0.113 \\
\hline 3-202-125 & $6 / 25 / 2003$ & $16: 10$ & 14.20 & 0.111 \\
\hline $3-202-127$ & $6 / 26 / 2003$ & $7: 30$ & 14.84 & 0.110 \\
\hline $3-202-129$ & $6 / 26 / 2003$ & $15: 17$ & 15.16 & 0.110 \\
\hline 3-202-131 & $6 / 30 / 2003$ & $15: 41$ & 19.18 & 0.092 \\
\hline 3-202-133 & $7 / 3 / 2003$ & 9:56 & 21.94 & 0.082 \\
\hline 3-202-135 & $7 / 8 / 2003$ & $10: 51$ & 26.98 & 0.065 \\
\hline Tst2-202-001 & $8 / 1 / 2003$ & $12: 31$ & 51.05 & 0.027 \\
\hline Tst2-202-003 & $8 / 1 / 2003$ & $15: 42$ & 51.18 & $<0.024$ \\
\hline Tst2-202-007 & $8 / 1 / 2003$ & $18: 02$ & 51.28 & 0.027 \\
\hline Tst2-202-009 & $8 / 1 / 2003$ & $20: 52$ & 51.40 & 0.027 \\
\hline Tst2-202-013 & $8 / 1 / 2003$ & 23:32 & 51.51 & $<0.024$ \\
\hline Tst2-202-015 & $8 / 2 / 2003$ & $5: 31$ & 51.76 & 0.026 \\
\hline
\end{tabular}


Table A-3: Continued

\begin{tabular}{|c|c|c|c|c|}
\hline Sample Name & Date & Time & $\begin{array}{c}\text { Time elapsed } \\
\text { (days) }\end{array}$ & $\begin{array}{c}2,4,5-T F B A \\
(\mathrm{mg} / \mathrm{L})\end{array}$ \\
\hline Tst2-202-021 & $8 / 2 / 2003$ & $11: 51$ & 52.02 & $<0.024$ \\
\hline Tst2-202-025 & $8 / 2 / 2003$ & $17: 25$ & 52.25 & $<0.024$ \\
\hline Tst2-202-027 & $8 / 2 / 2003$ & $21: 02$ & 52.40 & 0.026 \\
\hline Tst2-202-031 & $8 / 2 / 2003$ & 23:16 & 52.50 & 0.024 \\
\hline Tst2-202-033 & $8 / 3 / 2003$ & $5: 35$ & 52.76 & 0.024 \\
\hline Tst2-202-039 & $8 / 3 / 2003$ & $12: 54$ & 53.07 & $<0.024$ \\
\hline Tst2-202-043 & $8 / 3 / 2003$ & $17: 53$ & 53.27 & $<0.024$ \\
\hline Tst2-202-045 & $8 / 3 / 2003$ & $20: 59$ & 53.40 & 0.024 \\
\hline Tst2-202-049 & $8 / 3 / 2003$ & $23: 23$ & 53.50 & 0.023 \\
\hline Tst2-202-051 & $8 / 4 / 2003$ & $6: 05$ & 53.78 & 0.026 \\
\hline Tst2-202-055 & $8 / 4 / 2003$ & $8: 36$ & 53.89 & 0.027 \\
\hline Tst2-202-059 & $8 / 4 / 2003$ & $11: 07$ & 53.99 & 0.028 \\
\hline Tst2-202-065 & $8 / 4 / 2003$ & $20: 31$ & 54.38 & 0.026 \\
\hline Tst2-202-071 & $8 / 5 / 2003$ & $6: 05$ & 54.78 & 0.027 \\
\hline Tst2-202-073 & $8 / 5 / 2003$ & $8: 57$ & 54.90 & 0.026 \\
\hline Tst2-202-077 & $8 / 5 / 2003$ & $14: 08$ & 55.12 & 0.027 \\
\hline Tst2-202-081 & $8 / 5 / 2003$ & $17: 46$ & 55.27 & 0.027 \\
\hline Tst2-202-085 & $8 / 5 / 2003$ & $19: 00$ & 55.32 & 0.029 \\
\hline Tst2-202-089 & $8 / 5 / 2003$ & $21: 35$ & 55.43 & 0.027 \\
\hline Tst2-202-097 & $8 / 6 / 2003$ & $6: 20$ & 55.79 & 0.031 \\
\hline Tst2-202-099 & $8 / 6 / 2003$ & $7: 40$ & 55.85 & 0.033 \\
\hline Tst2-202-103 & $8 / 6 / 2003$ & $9: 48$ & 55.94 & 0.033 \\
\hline Tst2-202-107 & $8 / 6 / 2003$ & 13:08 & 56.08 & 0.031 \\
\hline Tst2-202-111 & $8 / 6 / 2003$ & $17: 48$ & 56.27 & 0.032 \\
\hline Tst2-202-115 & 8/6/2003 & $21: 37$ & 56.43 & 0.032 \\
\hline Tst2-202-117 & $8 / 6 / 2003$ & 23:21 & 56.50 & 0.033 \\
\hline Tst2-202-121 & $8 / 7 / 2003$ & $5: 25$ & 56.75 & 0.031 \\
\hline Tst2-202-125 & $8 / 7 / 2003$ & 9:01 & 56.90 & 0.030 \\
\hline Tst2-202-129 & $8 / 7 / 2003$ & $12: 30$ & 57.05 & 0.031 \\
\hline Tst2-202-133 & $8 / 7 / 2003$ & $18: 16$ & 57.29 & 0.031 \\
\hline Tst2-202-137 & $8 / 7 / 2003$ & $20: 48$ & 57.39 & 0.030 \\
\hline Tst2-202-145 & $8 / 8 / 2003$ & $5: 56$ & 57.78 & 0.026 \\
\hline Tst2-202-153 & $8 / 8 / 2003$ & $10: 18$ & 57.96 & 0.027 \\
\hline Tst2-202-161 & $8 / 8 / 2003$ & $17: 53$ & 58.27 & 0.025 \\
\hline Tst2-202-165 & 8/8/2003 & $21: 20$ & 58.42 & 0.026 \\
\hline Tst2-202-169 & $8 / 8 / 2003$ & $22: 46$ & 58.48 & 0.029 \\
\hline Tst2-202-175 & $8 / 9 / 2003$ & $6: 00$ & 58.78 & 0.029 \\
\hline Tst2-202-179 & $8 / 9 / 2003$ & $11: 55$ & 59.02 & 0.026 \\
\hline Tst2-202-183 & 8/9/2003 & $18: 20$ & 59.29 & $<0.024$ \\
\hline Tst2-202-187 & 8/9/2003 & $20: 35$ & 59.39 & 0.025 \\
\hline Tst2-202-191 & $8 / 9 / 2003$ & 23:04 & 59.49 & $<0.024$ \\
\hline Tst2-202-195 & $8 / 10 / 2003$ & $5: 54$ & 59.77 & $<0.024$ \\
\hline
\end{tabular}


Table A-3: Continued

\begin{tabular}{|c|c|c|c|c|}
\hline Sample Name & Date & Time & $\begin{array}{c}\text { Time elapsed } \\
\text { (days) }\end{array}$ & $\begin{array}{c}2,4,5-T F B A \\
(\mathrm{mg} / \mathrm{L})\end{array}$ \\
\hline Tst2-202-199 & $8 / 10 / 2003$ & $8: 55$ & 59.90 & $<0.024$ \\
\hline Tst2-202-201 & $8 / 10 / 2003$ & $12: 17$ & 60.04 & 0.025 \\
\hline Tst2-202-201 & $8 / 10 / 2003$ & $12: 17$ & 60.04 & $<0.024$ \\
\hline Tst2-202-205 & $8 / 10 / 2003$ & $19: 10$ & 60.33 & 0.024 \\
\hline Tst2-202-205 & $8 / 10 / 2003$ & $19: 10$ & 60.33 & 0.024 \\
\hline Tst2-202-209 & $8 / 11 / 2003$ & $22: 46$ & 61.48 & 0.025 \\
\hline Tst2-202-211 & $8 / 11 / 2003$ & $22: 46$ & 61.48 & $<0.024$ \\
\hline Tst2-202-213 & $8 / 11 / 2003$ & $6: 40$ & 60.81 & 0.023 \\
\hline Tst2-202-217 & $8 / 11 / 2003$ & $22: 46$ & 61.48 & $<0.024$ \\
\hline Tst2-202-219 & $8 / 11 / 2003$ & $14: 40$ & 61.14 & 0.022 \\
\hline Tst2-202-219 & $8 / 11 / 2003$ & $14: 40$ & 61.14 & $<0.024$ \\
\hline Tst2-202-221 & $8 / 11 / 2003$ & $14: 40$ & 61.14 & $<0.024$ \\
\hline Tst2-202-231 & $8 / 12 / 2003$ & $20: 36$ & 62.39 & $<0.024$ \\
\hline Tst2-202-241 & $8 / 13 / 2003$ & $6: 00$ & 62.78 & $<0.024$ \\
\hline Tst2-202-247 & $8 / 13 / 2003$ & $7: 10$ & 62.83 & $<0.024$ \\
\hline Tst2-202-253 & $8 / 13 / 2003$ & $11: 13$ & 63.00 & $<0.024$ \\
\hline Tst2-202-257 & $8 / 13 / 2003$ & $17: 34$ & 63.26 & $<0.024$ \\
\hline Tst2-202-263 & $8 / 13 / 2003$ & $20: 27$ & 63.38 & $<0.024$ \\
\hline Tst2-202-267 & $8 / 13 / 2003$ & $22: 11$ & 63.45 & $<0.024$ \\
\hline Tst2-202-273 & $8 / 14 / 2003$ & $6: 10$ & 63.78 & 0.019 \\
\hline Tst2-202-277 & $8 / 14 / 2003$ & 7:02 & 63.82 & 0.020 \\
\hline Tst2-202-281 & $8 / 14 / 2003$ & $9: 15$ & 63.91 & 0.019 \\
\hline Tst2-202-287 & $8 / 14 / 2003$ & $11: 05$ & 63.99 & 0.018 \\
\hline Tst2-202-289 & $8 / 14 / 2003$ & $17: 14$ & 64.25 & 0.018 \\
\hline Tst2-202-293 & $8 / 14 / 2003$ & $18: 40$ & 64.31 & 0.018 \\
\hline Tst2-202-297 & $8 / 14 / 2003$ & $20: 37$ & 64.39 & 0.018 \\
\hline Tst2-202-301 & $8 / 14 / 2003$ & $22: 55$ & 64.48 & 0.017 \\
\hline Tst2-202-305 & $8 / 15 / 2003$ & $6: 20$ & 64.79 & 0.018 \\
\hline Tst2-202-309 & $8 / 15 / 2003$ & $8: 17$ & 64.87 & 0.018 \\
\hline Tst2-202-313 & $8 / 15 / 2003$ & $13: 13$ & 65.08 & 0.017 \\
\hline Tst2-202-317 & $8 / 15 / 2003$ & $17: 34$ & 65.26 & $<0.024$ \\
\hline Tst2-202-321 & $8 / 15 / 2003$ & $19: 55$ & 65.36 & $<0.024$ \\
\hline Tst2-202-325 & $8 / 15 / 2003$ & $22: 51$ & 65.48 & $<0.024$ \\
\hline Tst2-202-329 & $8 / 16 / 2003$ & 7:01 & 65.82 & $<0.024$ \\
\hline Tst2-202-331 & $8 / 16 / 2003$ & $8: 15$ & 65.87 & $<0.024$ \\
\hline Tst2-202-335 & $8 / 16 / 2003$ & 9:30 & 65.92 & $<0.024$ \\
\hline Tst2-202-337 & $8 / 16 / 2003$ & 11:11 & 65.99 & $<0.024$ \\
\hline Tst2-202-341 & $8 / 16 / 2003$ & $17: 27$ & 66.25 & 0.016 \\
\hline Tst2-202-343 & $8 / 16 / 2003$ & $20: 17$ & 66.37 & $<0.024$ \\
\hline Tst2-202-349 & $8 / 17 / 2003$ & $7: 03$ & 66.82 & 0.016 \\
\hline Tst2-202-353 & $8 / 17 / 2003$ & $8: 55$ & 66.90 & $<0.024$ \\
\hline
\end{tabular}


Table A-3: Continued

\begin{tabular}{|c|c|c|c|c|}
\hline Sample Name & Date & Time & $\begin{array}{c}\text { Time elapsed } \\
\text { (days) }\end{array}$ & $\begin{array}{c}2,4,5-T F B A \\
(\mathrm{mg} / \mathrm{L})\end{array}$ \\
\hline Tst2-202-355 & $8 / 17 / 2003$ & $10: 05$ & 66.95 & $<0.024$ \\
\hline Tst2-202-356 & $8 / 17 / 2003$ & $10: 05$ & 66.95 & $<0.024$ \\
\hline Tst2-202-359 & $8 / 17 / 2003$ & $11: 25$ & 67.00 & $<0.024$ \\
\hline Tst2-202-361 & $8 / 17 / 2003$ & $17: 44$ & 67.27 & $<0.024$ \\
\hline Tst2-202-365 & $8 / 17 / 2003$ & $20: 31$ & 67.38 & $<0.024$ \\
\hline Tst2-202-371 & $8 / 18 / 2003$ & $6: 20$ & 67.79 & 0.015 \\
\hline Tst2-202-375 & $8 / 18 / 2003$ & $9: 54$ & 67.94 & 0.016 \\
\hline Tst2-202-377 & $8 / 18 / 2003$ & $13: 11$ & 68.08 & $<0.024$ \\
\hline Tst2-202-379 & $8 / 18 / 2003$ & $19: 43$ & 68.35 & $<0.024$ \\
\hline Tst2-202-383 & $8 / 18 / 2003$ & $21: 03$ & 68.40 & 0.017 \\
\hline Tst2-202-385 & $8 / 18 / 2003$ & $22: 57$ & 68.48 & 0.017 \\
\hline Tst2-202-389 & $8 / 19 / 2003$ & $8: 48$ & 68.89 & $<0.024$ \\
\hline Tst2-202-395 & $8 / 19 / 2003$ & $17: 56$ & 69.28 & 0.016 \\
\hline Tst2-202-397 & $8 / 19 / 2003$ & $20: 42$ & 69.39 & 0.017 \\
\hline Tst2-202-401 & $8 / 20 / 2003$ & $10: 01$ & 69.95 & 0.017 \\
\hline Tst2-202-403 & $8 / 20 / 2003$ & $11: 54$ & 70.02 & $<0.024$ \\
\hline Tst2-202-407 & $8 / 20 / 2003$ & $17: 55$ & 70.27 & 0.016 \\
\hline Tst2-202-409 & $8 / 20 / 2003$ & $20: 45$ & 70.39 & 0.017 \\
\hline Tst2-202-413 & $8 / 21 / 2003$ & $9: 19$ & 70.92 & 0.018 \\
\hline Tst2-202-415 & $8 / 21 / 2003$ & $15: 00$ & 71.15 & 0.017 \\
\hline Tst2-202-419 & $8 / 22 / 2003$ & 11:09 & 71.99 & 0.017 \\
\hline Tst2-202-421 & $8 / 23 / 2003$ & $10: 37$ & 72.97 & 0.017 \\
\hline Tst2-202-425 & $8 / 25 / 2003$ & $8: 43$ & 74.89 & 0.018 \\
\hline Tst2-202-427 & $8 / 25 / 2003$ & $15: 35$ & 75.18 & 0.016 \\
\hline Tst2-202-431 & $8 / 26 / 2003$ & $9: 41$ & 75.93 & 0.016 \\
\hline Tst2-202-433 & $8 / 26 / 2003$ & $15: 42$ & 76.18 & 0.016 \\
\hline Tst2-202-439 & $8 / 27 / 2003$ & $14: 32$ & 77.13 & $<0.024$ \\
\hline Tst2-202-443 & $8 / 28 / 2003$ & $10: 12$ & 77.95 & $<0.024$ \\
\hline Tst2-202-445 & $8 / 28 / 2003$ & $15: 43$ & 78.18 & $<0.024$ \\
\hline Tst2-202-449 & $8 / 29 / 2003$ & $15: 20$ & 79.17 & $<0.024$ \\
\hline Tst2-202-455 & $9 / 3 / 2003$ & $12: 35$ & 84.05 & $<0.024$ \\
\hline Tst2-202-459 & $9 / 4 / 2003$ & $14: 38$ & 85.14 & $<0.024$ \\
\hline Tst2-202-461 & $9 / 8 / 2003$ & $13: 48$ & 89.10 & $<0.024$ \\
\hline Tst2-202-465 & 9/9/2003 & $11: 23$ & 90.00 & $<0.024$ \\
\hline Tst2-202-467 & $9 / 10 / 2003$ & $11: 25$ & 91.00 & $<0.024$ \\
\hline Tst2-202-471 & $9 / 11 / 2003$ & $11: 25$ & 92.00 & $<0.024$ \\
\hline Tst2-202-479 & 9/18/2003 & $10: 48$ & 98.98 & $<0.024$ \\
\hline Tst2-202-483 & 9/22/2003 & $15: 26$ & 103.17 & $<0.024$ \\
\hline Tst2-202-489 & $9 / 25 / 2003$ & $15: 04$ & 106.16 & $<0.024$ \\
\hline
\end{tabular}


Table A-4: HPLC data from test 1, well 210

\begin{tabular}{|c|c|c|c|c|}
\hline Sample Name & Date & Time & $\begin{array}{l}\text { Time elapsed } \\
\text { (days) }\end{array}$ & $\begin{array}{c}2,4,5-\mathrm{TFBA} \\
(\mathrm{mg} / \mathrm{L})\end{array}$ \\
\hline $3-210-004$ & $6 / 11 / 2003$ & $11: 39$ & 0.013 & $<0.008$ \\
\hline 3-210-005 & $6 / 11 / 2003$ & $12: 28$ & 0.047 & $<0.008$ \\
\hline $3-210-007$ & $6 / 11 / 2003$ & $13: 52$ & 0.106 & $<0.008$ \\
\hline 3-210-009 & $6 / 11 / 2003$ & $14: 00$ & 0.111 & $<0.008$ \\
\hline 3-210-012 & $6 / 11 / 2003$ & $14: 52$ & 0.147 & $<0.008$ \\
\hline 3-210-014 & $6 / 11 / 2003$ & $16: 04$ & 0.197 & $<0.008$ \\
\hline 3-210-015 & $6 / 11 / 2003$ & $18: 12$ & 0.286 & $<0.008$ \\
\hline 3-210-018 & $6 / 11 / 2003$ & $20: 09$ & 0.367 & $<0.008$ \\
\hline $3-210-020$ & $6 / 11 / 2003$ & $22: 09$ & 0.451 & $<0.008$ \\
\hline 3-210-022 & $6 / 11 / 2003$ & $23: 49$ & 0.520 & $<0.008$ \\
\hline 3-210-023 & $6 / 12 / 2003$ & 4:08 & 0.700 & $<0.008$ \\
\hline 3-210-025 & $6 / 12 / 2003$ & $5: 59$ & 0.777 & $<0.008$ \\
\hline 3-210-027 & $6 / 12 / 2003$ & $7: 55$ & 0.858 & $<0.008$ \\
\hline 3-210-029 & $6 / 12 / 2003$ & $9: 56$ & 0.942 & $<0.008$ \\
\hline 3-210-031 & $6 / 12 / 2003$ & $12: 38$ & 1.054 & $<0.008$ \\
\hline 3-210-033 & $6 / 12 / 2003$ & $14: 00$ & 1.111 & 0.003 \\
\hline 3-210-035 & $6 / 12 / 2003$ & $16: 09$ & 1.201 & 0.025 \\
\hline 3-210-037 & $6 / 12 / 2003$ & $18: 05$ & 1.281 & 0.057 \\
\hline 3-210-039 & $6 / 12 / 2003$ & $20: 14$ & 1.371 & 0.097 \\
\hline 3-210-041 & $6 / 12 / 2003$ & $23: 42$ & 1.515 & 0.227 \\
\hline 3-210-043 & $6 / 12 / 2003$ & $22: 12$ & 1.453 & 0.167 \\
\hline 3-210-045 & $6 / 13 / 2003$ & $4: 11$ & 1.702 & 0.444 \\
\hline 3-210-047 & $6 / 13 / 2003$ & $6: 25$ & 1.795 & 0.556 \\
\hline 3-210-049 & $6 / 13 / 2003$ & $8: 29$ & 1.881 & 0.658 \\
\hline 3-210-051 & $6 / 13 / 2003$ & $10: 35$ & 1.969 & 0.748 \\
\hline 3-210-053 & $6 / 13 / 2003$ & $12: 38$ & 2.054 & 0.842 \\
\hline 3-210-054 & $6 / 13 / 2003$ & $12: 38$ & 2.054 & 0.790 \\
\hline 3-210-055 & $6 / 13 / 2003$ & $14: 42$ & 2.140 & 0.864 \\
\hline 3-210-057 & $6 / 13 / 2003$ & $16: 10$ & 2.201 & 0.917 \\
\hline 3-210-059 & $6 / 13 / 2003$ & 18:06 & 2.282 & 0.959 \\
\hline $3-210-061$ & $6 / 13 / 2003$ & $20: 06$ & 2.365 & 0.992 \\
\hline 3-210-063 & $6 / 13 / 2003$ & $22: 09$ & 2.451 & 1.048 \\
\hline 3-210-065 & $6 / 13 / 2003$ & $23: 30$ & 2.507 & 1.056 \\
\hline 3-210-067 & $6 / 14 / 2003$ & $4: 11$ & 2.702 & 1.068 \\
\hline 3-210-069 & $6 / 14 / 2003$ & $6: 31$ & 2.799 & 1.024 \\
\hline 3-210-071 & $6 / 14 / 2003$ & $8: 29$ & 2.881 & 1.006 \\
\hline $3-210-073$ & $6 / 14 / 2003$ & $10: 31$ & 2.966 & 0.969 \\
\hline 3-210-075 & $6 / 14 / 2003$ & $12: 27$ & 3.047 & 0.940 \\
\hline 3-210-077 & $6 / 14 / 2003$ & $14: 40$ & 3.139 & 0.906 \\
\hline 3-210-079 & $6 / 14 / 2003$ & $16: 06$ & 3.199 & 0.881 \\
\hline $3-210-083$ & $6 / 14 / 2003$ & $20: 10$ & 3.368 & 0.823 \\
\hline
\end{tabular}


Table A-4: Continued

\begin{tabular}{|c|c|c|c|c|}
\hline Sample Name & Date & Time & $\begin{array}{c}\text { Time elapsed } \\
\text { (days) }\end{array}$ & $\begin{array}{c}2,4,5-T F B A \\
(\mathrm{mg} / \mathrm{L})\end{array}$ \\
\hline 3-210-085 & $6 / 14 / 2003$ & 22:00 & 3.444 & 0.794 \\
\hline 3-210-087 & $6 / 14 / 2003$ & 23:37 & 3.512 & 0.767 \\
\hline 3-210-089 & $6 / 15 / 2003$ & $4: 16$ & 3.706 & 0.699 \\
\hline 3-210-091 & $6 / 15 / 2003$ & $6: 33$ & 3.801 & 0.669 \\
\hline 3-210-093 & $6 / 15 / 2003$ & $8: 30$ & 3.882 & 0.642 \\
\hline 3-210-095 & $6 / 15 / 2003$ & $10: 34$ & 3.968 & 0.614 \\
\hline 3-210-098 & $6 / 15 / 2003$ & $12: 20$ & 4.042 & 0.561 \\
\hline 3-210-099 & $6 / 15 / 2003$ & $14: 50$ & 4.146 & 0.558 \\
\hline 3-210-102 & $6 / 15 / 2003$ & $16: 05$ & 4.198 & 0.553 \\
\hline 3-210-104 & $6 / 15 / 2003$ & 18:09 & 4.284 & 0.529 \\
\hline 3-210-108 & $6 / 15 / 2003$ & $22: 14$ & 4.454 & 0.483 \\
\hline $3-210-110$ & $6 / 15 / 2003$ & $23: 15$ & 4.497 & 0.469 \\
\hline 3-210-112 & $6 / 16 / 2003$ & $4: 30$ & 4.715 & 0.387 \\
\hline 3-210-115 & $6 / 16 / 2003$ & $8: 10$ & 4.868 & 0.376 \\
\hline 3-210-117 & $6 / 16 / 2003$ & $10: 07$ & 4.949 & 0.351 \\
\hline $3-210-119$ & $6 / 16 / 2003$ & $11: 59$ & 5.027 & 0.335 \\
\hline 3-210-121 & $6 / 16 / 2003$ & $14: 56$ & 5.150 & 0.322 \\
\hline 3-210-127 & $6 / 16 / 2003$ & $20: 47$ & 5.394 & 0.280 \\
\hline 3-210-129 & $6 / 16 / 2003$ & $22: 15$ & 5.455 & 0.281 \\
\hline 3-210-131 & $6 / 16 / 2003$ & 23:45 & 5.517 & 0.269 \\
\hline 3-210-133 & $6 / 17 / 2003$ & $4: 19$ & 5.708 & 0.237 \\
\hline 3-210-135 & $6 / 17 / 2003$ & $6: 28$ & 5.797 & 0.233 \\
\hline 3-210-137 & $6 / 17 / 2003$ & $8: 33$ & 5.884 & 0.217 \\
\hline 3-210-139 & $6 / 17 / 2003$ & $10: 27$ & 5.963 & 0.209 \\
\hline 3-210-141 & $6 / 17 / 2003$ & $12: 30$ & 6.049 & 0.220 \\
\hline $3-210-143$ & $6 / 17 / 2003$ & $14: 18$ & 6.124 & 0.190 \\
\hline 3-210-145 & $6 / 17 / 2003$ & $17: 28$ & 6.256 & 0.208 \\
\hline 3-210-147 & $6 / 17 / 2003$ & 19:09 & 6.326 & 0.185 \\
\hline 3-210-149 & $6 / 17 / 2003$ & $20: 45$ & 6.392 & 0.180 \\
\hline 3-210-151 & $6 / 17 / 2003$ & $22: 13$ & 6.453 & 0.161 \\
\hline 3-210-155 & $6 / 18 / 2003$ & $4: 19$ & 6.708 & 0.155 \\
\hline 3-210-157 & $6 / 18 / 2003$ & $6: 14$ & 6.788 & 0.148 \\
\hline 3-210-159 & $6 / 18 / 2003$ & $8: 10$ & 6.868 & 0.142 \\
\hline 3-210-161 & $6 / 18 / 2003$ & $10: 17$ & 6.956 & 0.143 \\
\hline 3-210-163 & $6 / 18 / 2003$ & $14: 54$ & 7.149 & 0.131 \\
\hline 3-210-164 & $6 / 18 / 2003$ & $18: 08$ & 7.283 & 0.126 \\
\hline 3-210-167 & 6/18/2003 & 21:21 & 7.417 & 0.116 \\
\hline 3-210-169 & $6 / 18 / 2003$ & 23:09 & 7.492 & 0.137 \\
\hline 3-210-171 & $6 / 19 / 2003$ & $5: 29$ & 7.756 & 0.126 \\
\hline 3-210-173 & $6 / 19 / 2003$ & $9: 18$ & 7.915 & 0.119 \\
\hline 3-210-175 & $6 / 19 / 2003$ & $12: 48$ & 8.061 & 0.115 \\
\hline 3-210-179 & $6 / 19 / 2003$ & 22:48 & 8.478 & 0.102 \\
\hline 3-210-181 & $6 / 19 / 2003$ & $19: 10$ & 8.326 & 0.106 \\
\hline
\end{tabular}


Table A-4: Continued

\begin{tabular}{|c|c|c|c|c|}
\hline Sample Name & Date & Time & $\begin{array}{c}\text { Time elapsed } \\
\text { (days) }\end{array}$ & $\begin{array}{c}\begin{array}{c}2,4,5-T F B A \\
(\mathrm{mg} / \mathrm{L})\end{array} \\
\end{array}$ \\
\hline $3-210-183$ & $6 / 20 / 2003$ & $5: 31$ & 8.758 & 0.094 \\
\hline $3-210-185$ & $6 / 20 / 2003$ & 7:09 & 8.826 & 0.094 \\
\hline $3-210-187$ & $6 / 20 / 2003$ & 9:05 & 8.906 & 0.091 \\
\hline 3-210-189 & $6 / 20 / 2003$ & $11: 53$ & 9.023 & 0.088 \\
\hline 3-210-191 & $6 / 20 / 2003$ & $16: 58$ & 9.235 & 0.083 \\
\hline $3-210-193$ & $6 / 20 / 2003$ & $19: 17$ & 9.331 & 0.079 \\
\hline 3-210-195 & $6 / 20 / 2003$ & $21: 55$ & 9.441 & 0.077 \\
\hline 3-210-197 & $6 / 21 / 2003$ & $5: 37$ & 9.762 & 0.071 \\
\hline 3-210-199 & $6 / 21 / 2003$ & 9:06 & 9.907 & 0.069 \\
\hline $3-210-201$ & $6 / 21 / 2003$ & $11: 50$ & 10.021 & 0.066 \\
\hline $3-210-203$ & $6 / 21 / 2003$ & $16: 54$ & 10.232 & 0.062 \\
\hline $3-210-205$ & $6 / 21 / 2003$ & $18: 38$ & 10.304 & 0.062 \\
\hline $3-210-207$ & $6 / 21 / 2003$ & $21: 55$ & 10.441 & 0.060 \\
\hline $3-210-211$ & $6 / 22 / 2003$ & $6: 16$ & 10.789 & 0.055 \\
\hline $3-210-213$ & $6 / 22 / 2003$ & $8: 59$ & 10.902 & 0.055 \\
\hline $3-210-215$ & $6 / 22 / 2003$ & $11: 49$ & 11.020 & 0.053 \\
\hline $3-210-217$ & $6 / 22 / 2003$ & $16: 51$ & 11.230 & 0.051 \\
\hline 3-210-219 & $6 / 22 / 2003$ & 19:35 & 11.344 & 0.049 \\
\hline $3-210-221$ & $6 / 22 / 2003$ & $21: 42$ & 11.432 & 0.048 \\
\hline $3-210-223$ & $6 / 23 / 2003$ & $6: 20$ & 11.792 & 0.045 \\
\hline 3-210-225 & $6 / 23 / 2003$ & 9:08 & 11.908 & 0.044 \\
\hline $3-210-227$ & $6 / 23 / 2003$ & $11: 52$ & 12.022 & 0.042 \\
\hline $3-210-229$ & $6 / 23 / 2003$ & $17: 24$ & 12.253 & 0.042 \\
\hline $3-210-231$ & $6 / 23 / 2003$ & $20: 35$ & 12.385 & 0.041 \\
\hline $3-210-233$ & $6 / 24 / 2003$ & $6: 29$ & 12.798 & 0.037 \\
\hline $3-210-235$ & $6 / 24 / 2003$ & $15: 18$ & 13.165 & 0.036 \\
\hline 3-210-237 & $6 / 25 / 2003$ & $6: 37$ & 13.803 & 0.032 \\
\hline 3-210-239 & $6 / 25 / 2003$ & $15: 50$ & 14.188 & 0.030 \\
\hline $3-210-241$ & $6 / 26 / 2003$ & $6: 34$ & 14.801 & 0.027 \\
\hline $3-210-243$ & $6 / 26 / 2003$ & $14: 54$ & 15.149 & 0.026 \\
\hline
\end{tabular}

Table A-5: HPLC data from test 1, well 211

\begin{tabular}{|c|c|c|c|c|}
\hline Sample Name & Date & Time & $\begin{array}{c}\text { Time elapsed } \\
\text { (days) }\end{array}$ & $\begin{array}{c}\mathbf{2 , 4 , 5 - T F B A} \\
\text { (mg/L) }\end{array}$ \\
\hline $3-211-001$ & $6 / 10 / 2003$ & $17: 30$ & -0.74 & $<0.008$ \\
\hline $3-211-003$ & $6 / 11 / 2003$ & $12: 02$ & 0.03 & $<0.008$ \\
\hline $3-211-005$ & $6 / 11 / 2003$ & $12: 59$ & 0.07 & $<0.008$ \\
\hline $3-211-008$ & $6 / 11 / 2003$ & $15: 05$ & 0.16 & $<0.008$ \\
\hline $3-211-009$ & $6 / 11 / 2003$ & $16: 22$ & 0.21 & $<0.008$ \\
\hline $3-211-011$ & $6 / 11 / 2003$ & $18: 05$ & 0.28 & $<0.008$ \\
\hline $3-211-014$ & $6 / 11 / 2003$ & $19: 58$ & 0.36 & $<0.008$ \\
\hline $3-211-015$ & $6 / 11 / 2003$ & $22: 02$ & 0.45 & $<0.008$ \\
\hline
\end{tabular}


Table A-5: Continued

\begin{tabular}{|c|c|c|c|c|}
\hline Sample Name & Date & Time & $\begin{array}{c}\text { Time elapsed } \\
\text { (days) }\end{array}$ & $\begin{array}{c}2,4,5-T F B A \\
(\mathrm{mg} / \mathrm{L})\end{array}$ \\
\hline 3-211-018 & $6 / 11 / 2003$ & 23:40 & 0.51 & $<0.008$ \\
\hline 3-211-019 & $6 / 12 / 2003$ & 4:32 & 0.72 & $<0.008$ \\
\hline 3-211-021 & $6 / 12 / 2003$ & $6: 07$ & 0.78 & $<0.008$ \\
\hline 3-211-023 & $6 / 12 / 2003$ & $8: 21$ & 0.88 & $<0.008$ \\
\hline 3-211-025 & $6 / 12 / 2003$ & $10: 07$ & 0.95 & $<0.008$ \\
\hline 3-211-027 & $6 / 12 / 2003$ & $12: 47$ & 1.06 & $<0.008$ \\
\hline 3-211-029 & $6 / 12 / 2003$ & $14: 07$ & 1.12 & $<0.008$ \\
\hline 3-211-031 & $6 / 12 / 2003$ & $16: 00$ & 1.19 & $<0.008$ \\
\hline 3-211-033 & $6 / 12 / 2003$ & $18: 00$ & 1.28 & $<0.008$ \\
\hline 3-211-035 & $6 / 12 / 2003$ & 20:07 & 1.37 & $<0.008$ \\
\hline 3-211-039 & $6 / 12 / 2003$ & 22:05 & 1.45 & $<0.008$ \\
\hline 3-211-041 & $6 / 13 / 2003$ & $4: 20$ & 1.71 & $<0.008$ \\
\hline 3-211-047 & $6 / 13 / 2003$ & $6: 33$ & 1.80 & $<0.008$ \\
\hline 3-211-049 & $6 / 13 / 2003$ & $8: 38$ & 1.89 & $<0.008$ \\
\hline 3-211-051 & $6 / 13 / 2003$ & $10: 44$ & 1.98 & $<0.008$ \\
\hline 3-211-052 & $6 / 13 / 2003$ & $12: 46$ & 2.06 & $<0.008$ \\
\hline 3-211-053 & $6 / 13 / 2003$ & $12: 46$ & 2.06 & $<0.008$ \\
\hline 3-211-055 & $6 / 13 / 2003$ & $14: 35$ & 2.14 & $<0.008$ \\
\hline 3-211-057 & $6 / 13 / 2003$ & 16:04 & 2.20 & $<0.008$ \\
\hline 3-211-059 & $6 / 13 / 2003$ & 18:00 & 2.28 & $<0.008$ \\
\hline 3-211-061 & $6 / 13 / 2003$ & 20:00 & 2.36 & $<0.008$ \\
\hline 3-211-063 & 6/13/2003 & 22:03 & 2.45 & $<0.008$ \\
\hline 3-211-065 & $6 / 13 / 2003$ & $23: 23$ & 2.50 & $<0.008$ \\
\hline 3-211-067 & $6 / 14 / 2003$ & $4: 21$ & 2.71 & 0.006 \\
\hline 3-211-073 & $6 / 14 / 2003$ & $10: 41$ & 2.97 & 0.018 \\
\hline 3-211-079 & $6 / 14 / 2003$ & $16: 00$ & 3.19 & 0.033 \\
\hline 3-211-085 & $6 / 14 / 2003$ & $21: 52$ & 3.44 & 0.033 \\
\hline 3-211-091 & $6 / 15 / 2003$ & $6: 42$ & 3.81 & 0.083 \\
\hline 3-211-096 & $6 / 15 / 2003$ & $12: 30$ & 4.05 & 0.098 \\
\hline 3-211-109 & $6 / 15 / 2003$ & 23:08 & 4.49 & 0.109 \\
\hline 3-211-119 & $6 / 16 / 2003$ & $12: 09$ & 5.03 & 0.146 \\
\hline 3-211-131 & $6 / 16 / 2003$ & 23:37 & 5.51 & 0.165 \\
\hline 3-211-155 & $6 / 18 / 2003$ & $6: 07$ & 6.78 & 0.207 \\
\hline 3-211-161 & $6 / 18 / 2003$ & $14: 48$ & 7.14 & 0.224 \\
\hline 3-211-169 & $6 / 19 / 2003$ & $5: 40$ & 7.76 & 0.233 \\
\hline 3-211-175 & $6 / 19 / 2003$ & $16: 57$ & 8.23 & 0.229 \\
\hline $3-211-187$ & 6/20/2003 & $12: 03$ & 9.03 & 0.216 \\
\hline 3-211-193 & $6 / 20 / 2003$ & $21: 50$ & 9.44 & 0.209 \\
\hline 3-211-199 & $6 / 21 / 2003$ & $11: 59$ & 10.03 & 0.199 \\
\hline 3-211-205 & $6 / 21 / 2003$ & $21: 48$ & 10.44 & 0.194 \\
\hline $3-211-213$ & $6 / 22 / 2003$ & $11: 58$ & 11.03 & 0.181 \\
\hline 3-211-219 & $6 / 22 / 2003$ & 21:36 & 11.43 & 0.173 \\
\hline 3-211-225 & $6 / 23 / 2003$ & $12: 01$ & 12.03 & 0.159 \\
\hline
\end{tabular}


Table A-5: Continued

\begin{tabular}{|c|c|c|c|c|}
\hline Sample Name & Date & Time & $\begin{array}{c}\text { Time elapsed } \\
\text { (days) }\end{array}$ & $\begin{array}{c}\mathbf{2 , 4 , 5 - T F B A} \\
\text { (mg/L) }\end{array}$ \\
\hline $3-211-231$ & $6 / 24 / 2003$ & $6: 40$ & 12.81 & 0.147 \\
\hline $3-211-237$ & $6 / 25 / 2003$ & $16: 02$ & 14.20 & 0.117 \\
\hline $3-211-243$ & $6 / 30 / 2003$ & $15: 02$ & 19.15 & 0.073 \\
\hline
\end{tabular}

Table A-6: HPLC data from test 1, well 212

\begin{tabular}{|c|c|c|c|c|}
\hline Sample Name & Date & Time & $\begin{array}{c}\text { Time elapsed } \\
\text { (days) }\end{array}$ & $\begin{array}{c}2,4,5-\mathrm{TFBA} \\
(\mathrm{mg} / \mathrm{L})\end{array}$ \\
\hline 3-212-001 & $6 / 10 / 2003$ & 19:31 & -0.66 & $<0.008$ \\
\hline $3-212-003$ & $6 / 11 / 2003$ & $17: 21$ & 0.25 & $<0.008$ \\
\hline 3-212-006 & $6 / 11 / 2003$ & $21: 50$ & 0.44 & $<0.008$ \\
\hline 3-212-007 & $6 / 12 / 2003$ & $9: 43$ & 0.93 & $<0.008$ \\
\hline 3-212-009 & $6 / 12 / 2003$ & $13: 43$ & 1.10 & $<0.008$ \\
\hline 3-212-011 & $6 / 12 / 2003$ & 19:03 & 1.32 & $<0.008$ \\
\hline $3-212-013$ & $6 / 12 / 2003$ & $21: 50$ & 1.44 & $<0.008$ \\
\hline 3-212-015 & $6 / 13 / 2003$ & 7:09 & 1.83 & $<0.008$ \\
\hline 3-212-017 & $6 / 13 / 2003$ & $12: 31$ & 2.05 & $<0.008$ \\
\hline 3-212-018 & $6 / 13 / 2003$ & $12: 31$ & 2.05 & $<0.008$ \\
\hline 3-212-019 & $6 / 13 / 2003$ & $15: 54$ & 2.19 & $<0.008$ \\
\hline $3-212-021$ & $6 / 13 / 2003$ & $19: 50$ & 2.35 & $<0.008$ \\
\hline 3-212-023 & $6 / 14 / 2003$ & $7: 11$ & 2.83 & $<0.008$ \\
\hline 3-212-025 & $6 / 14 / 2003$ & $16: 33$ & 3.22 & $<0.008$ \\
\hline 3-212-027 & $6 / 14 / 2003$ & $20: 40$ & 3.39 & $<0.008$ \\
\hline 3-212-029 & $6 / 15 / 2003$ & $7: 12$ & 3.83 & $<0.008$ \\
\hline 3-212-032 & $6 / 15 / 2003$ & $15: 47$ & 4.19 & $<0.008$ \\
\hline 3-212-037 & $6 / 16 / 2003$ & $9: 56$ & 4.94 & $<0.008$ \\
\hline 3-212-039 & $6 / 16 / 2003$ & $17: 05$ & 5.24 & $<0.008$ \\
\hline 3-212-041 & $6 / 16 / 2003$ & $20: 25$ & 5.38 & $<0.008$ \\
\hline 3-212-043 & $6 / 17 / 2003$ & $6: 00$ & 5.78 & $<0.008$ \\
\hline 3-212-045 & $6 / 17 / 2003$ & $10: 15$ & 5.95 & $<0.008$ \\
\hline 3-212-047 & $6 / 17 / 2003$ & $18: 50$ & 6.31 & $<0.008$ \\
\hline 3-212-049 & $6 / 17 / 2003$ & $22: 00$ & 6.44 & $<0.008$ \\
\hline 3-212-051 & $6 / 18 / 2003$ & $5: 53$ & 6.77 & $<0.008$ \\
\hline 3-212-053 & $6 / 18 / 2003$ & $10: 56$ & 6.98 & $<0.008$ \\
\hline 3-212-056 & $6 / 18 / 2003$ & $16: 57$ & 7.23 & $<0.008$ \\
\hline 3-212-057 & $6 / 19 / 2003$ & $7: 38$ & 7.85 & $<0.008$ \\
\hline 3-212-059 & $6 / 19 / 2003$ & $11: 45$ & 8.02 & $<0.008$ \\
\hline 3-212-061 & $6 / 19 / 2003$ & $18: 15$ & 8.29 & $<0.008$ \\
\hline $3-212-063$ & $6 / 20 / 2003$ & $7: 48$ & 8.85 & $<0.008$ \\
\hline 3-212-065 & $6 / 20 / 2003$ & $18: 10$ & 9.28 & $<0.008$ \\
\hline 3-212-067 & $6 / 21 / 2003$ & $7: 29$ & 9.84 & $<0.008$ \\
\hline 3-212-069 & $6 / 21 / 2003$ & $18: 10$ & 10.28 & $<0.008$ \\
\hline $3-212-071$ & $6 / 22 / 2003$ & 8:04 & 10.86 & $<0.008$ \\
\hline
\end{tabular}


Table A-6: Continued

\begin{tabular}{|c|c|c|c|c|}
\hline Sample Name & Date & Time & $\begin{array}{c}\text { Time elapsed } \\
\text { (days) }\end{array}$ & $\begin{array}{c}\mathbf{2 , 4 , 5 - T F B A} \\
\text { (mg/L) }\end{array}$ \\
\hline $3-212-073$ & $6 / 22 / 2003$ & $18: 04$ & 11.28 & $<0.008$ \\
\hline $3-212-075$ & $6 / 23 / 2003$ & $7: 54$ & 11.86 & $<0.008$ \\
\hline $3-212-079$ & $6 / 24 / 2003$ & $7: 49$ & 12.85 & $<0.008$ \\
\hline $3-212-081$ & $6 / 24 / 2003$ & $16: 33$ & 13.22 & $<0.008$ \\
\hline $3-212-083$ & $6 / 25 / 2003$ & $8: 12$ & 13.87 & $<0.008$ \\
\hline $3-212-085$ & $6 / 25 / 2003$ & $17: 12$ & 14.24 & $<0.008$ \\
\hline $3-212-087$ & $6 / 30 / 2003$ & $16: 17$ & 19.21 & $<0.008$ \\
\hline $3-212-089$ & $7 / 3 / 2003$ & $10: 54$ & 21.98 & $<0.008$ \\
\hline $3-212-091$ & $6 / 26 / 2003$ & $8: 00$ & 14.86 & $<0.008$ \\
\hline $3-212-093$ & $7 / 8 / 2003$ & $11: 25$ & 27.00 & $<0.008$ \\
\hline $3-212-095$ & $7 / 10 / 2003$ & $14: 20$ & 29.13 & 0.005 \\
\hline $3-212-097$ & $7 / 17 / 2003$ & $14: 07$ & 36.12 & 0.005 \\
\hline $3-212-099$ & $7 / 24 / 2003$ & $10: 14$ & 42.95 & 0.003 \\
\hline $3-212-105$ & $6 / 15 / 2003$ & $21: 08$ & 4.41 & $<0.008$ \\
\hline
\end{tabular}

Table A-7: HPLC data from test 1, lysimeter 198114

\begin{tabular}{|c|c|c|c|c|}
\hline Sample Name & Date & Time & $\begin{array}{c}\text { Time elapsed } \\
\text { (days) }\end{array}$ & $\begin{array}{c}2,4,5-\text { TFBA } \\
(\mathrm{mg} / \mathrm{L})\end{array}$ \\
\hline 3-198114-003 & $6 / 11 / 2003$ & $16: 00$ & 0.19 & $<0.008$ \\
\hline 3-198114-009 & $6 / 11 / 2003$ & $22: 55$ & 0.48 & $<0.008$ \\
\hline 3-198114-011 & $6 / 12 / 2003$ & $6: 42$ & 0.81 & $<0.008$ \\
\hline 3-198114-013 & $6 / 12 / 2003$ & $14: 49$ & 1.15 & $<0.008$ \\
\hline 3-198114-015 & $6 / 12 / 2003$ & $19: 16$ & 1.33 & $<0.008$ \\
\hline 3-198114-019 & $6 / 13 / 2003$ & $5: 20$ & 1.75 & $<0.008$ \\
\hline 3-198114-021 & $6 / 13 / 2003$ & $9: 47$ & 1.94 & $<0.008$ \\
\hline 3-198114-023 & $6 / 13 / 2003$ & $22: 24$ & 2.46 & $<0.008$ \\
\hline 3-198114-025 & $6 / 13 / 2003$ & $18: 52$ & 2.31 & $<0.008$ \\
\hline 3-198114-027 & $6 / 14 / 2003$ & $5: 41$ & 2.76 & 0.010 \\
\hline 3-198114-029 & $6 / 14 / 2003$ & $9: 30$ & 2.92 & 0.004 \\
\hline 3-198114-030 & $6 / 14 / 2003$ & $14: 51$ & 3.15 & $<0.008$ \\
\hline 3-198114-031 & $6 / 14 / 2003$ & 19:05 & 3.32 & $<0.008$ \\
\hline 3-198114-033 & $6 / 14 / 2003$ & $22: 45$ & 3.48 & $<0.008$ \\
\hline 3-198114-035 & $6 / 15 / 2003$ & $5: 40$ & 3.76 & $<0.008$ \\
\hline 3-198114-037 & $6 / 15 / 2003$ & $5: 40$ & 3.76 & $<0.008$ \\
\hline 3-198114-039 & $6 / 15 / 2003$ & $9: 48$ & 3.94 & $<0.008$ \\
\hline 3-198114-040 & $6 / 15 / 2003$ & $9: 48$ & 3.94 & $<0.008$ \\
\hline 3-198114-041 & $6 / 15 / 2003$ & $14: 59$ & 4.15 & $<0.008$ \\
\hline 3-198114-043 & $6 / 15 / 2003$ & $19: 47$ & 4.35 & $<0.008$ \\
\hline 3-198114-046 & $6 / 15 / 2003$ & $22: 26$ & 4.46 & $<0.008$ \\
\hline 3-198114-049 & $6 / 16 / 2003$ & $15: 16$ & 5.16 & $<0.008$ \\
\hline 3-198114-053 & $6 / 16 / 2003$ & $18: 45$ & 5.31 & $<0.008$ \\
\hline 3-198114-055 & $6 / 16 / 2003$ & $22: 30$ & 5.47 & $<0.008$ \\
\hline
\end{tabular}


Table A-7: Continued

\begin{tabular}{|c|c|c|c|c|}
\hline Sample Name & Date & Time & $\begin{array}{c}\text { Time elapsed } \\
\text { (days) }\end{array}$ & $\begin{array}{c}2,4,5-T F B A \\
(\mathrm{mg} / \mathrm{L})\end{array}$ \\
\hline 3-198114-057 & $6 / 16 / 2003$ & 7:08 & 4.83 & $<0.008$ \\
\hline 3-198114-058 & $6 / 17 / 2003$ & $13: 21$ & 6.08 & $<0.008$ \\
\hline 3-198114-059 & $6 / 17 / 2003$ & $13: 21$ & 6.08 & $<0.008$ \\
\hline 3-198114-061 & $6 / 17 / 2003$ & $17: 40$ & 6.26 & $<0.008$ \\
\hline 3-198114-063 & $6 / 17 / 2003$ & $20: 55$ & 6.40 & $<0.008$ \\
\hline 3-198114-065 & $6 / 18 / 2003$ & $6: 37$ & 6.80 & $<0.008$ \\
\hline 3-198114-066 & $6 / 18 / 2003$ & $15: 20$ & 7.17 & $<0.008$ \\
\hline 3-198114-069 & $6 / 18 / 2003$ & $21: 42$ & 7.43 & $<0.008$ \\
\hline 3-198114-071 & $6 / 19 / 2003$ & $6: 14$ & 7.79 & $<0.008$ \\
\hline 3-198114-073 & $6 / 19 / 2003$ & $17: 13$ & 8.25 & $<0.008$ \\
\hline 3-198114-075 & $6 / 19 / 2003$ & $22: 00$ & 8.44 & $<0.008$ \\
\hline 3-198114-077 & $6 / 20 / 2003$ & $6: 15$ & 8.79 & 0.007 \\
\hline 3-198114-078 & $6 / 20 / 2003$ & $11: 14$ & 9.00 & $<0.008$ \\
\hline 3-198114-079 & $6 / 20 / 2003$ & $17: 07$ & 9.24 & $<0.008$ \\
\hline 3-198114-081 & $6 / 20 / 2003$ & $21: 06$ & 9.41 & $<0.008$ \\
\hline 3-198114-085 & $6 / 21 / 2003$ & $10: 46$ & 9.98 & $<0.008$ \\
\hline 3-198114-089 & $6 / 21 / 2003$ & $21: 03$ & 10.40 & $<0.008$ \\
\hline 3-198114-091 & $6 / 22 / 2003$ & $6: 47$ & 10.81 & $<0.008$ \\
\hline 3-198114-093 & $6 / 22 / 2003$ & $10: 42$ & 10.97 & $<0.008$ \\
\hline 3-198114-095 & $6 / 22 / 2003$ & $17: 02$ & 11.24 & $<0.008$ \\
\hline 3-198114-097 & $6 / 22 / 2003$ & $20: 54$ & 11.40 & $<0.008$ \\
\hline 3-198114-099 & $6 / 23 / 2003$ & $6: 52$ & 11.81 & $<0.008$ \\
\hline $3-198114-101$ & $6 / 23 / 2003$ & $17: 41$ & 12.26 & $<0.008$ \\
\hline 3-198114-103 & $6 / 23 / 2003$ & $20: 53$ & 12.40 & $<0.008$ \\
\hline 3-198114-105 & $6 / 24 / 2003$ & $6: 45$ & 12.81 & $<0.008$ \\
\hline 3-198114-108 & $6 / 25 / 2003$ & $15: 50$ & 14.19 & $<0.008$ \\
\hline 3-198114-109 & $6 / 26 / 2003$ & $15: 50$ & 15.19 & $<0.008$ \\
\hline 3-198114-110 & $6 / 26 / 2003$ & $14: 50$ & 15.15 & $<0.008$ \\
\hline 3-198114-113 & $6 / 30 / 2003$ & $15: 15$ & 19.16 & $<0.008$ \\
\hline Tst2-198114-003 & $8 / 17 / 2003$ & $6: 37$ & 66.80 & $<0.024$ \\
\hline Tst2-198114-121 & $8 / 17 / 2003$ & $11: 03$ & 66.99 & 0.020 \\
\hline Tst2-198114-122 & $8 / 17 / 2003$ & $20: 08$ & 67.37 & 0.021 \\
\hline Tst2-198114-123 & $8 / 18 / 2003$ & $9: 30$ & 67.92 & 0.020 \\
\hline Tst2-198114-124 & $8 / 18 / 2003$ & $12: 50$ & 68.06 & 0.018 \\
\hline Tst2-198114-125 & $8 / 18 / 2003$ & 19:31 & 68.34 & 0.018 \\
\hline Tst2-198114-126 & $8 / 19 / 2003$ & $8: 20$ & 68.88 & 0.020 \\
\hline Tst2-198114-127 & $8 / 20 / 2003$ & $9: 37$ & 69.93 & 0.021 \\
\hline Tst2-198114-129 & $8 / 26 / 2003$ & $9: 25$ & 75.92 & 0.024 \\
\hline Tst2-198114-145 & $8 / 27 / 2003$ & $8: 45$ & 76.89 & 0.029 \\
\hline
\end{tabular}


Table A-8: HPLC data from test 1, lysimeter 198126

\begin{tabular}{|c|c|c|c|c|}
\hline Sample Name & Date & Time & $\begin{array}{l}\text { Time elapsed } \\
\text { (days) }\end{array}$ & $\begin{array}{c}\text { 2,4,5-TFBA } \\
\text { (mg/L) }\end{array}$ \\
\hline 3-198126-002 & $6 / 10 / 2003$ & $18: 36$ & -0.70 & $<0.008$ \\
\hline 3-198126-005 & $6 / 11 / 2003$ & $16: 05$ & 0.20 & $<0.008$ \\
\hline 3-198126-008 & $6 / 11 / 2003$ & $19: 13$ & 0.33 & $<0.008$ \\
\hline 3-198126-010 & $6 / 11 / 2003$ & $22: 58$ & 0.48 & $<0.008$ \\
\hline 3-198126-011 & $6 / 11 / 2003$ & $22: 58$ & 0.48 & $<0.008$ \\
\hline 3-198126-013 & $6 / 12 / 2003$ & $6: 50$ & 0.81 & $<0.008$ \\
\hline 3-198126-015 & $6 / 12 / 2003$ & $14: 54$ & 1.15 & $<0.008$ \\
\hline 3-198126-017 & $6 / 12 / 2003$ & $19: 18$ & 1.33 & $<0.008$ \\
\hline 3-198126-019 & $6 / 12 / 2003$ & $22: 47$ & 1.48 & $<0.008$ \\
\hline 3-198126-020 & $6 / 12 / 2003$ & $22: 17$ & 1.46 & $<0.008$ \\
\hline 3-198126-023 & $6 / 13 / 2003$ & $5: 25$ & 1.75 & $<0.008$ \\
\hline 3-198126-025 & $6 / 13 / 2003$ & 9:40 & 1.93 & $<0.008$ \\
\hline 3-198126-028 & $6 / 13 / 2003$ & $14: 57$ & 2.15 & $<0.008$ \\
\hline 3-198126-031 & $6 / 13 / 2003$ & $18: 55$ & 2.32 & $<0.008$ \\
\hline 3-198126-033 & $6 / 13 / 2003$ & $18: 55$ & 2.32 & $<0.008$ \\
\hline 3-198126-035 & $6 / 13 / 2003$ & $22: 26$ & 2.46 & $<0.008$ \\
\hline 3-198126-036 & $6 / 13 / 2003$ & $22: 26$ & 2.46 & $<0.008$ \\
\hline 3-198126-037 & $6 / 14 / 2003$ & $5: 36$ & 2.76 & $<0.008$ \\
\hline 3-198126-041 & $6 / 14 / 2003$ & 9:26 & 2.92 & $<0.008$ \\
\hline 3-198126-043 & $6 / 14 / 2003$ & $14: 55$ & 3.15 & $<0.008$ \\
\hline 3-198126-044 & $6 / 14 / 2003$ & $14: 55$ & 3.15 & $<0.008$ \\
\hline 3-198126-045 & $6 / 14 / 2003$ & $19: 10$ & 3.33 & $<0.008$ \\
\hline 3-198126-047 & $6 / 14 / 2003$ & $19: 10$ & 3.33 & $<0.008$ \\
\hline 3-198126-050 & $6 / 14 / 2003$ & $22: 47$ & 3.48 & $<0.008$ \\
\hline 3-198126-051 & $6 / 15 / 2003$ & $5: 34$ & 3.76 & $<0.008$ \\
\hline 3-198126-055 & $6 / 15 / 2003$ & $9: 41$ & 3.93 & $<0.008$ \\
\hline 3-198126-057 & $6 / 15 / 2003$ & 15:02 & 4.15 & $<0.008$ \\
\hline 3-198126-059 & $6 / 15 / 2003$ & $15: 02$ & 4.15 & $<0.008$ \\
\hline 3-198126-061 & $6 / 15 / 2003$ & $19: 49$ & 4.35 & $<0.008$ \\
\hline 3-198126-062 & $6 / 15 / 2003$ & $19: 49$ & 4.35 & $<0.008$ \\
\hline 3-198126-065 & $6 / 15 / 2003$ & $22: 28$ & 4.46 & $<0.008$ \\
\hline 3-198126-066 & $6 / 16 / 2003$ & $8: 58$ & 4.90 & $<0.008$ \\
\hline 3-198126-067 & $6 / 16 / 2003$ & $8: 58$ & 4.90 & $<0.008$ \\
\hline 3-198126-069 & $6 / 16 / 2003$ & $15: 24$ & 5.17 & $<0.008$ \\
\hline 3-198126-073 & $6 / 16 / 2003$ & $18: 50$ & 5.31 & $<0.008$ \\
\hline 3-198126-074 & $6 / 16 / 2003$ & $18: 45$ & 5.31 & $<0.008$ \\
\hline 3-198126-081 & $6 / 17 / 2003$ & 13:03 & 6.07 & $<0.008$ \\
\hline 3-198126-082 & $6 / 17 / 2003$ & 13:03 & 6.07 & $<0.008$ \\
\hline 3-198126-083 & $6 / 17 / 2003$ & $17: 45$ & 6.27 & $<0.008$ \\
\hline 3-198126-085 & $6 / 17 / 2003$ & $17: 45$ & 6.27 & $<0.008$ \\
\hline 3-198126-087 & $6 / 17 / 2003$ & $21: 00$ & 6.40 & $<0.008$ \\
\hline 3-198126-090 & $6 / 18 / 2003$ & $6: 44$ & 6.81 & $<0.008$ \\
\hline 3-198126-093 & $6 / 18 / 2003$ & $17: 18$ & 7.25 & $<0.008$ \\
\hline
\end{tabular}


Table A-8: Continued

\begin{tabular}{|c|c|c|c|c|}
\hline Sample Name & Date & Time & $\begin{array}{c}\text { Time elapsed } \\
\text { (days) }\end{array}$ & $\begin{array}{c}2,4,5-\mathrm{TFBA} \\
(\mathrm{mg} / \mathrm{L})\end{array}$ \\
\hline 3-198126-095 & $6 / 18 / 2003$ & $21: 45$ & 7.43 & $<0.008$ \\
\hline 3-198126-099 & $6 / 19 / 2003$ & $6: 23$ & 7.79 & $<0.008$ \\
\hline 3-198126-101 & $6 / 19 / 2003$ & $17: 15$ & 8.25 & $<0.008$ \\
\hline 3-198126-105 & $6 / 19 / 2003$ & $22: 00$ & 8.44 & $<0.008$ \\
\hline 3-198126-107 & $6 / 20 / 2003$ & $6: 10$ & 8.78 & $<0.008$ \\
\hline 3-198126-109 & $6 / 20 / 2003$ & $11: 08$ & 8.99 & $<0.008$ \\
\hline 3-198126-113 & $6 / 20 / 2003$ & $17: 10$ & 9.24 & $<0.008$ \\
\hline 3-198126-115 & $6 / 20 / 2003$ & 21:09 & 9.41 & $<0.008$ \\
\hline 3-198126-117 & $6 / 20 / 2003$ & 21:09 & 9.41 & $<0.008$ \\
\hline 3-198126-153 & $6 / 21 / 2003$ & $10: 40$ & 9.97 & 0.005 \\
\hline 3-198126-155 & $6 / 21 / 2003$ & $17: 05$ & 10.24 & 0.006 \\
\hline 3-198126-157 & $6 / 21 / 2003$ & $17: 05$ & 10.24 & 0.005 \\
\hline 3-198126-159 & $6 / 21 / 2003$ & 21:05 & 10.41 & 0.003 \\
\hline 3-198126-161 & $6 / 21 / 2003$ & 21:05 & 10.41 & 0.006 \\
\hline 3-198126-163 & $6 / 22 / 2003$ & $6: 42$ & 10.81 & 0.007 \\
\hline 3-198126-165 & $6 / 22 / 2003$ & $10: 37$ & 10.97 & 0.010 \\
\hline 3-198126-169 & $6 / 22 / 2003$ & $17: 04$ & 11.24 & 0.008 \\
\hline 3-198126-171 & $6 / 22 / 2003$ & $20: 56$ & 11.40 & 0.011 \\
\hline 3-198126-175 & $6 / 23 / 2003$ & $6: 48$ & 11.81 & 0.013 \\
\hline 3-198126-179 & $6 / 23 / 2003$ & $17: 42$ & 12.27 & 0.016 \\
\hline 3-198126-185 & $6 / 24 / 2003$ & $6: 50$ & 12.81 & 0.017 \\
\hline 3-198126-187 & $6 / 24 / 2003$ & $16: 24$ & 13.21 & 0.015 \\
\hline 3-198126-189 & $6 / 25 / 2003$ & $16: 00$ & 14.19 & 0.025 \\
\hline 3-198126-191 & $6 / 26 / 2003$ & $15: 00$ & 15.15 & 0.030 \\
\hline 3-198126-193 & $6 / 30 / 2003$ & $15: 17$ & 19.16 & 0.040 \\
\hline Tst2-198126-003 & $8 / 1 / 2003$ & $11: 02$ & 50.99 & 0.064 \\
\hline Tst2-198126-016 & $8 / 2 / 2003$ & $20: 38$ & 52.39 & 0.045 \\
\hline Tst2-198126-133 & $8 / 17 / 2003$ & $6: 43$ & 66.81 & 0.023 \\
\hline Tst2-198126-134 & $8 / 17 / 2003$ & $11: 05$ & 66.99 & 0.021 \\
\hline Tst2-198126-135 & $8 / 17 / 2003$ & 20:05 & 67.36 & 0.021 \\
\hline Tst2-198126-136 & $8 / 18 / 2003$ & $5: 35$ & 67.76 & 0.020 \\
\hline Tst2-198126-137 & $8 / 18 / 2003$ & $12: 50$ & 68.06 & 0.019 \\
\hline Tst2-198126-138 & $8 / 18 / 2003$ & 19:31 & 68.34 & 0.019 \\
\hline Tst2-198126-139 & $8 / 19 / 2003$ & $8: 25$ & 68.88 & 0.018 \\
\hline Tst2-198126-140 & $8 / 19 / 2003$ & $14: 45$ & 69.14 & $<0.024$ \\
\hline Tst2-198126-141 & $8 / 19 / 2003$ & $20: 06$ & 69.37 & 0.016 \\
\hline Tst2-198126-142 & $8 / 20 / 2003$ & 9:45 & 69.93 & 0.014 \\
\hline Tst2-198126-158 & $8 / 26 / 2003$ & $9: 27$ & 75.92 & 0.007 \\
\hline Tst2-198126-159 & $8 / 27 / 2003$ & $8: 47$ & 76.89 & 0.006 \\
\hline
\end{tabular}


Table A-9: HPLC data from test 1, lysimeter 204129

\begin{tabular}{|c|c|c|c|c|}
\hline Sample Name & Date & Time & $\begin{array}{l}\text { Time elapsed } \\
\text { (days) }\end{array}$ & $\begin{array}{c}2,4,5-\mathrm{TFBA} \\
\text { (mg/L) }\end{array}$ \\
\hline 3-204129-008 & $6 / 11 / 2003$ & $19: 45$ & 0.35 & 0.007 \\
\hline 3-204129-011 & $6 / 11 / 2003$ & $23: 27$ & 0.50 & $<0.008$ \\
\hline 3-204129-015 & $6 / 12 / 2003$ & $12: 15$ & 1.04 & 0.005 \\
\hline 3-204129-017 & $6 / 12 / 2003$ & $17: 05$ & 1.24 & $<0.008$ \\
\hline 3-204129-019 & $6 / 12 / 2003$ & $23: 22$ & 1.50 & 0.008 \\
\hline $3-204129-023$ & $6 / 13 / 2003$ & $6: 12$ & 1.79 & 0.007 \\
\hline 3-204129-025 & $6 / 13 / 2003$ & $10: 24$ & 1.96 & $<0.008$ \\
\hline 3-204129-027 & $6 / 13 / 2003$ & $15: 26$ & 2.17 & 0.008 \\
\hline 3-204129-029 & $6 / 13 / 2003$ & $19: 20$ & 2.33 & 0.005 \\
\hline 3-204129-031 & $6 / 13 / 2003$ & $22: 55$ & 2.48 & $<0.008$ \\
\hline 3-204129-033 & $6 / 14 / 2003$ & $6: 19$ & 2.79 & $<0.008$ \\
\hline 3-204129-035 & $6 / 14 / 2003$ & $10: 12$ & 2.95 & $<0.008$ \\
\hline 3-204129-037 & $6 / 14 / 2003$ & $15: 25$ & 3.17 & $<0.008$ \\
\hline 3-204129-039 & $6 / 14 / 2003$ & $19: 35$ & 3.34 & $<0.008$ \\
\hline 3-204129-043 & $6 / 15 / 2003$ & $6: 20$ & 3.79 & $<0.008$ \\
\hline 3-204129-045 & $6 / 15 / 2003$ & $10: 16$ & 3.96 & $<0.008$ \\
\hline 3-204129-047 & $6 / 15 / 2003$ & $15: 18$ & 4.17 & $<0.008$ \\
\hline 3-204129-050 & $6 / 15 / 2003$ & $20: 17$ & 4.37 & $<0.008$ \\
\hline 3-204129-052 & $6 / 15 / 2003$ & $22: 55$ & 4.48 & 0.006 \\
\hline 3-204129-054 & $6 / 16 / 2003$ & $8: 42$ & 4.89 & $<0.008$ \\
\hline 3-204129-057 & $6 / 16 / 2003$ & $16: 00$ & 5.19 & $<0.008$ \\
\hline 3-204129-059 & $6 / 16 / 2003$ & $19: 20$ & 5.33 & 0.007 \\
\hline 3-204129-061 & $6 / 16 / 2003$ & $23: 07$ & 5.49 & $<0.008$ \\
\hline 3-204129-065 & $6 / 17 / 2003$ & $6: 55$ & 5.82 & $<0.008$ \\
\hline 3-204129-066 & $6 / 17 / 2003$ & $14: 00$ & 6.11 & $<0.008$ \\
\hline 3-204129-069 & $6 / 17 / 2003$ & $18: 22$ & 6.29 & $<0.008$ \\
\hline 3-204129-071 & $6 / 17 / 2003$ & $21: 33$ & 6.43 & $<0.008$ \\
\hline 3-204129-073 & $6 / 18 / 2003$ & $6: 55$ & 6.82 & $<0.008$ \\
\hline 3-204129-075 & $6 / 18 / 2003$ & $16: 10$ & 7.20 & $<0.008$ \\
\hline 3-204129-077 & $6 / 18 / 2003$ & $22: 26$ & 7.46 & $<0.008$ \\
\hline 3-204129-079 & $6 / 19 / 2003$ & 7:05 & 7.82 & $<0.008$ \\
\hline 3-204129-081 & $6 / 19 / 2003$ & $17: 45$ & 8.27 & $<0.008$ \\
\hline 3-204129-083 & 6/19/2003 & $22: 30$ & 8.47 & $<0.008$ \\
\hline 3-204129-087 & $6 / 20 / 2003$ & $11: 44$ & 9.02 & $<0.008$ \\
\hline 3-204129-089 & $6 / 20 / 2003$ & $17: 38$ & 9.26 & $<0.008$ \\
\hline 3-204129-091 & $6 / 20 / 2003$ & $21: 34$ & 9.43 & $<0.008$ \\
\hline 3-204129-095 & $6 / 21 / 2003$ & $11: 22$ & 10.00 & $<0.008$ \\
\hline 3-204129-099 & $6 / 21 / 2003$ & $21: 36$ & 10.43 & $<0.008$ \\
\hline 3-204129-101 & $6 / 22 / 2003$ & $7: 18$ & 10.83 & $<0.008$ \\
\hline 3-204129-103 & $6 / 22 / 2003$ & $11: 20$ & 11.00 & $<0.008$ \\
\hline 3-204129-105 & $6 / 22 / 2003$ & $17: 35$ & 11.26 & $<0.008$ \\
\hline 3-204129-107 & $6 / 22 / 2003$ & $21: 24$ & 11.42 & $<0.008$ \\
\hline 3-204129-109 & $6 / 23 / 2003$ & $18: 13$ & 12.29 & $<0.008$ \\
\hline
\end{tabular}


Table A-9: Continued

\begin{tabular}{|c|c|c|c|c|}
\hline Sample Name & Date & Time & $\begin{array}{c}\text { Time elapsed } \\
\text { (days) }\end{array}$ & $\begin{array}{c}2,4,5-T F B A \\
(\mathrm{mg} / \mathrm{L})\end{array}$ \\
\hline 3-204129-111 & $6 / 23 / 2003$ & 21:21 & 12.42 & $<0.008$ \\
\hline 3-204129-119 & $6 / 26 / 2003$ & $15: 25$ & 15.17 & 0.008 \\
\hline 3-204129-121 & $6 / 30 / 2003$ & $15: 46$ & 19.18 & 0.025 \\
\hline Tst2-204129-005 & $8 / 1 / 2003$ & $12: 32$ & 51.05 & 0.056 \\
\hline Tst2-204129-009 & $8 / 1 / 2003$ & $18: 09$ & 51.28 & 0.047 \\
\hline Tst2-204129-011 & $8 / 2 / 2003$ & $5: 38$ & 51.76 & 0.052 \\
\hline Tst2-204129-013 & $8 / 2 / 2003$ & $11: 54$ & 52.02 & 0.039 \\
\hline Tst2-204129-017 & $8 / 2 / 2003$ & $20: 58$ & 52.40 & 0.043 \\
\hline Tst2-204129-019 & $8 / 3 / 2003$ & $5: 41$ & 52.76 & 0.048 \\
\hline Tst2-204129-021 & $8 / 3 / 2003$ & $12: 41$ & 53.06 & 0.036 \\
\hline Tst2-204129-025 & $8 / 3 / 2003$ & $20: 27$ & 53.38 & 0.047 \\
\hline Tst2-204129-027 & $8 / 4 / 2003$ & $6: 15$ & 53.79 & 0.049 \\
\hline Tst2-204129-033 & $8 / 4 / 2003$ & $20: 20$ & 54.38 & 0.052 \\
\hline Tst2-204129-037 & $8 / 5 / 2003$ & $6: 15$ & 54.79 & 0.047 \\
\hline Tst2-204129-039 & $8 / 5 / 2003$ & $10: 30$ & 54.97 & 0.042 \\
\hline Tst2-204129-041 & $8 / 5 / 2003$ & $21: 33$ & 55.43 & 0.030 \\
\hline Tst2-204129-047 & $8 / 6 / 2003$ & $6: 25$ & 55.80 & 0.042 \\
\hline Tst2-204129-050 & $8 / 6 / 2003$ & $13: 07$ & 56.07 & 0.034 \\
\hline Tst2-204129-051 & $8 / 6 / 2003$ & $20: 22$ & 56.38 & 0.043 \\
\hline Tst2-204129-053 & $8 / 7 / 2003$ & $5: 33$ & 56.76 & 0.044 \\
\hline Tst2-204129-055 & $8 / 7 / 2003$ & $18: 30$ & 57.30 & 0.047 \\
\hline Tst2-204129-059 & $8 / 8 / 2003$ & $7: 03$ & 57.82 & 0.041 \\
\hline Tst2-204129-061 & $8 / 8 / 2003$ & $10: 45$ & 57.98 & 0.042 \\
\hline Tst2-204129-065 & $8 / 9 / 2003$ & $6: 05$ & 58.78 & 0.040 \\
\hline Tst2-204129-066 & $8 / 8 / 2003$ & $17: 46$ & 58.27 & 0.040 \\
\hline Tst2-204129-069 & $8 / 9 / 2003$ & $11: 58$ & 59.03 & 0.034 \\
\hline Tst2-204129-073 & $8 / 9 / 2003$ & $20: 40$ & 59.39 & 0.041 \\
\hline Tst2-204129-075 & $8 / 10 / 2003$ & $5: 55$ & 59.77 & 0.039 \\
\hline Tst2-204129-079 & $8 / 10 / 2003$ & $12: 25$ & 60.05 & 0.034 \\
\hline Tst2-204129-081 & $8 / 10 / 2003$ & $19: 15$ & 60.33 & 0.038 \\
\hline Tst2-204129-087 & $8 / 11 / 2003$ & $9: 45$ & 60.93 & 0.033 \\
\hline Tst2-204129-089 & $8 / 11 / 2003$ & $20: 32$ & 61.38 & 0.032 \\
\hline Tst2-204129-093 & $8 / 12 / 2003$ & $6: 30$ & 61.80 & 0.030 \\
\hline Tst2-204129-096 & $8 / 12 / 2003$ & 13:05 & 62.07 & 0.033 \\
\hline Tst2-204129-099 & $8 / 13 / 2003$ & $6: 04$ & 62.78 & 0.034 \\
\hline Tst2-204129-101 & $8 / 13 / 2003$ & $11: 16$ & 63.00 & 0.032 \\
\hline Tst2-204129-105 & $8 / 13 / 2003$ & $20: 31$ & 63.38 & 0.033 \\
\hline Tst2-204129-109 & $8 / 14 / 2003$ & $6: 59$ & 63.82 & 0.032 \\
\hline Tst2-204129-111 & $8 / 14 / 2003$ & $20: 42$ & 64.39 & 0.034 \\
\hline Tst2-204129-113 & $8 / 15 / 2003$ & $8: 14$ & 64.87 & 0.033 \\
\hline Tst2-204129-117 & $8 / 15 / 2003$ & $19: 57$ & 65.36 & 0.031 \\
\hline Tst2-204129-119 & $8 / 16 / 2003$ & $8: 12$ & 65.87 & 0.035 \\
\hline Tst2-204129-125 & $8 / 16 / 2003$ & $20: 23$ & 66.38 & 0.029 \\
\hline
\end{tabular}


Table A-9: Continued

\begin{tabular}{|c|c|c|c|c|}
\hline Sample Name & Date & Time & $\begin{array}{c}\text { Time elapsed } \\
\text { (days) }\end{array}$ & $\begin{array}{c}2,4,5-T F B A \\
(\mathrm{mg} / \mathrm{L})\end{array}$ \\
\hline Tst2-204129-128 & $8 / 17 / 2003$ & $7: 00$ & 66.82 & 0.027 \\
\hline Tst2-204129-129 & $8 / 17 / 2003$ & $11: 23$ & 67.00 & 0.028 \\
\hline Tst2-204129-130 & $8 / 17 / 2003$ & $20: 26$ & 67.38 & 0.027 \\
\hline Tst2-204129-131 & $8 / 18 / 2003$ & $6: 25$ & 67.80 & 0.027 \\
\hline Tst2-204129-132 & $8 / 18 / 2003$ & $10: 00$ & 67.94 & 0.026 \\
\hline Tst2-204129-133 & $8 / 18 / 2003$ & 19:41 & 68.35 & 0.026 \\
\hline Tst2-204129-134 & $8 / 19 / 2003$ & $8: 55$ & 68.90 & 0.025 \\
\hline Tst2-204129-135 & $8 / 20 / 2003$ & $10: 05$ & 69.95 & 0.024 \\
\hline Tst2-204129-137 & $8 / 20 / 2003$ & $20: 50$ & 70.40 & 0.025 \\
\hline Tst2-204129-139 & $8 / 21 / 2003$ & $9: 22$ & 70.92 & 0.026 \\
\hline Tst2-204129-143 & $8 / 22 / 2003$ & 11:09 & 71.99 & 0.024 \\
\hline Tst2-204129-145 & $8 / 23 / 2003$ & $10: 37$ & 72.97 & 0.024 \\
\hline Tst2-204129-149 & $8 / 25 / 2003$ & $8: 41$ & 74.89 & 0.022 \\
\hline Tst2-204129-151 & $8 / 26 / 2003$ & $9: 45$ & 75.93 & 0.018 \\
\hline Tst2-204129-152 & $8 / 27 / 2003$ & 9:03 & 76.90 & 0.017 \\
\hline Tst2-204129-153 & $8 / 28 / 2003$ & $15: 50$ & 78.19 & 0.021 \\
\hline Tst2-204129-157 & $8 / 29 / 2003$ & $15: 25$ & 79.17 & 0.016 \\
\hline Tst2-204129-159 & $9 / 2 / 2003$ & $10: 20$ & 82.96 & 0.017 \\
\hline Tst2-204129-163 & $9 / 3 / 2003$ & $12: 35$ & 84.05 & 0.014 \\
\hline Tst2-204129-165 & $9 / 4 / 2003$ & $14: 20$ & 85.13 & 0.013 \\
\hline Tst2-204129-169 & $9 / 8 / 2003$ & $13: 50$ & 89.10 & 0.013 \\
\hline Tst2-204129-171 & $9 / 9 / 2003$ & $11: 25$ & 90.00 & 0.012 \\
\hline Tst2-204129-175 & $9 / 10 / 2003$ & $11: 23$ & 91.00 & 0.009 \\
\hline Tst2-204129-177 & $9 / 11 / 2003$ & $11: 30$ & 92.01 & 0.013 \\
\hline Tst2-204129-181 & $9 / 15 / 2003$ & $10: 59$ & 95.99 & 0.012 \\
\hline Tst2-204129-183 & 9/16/2003 & $8: 43$ & 96.89 & 0.012 \\
\hline Tst2-204129-187 & $9 / 18 / 2003$ & $10: 55$ & 98.98 & 0.012 \\
\hline Tst2-204129-189 & $9 / 22 / 2003$ & $15: 25$ & 103.17 & 0.009 \\
\hline Tst2-204129-193 & 9/25/2003 & $15: 05$ & 106.16 & 0.013 \\
\hline Tst2-204129-195 & $10 / 20 / 2003$ & $14: 50$ & 131.15 & 0.007 \\
\hline
\end{tabular}

Table A-10: HPLC data from test 2, well 197

\begin{tabular}{|c|c|c|c|c|}
\hline Sample Name & Date & Time & $\begin{array}{c}\text { Time elapsed } \\
\text { (days) }\end{array}$ & 2,4-DFBA (mg/L) \\
\hline Tst2-197-001 & $8 / 5 / 2003$ & $7: 55$ & 4.76 & $<0.016$ \\
\hline Tst2-197-005 & $8 / 5 / 2003$ & $9: 25$ & 4.82 & $<0.016$ \\
\hline Tst2-197-009 & $8 / 5 / 2003$ & $21: 12$ & 5.31 & $<0.016$ \\
\hline Tst2-197-013 & $8 / 6 / 2003$ & $8: 52$ & 5.80 & $<0.016$ \\
\hline Tst2-197-021 & $8 / 6 / 2003$ & $12: 16$ & 5.94 & $<0.016$ \\
\hline Tst2-197-025 & $8 / 6 / 2003$ & $19: 11$ & 6.23 & $<0.016$ \\
\hline Tst2-197-029 & $8 / 6 / 2003$ & $23: 28$ & 6.40 & $<0.016$ \\
\hline Tst2-197-031 & $8 / 7 / 2003$ & $5: 54$ & 6.67 & $<0.016$ \\
\hline
\end{tabular}


Table A-10: Continued

\begin{tabular}{|c|c|c|c|c|}
\hline Sample Name & Date & Time & $\begin{array}{c}\text { Time elapsed } \\
\text { (days) }\end{array}$ & 2,4-DFBA (mg/L) \\
\hline Tst2-197-035 & $8 / 7 / 2003$ & $12: 20$ & 6.94 & $<0.016$ \\
\hline Tst2-197-037 & 8/7/2003 & $18: 09$ & 7.18 & $<0.016$ \\
\hline Tst2-197-041 & $8 / 7 / 2003$ & $20: 29$ & 7.28 & $<0.016$ \\
\hline Tst2-197-043 & $8 / 7 / 2003$ & $22: 24$ & 7.36 & $<0.016$ \\
\hline Tst2-197-047 & $8 / 8 / 2003$ & $5: 46$ & 7.67 & $<0.016$ \\
\hline Tst2-197-049 & $8 / 8 / 2003$ & $8: 50$ & 7.80 & $<0.016$ \\
\hline Tst2-197-053 & $8 / 8 / 2003$ & $10: 34$ & 7.87 & $<0.016$ \\
\hline Tst2-197-057 & $8 / 8 / 2003$ & $17: 26$ & 8.15 & $<0.016$ \\
\hline Tst2-197-059 & $8 / 8 / 2003$ & $19: 48$ & 8.25 & $<0.016$ \\
\hline Tst2-197-061 & $8 / 8 / 2003$ & $22: 28$ & 8.36 & $<0.016$ \\
\hline Tst2-197-065 & $8 / 9 / 2003$ & $6: 47$ & 8.71 & $<0.016$ \\
\hline Tst2-197-067 & $8 / 9 / 2003$ & $9: 37$ & 8.83 & $<0.016$ \\
\hline Tst2-197-071 & $8 / 9 / 2003$ & $12: 08$ & 8.93 & $<0.016$ \\
\hline Tst2-197-073 & $8 / 9 / 2003$ & $18: 00$ & 9.18 & 0.003 \\
\hline Tst2-197-074 & $8 / 9 / 2003$ & $18: 10$ & 9.18 & $<0.016$ \\
\hline Tst2-197-077 & $8 / 9 / 2003$ & $20: 14$ & 9.27 & $<0.016$ \\
\hline Tst2-197-081 & 8/9/2003 & $22: 35$ & 9.37 & $<0.016$ \\
\hline Tst2-197-089 & $8 / 10 / 2003$ & $11: 38$ & 9.91 & $<0.016$ \\
\hline Tst2-197-091 & $8 / 10 / 2003$ & $18: 50$ & 10.21 & $<0.016$ \\
\hline Tst2-197-092 & $8 / 10 / 2003$ & $18: 50$ & 10.21 & $<0.016$ \\
\hline Tst2-197-094 & $8 / 10 / 2003$ & $22: 50$ & 10.38 & $<0.016$ \\
\hline Tst2-197-095 & $8 / 10 / 2003$ & $22: 50$ & 10.38 & $<0.016$ \\
\hline Tst2-197-097 & $8 / 11 / 2003$ & $9: 40$ & 10.83 & $<0.016$ \\
\hline Tst2-197-101 & $8 / 11 / 2003$ & $10: 30$ & 10.86 & 0.006 \\
\hline Tst2-197-103 & $8 / 11 / 2003$ & $14: 30$ & 11.03 & 0.008 \\
\hline Tst2-197-107 & $8 / 11 / 2003$ & $17: 57$ & 11.18 & 0.009 \\
\hline Tst2-197-111 & $8 / 11 / 2003$ & $20: 42$ & 11.29 & 0.011 \\
\hline Tst2-197-115 & $8 / 11 / 2003$ & $22: 54$ & 11.38 & 0.010 \\
\hline Tst2-197-117 & $8 / 12 / 2003$ & $5: 45$ & 11.67 & 0.008 \\
\hline Tst2-197-119 & $8 / 12 / 2003$ & $9: 25$ & 11.82 & 0.008 \\
\hline Tst2-197-123 & $8 / 12 / 2003$ & $15: 00$ & 12.05 & 0.007 \\
\hline Tst2-197-127 & $8 / 12 / 2003$ & $18: 38$ & 12.20 & $<0.016$ \\
\hline Tst2-197-129 & $8 / 12 / 2003$ & $21: 04$ & 12.30 & $<0.016$ \\
\hline Tst2-197-133 & $8 / 12 / 2003$ & $22: 44$ & 12.37 & 0.007 \\
\hline Tst2-197-135 & $8 / 13 / 2003$ & $5: 42$ & 12.66 & 0.007 \\
\hline Tst2-197-137 & $8 / 13 / 2003$ & $8: 41$ & 12.79 & 0.007 \\
\hline Tst2-197-141 & $8 / 13 / 2003$ & $10: 36$ & 12.87 & 0.006 \\
\hline Tst2-197-145 & $8 / 13 / 2003$ & $17: 51$ & 13.17 & $<0.016$ \\
\hline Tst2-197-147 & $8 / 13 / 2003$ & $20: 50$ & 13.30 & 0.007 \\
\hline Tst2-197-151 & $8 / 13 / 2003$ & $22: 41$ & 13.37 & 0.007 \\
\hline Tst2-197-153 & $8 / 14 / 2003$ & $5: 50$ & 13.67 & 0.009 \\
\hline Tst2-197-155 & $8 / 14 / 2003$ & $8: 49$ & 13.79 & 0.006 \\
\hline Tst2-197-159 & $8 / 14 / 2003$ & $10: 42$ & 13.87 & 0.006 \\
\hline
\end{tabular}


Table A-10: Continued

\begin{tabular}{|c|c|c|c|c|}
\hline Sample Name & Date & Time & $\begin{array}{c}\text { Time elapsed } \\
\text { (days) }\end{array}$ & 2,4-DFBA (mg/L) \\
\hline Tst2-197-161 & $8 / 14 / 2003$ & $17: 49$ & 14.17 & $<0.016$ \\
\hline Tst2-197-161 & $8 / 14 / 2003$ & $17: 49$ & 14.17 & 0.006 \\
\hline Tst2-197-163 & $8 / 14 / 2003$ & $17: 49$ & 14.17 & $<0.016$ \\
\hline Tst2-197-165 & $8 / 14 / 2003$ & $20: 13$ & 14.27 & $<0.016$ \\
\hline Tst2-197-165 & $8 / 14 / 2003$ & $20: 13$ & 14.27 & 0.007 \\
\hline Tst2-197-167 & $8 / 14 / 2003$ & $22: 31$ & 14.37 & 0.008 \\
\hline Tst2-197-171 & $8 / 15 / 2003$ & $6: 03$ & 14.68 & 0.005 \\
\hline Tst2-197-173 & $8 / 15 / 2003$ & $7: 57$ & 14.76 & 0.006 \\
\hline Tst2-197-177 & $8 / 15 / 2003$ & $12: 55$ & 14.97 & $<0.016$ \\
\hline Tst2-197-179 & $8 / 15 / 2003$ & $17: 42$ & 15.16 & 0.007 \\
\hline Tst2-197-183 & $8 / 15 / 2003$ & $20: 19$ & 15.27 & 0.007 \\
\hline Tst2-197-187 & $8 / 15 / 2003$ & $22: 28$ & 15.36 & $<0.016$ \\
\hline Tst2-197-189 & $8 / 16 / 2003$ & $6: 45$ & 15.71 & $<0.016$ \\
\hline Tst2-197-191 & $8 / 16 / 2003$ & 9:08 & 15.81 & $<0.016$ \\
\hline Tst2-197-195 & $8 / 15 / 2003$ & $10: 54$ & 14.88 & $<0.016$ \\
\hline Tst2-197-197 & $8 / 16 / 2003$ & $17: 42$ & 16.16 & 0.007 \\
\hline Tst2-197-201 & $8 / 16 / 2003$ & 21:00 & 16.30 & 0.006 \\
\hline Tst2-197-205 & $8 / 16 / 2003$ & $22: 32$ & 16.37 & 0.005 \\
\hline Tst2-197-207 & $8 / 17 / 2003$ & $6: 40$ & 16.70 & $<0.016$ \\
\hline Tst2-197-209 & $8 / 17 / 2003$ & $8: 32$ & 16.78 & $<0.016$ \\
\hline Tst2-197-213 & $8 / 17 / 2003$ & $11: 12$ & 16.89 & $<0.016$ \\
\hline Tst2-197-215 & $8 / 17 / 2003$ & $17: 35$ & 17.16 & $<0.016$ \\
\hline Tst2-197-219 & $8 / 17 / 2003$ & $20: 14$ & 17.27 & $<0.016$ \\
\hline Tst2-197-223 & $8 / 17 / 2003$ & $22: 44$ & 17.37 & $<0.016$ \\
\hline Tst2-197-225 & $8 / 18 / 2003$ & $5: 40$ & 17.66 & $<0.016$ \\
\hline Tst2-197-227 & $8 / 18 / 2003$ & 9:43 & 17.83 & $<0.016$ \\
\hline Tst2-197-231 & $8 / 18 / 2003$ & $12: 47$ & 17.96 & $<0.016$ \\
\hline Tst2-197-233 & $8 / 18 / 2003$ & $19: 36$ & 18.24 & $<0.016$ \\
\hline Tst2-197-237 & $8 / 18 / 2003$ & $22: 42$ & 18.37 & 0.002 \\
\hline Tst2-197-239 & $8 / 19 / 2003$ & $8: 18$ & 18.77 & $<0.016$ \\
\hline Tst2-197-243 & $8 / 19 / 2003$ & $10: 42$ & 18.87 & $<0.016$ \\
\hline Tst2-197-245 & $8 / 19 / 2003$ & $14: 44$ & 19.04 & $<0.016$ \\
\hline Tst2-197-249 & $8 / 19 / 2003$ & $17: 29$ & 19.16 & $<0.016$ \\
\hline Tst2-197-251 & $8 / 19 / 2003$ & $20: 11$ & 19.27 & $<0.016$ \\
\hline Tst2-197-255 & $8 / 20 / 2003$ & $9: 42$ & 19.83 & 0.004 \\
\hline Tst2-197-257 & $8 / 20 / 2003$ & $11: 45$ & 19.92 & 0.004 \\
\hline Tst2-197-261 & $8 / 20 / 2003$ & $17: 32$ & 20.16 & $<0.016$ \\
\hline Tst2-197-263 & $8 / 20 / 2003$ & $20: 15$ & 20.27 & $<0.016$ \\
\hline Tst2-197-267 & $8 / 21 / 2003$ & 9:06 & 20.81 & $<0.016$ \\
\hline Tst2-197-269 & $8 / 21 / 2003$ & $14: 47$ & 21.04 & $<0.016$ \\
\hline Tst2-197-279 & $8 / 25 / 2003$ & $8: 34$ & 24.78 & $<0.016$ \\
\hline Tst2-197-281 & $8 / 25 / 2003$ & $15: 30$ & 25.07 & 0.003 \\
\hline Tst2-197-285 & $8 / 26 / 2003$ & $9: 30$ & 25.82 & $<0.016$ \\
\hline
\end{tabular}


Table A-10: Continued

\begin{tabular}{|c|c|c|c|c|}
\hline Sample Name & Date & Time & $\begin{array}{c}\text { Time elapsed } \\
\text { (days) }\end{array}$ & 2,4-DFBA (mg/L) \\
\hline Tst2-197-287 & $8 / 26 / 2003$ & $15: 34$ & 26.08 & $<0.016$ \\
\hline Tst2-197-291 & $8 / 27 / 2003$ & $8: 51$ & 26.80 & $<0.016$ \\
\hline Tst2-197-293 & $8 / 27 / 2003$ & $14: 25$ & 27.03 & $<0.016$ \\
\hline Tst2-197-297 & $8 / 28 / 2003$ & $10: 02$ & 27.85 & $<0.016$ \\
\hline Tst2-197-299 & $8 / 28 / 2003$ & $15: 25$ & 28.07 & $<0.016$ \\
\hline Tst2-197-303 & $8 / 29 / 2003$ & $14: 55$ & 29.05 & $<0.016$ \\
\hline Tst2-197-309 & $9 / 3 / 2003$ & $12: 20$ & 33.94 & $<0.016$ \\
\hline Tst2-197-311 & $9 / 4 / 2003$ & $13: 55$ & 35.01 & $<0.016$ \\
\hline Tst2-197-315 & $9 / 8 / 2003$ & $13: 34$ & 38.99 & 0.009 \\
\hline Tst2-197-317 & $9 / 9 / 2003$ & $11: 12$ & 39.89 & 0.009 \\
\hline Tst2-197-321 & $9 / 10 / 2003$ & $11: 10$ & 40.89 & 0.009 \\
\hline Tst2-197-323 & $9 / 11 / 2003$ & $11: 15$ & 41.90 & $<0.016$ \\
\hline Tst2-197-327 & $9 / 15 / 2003$ & $10: 35$ & 45.87 & 0.009 \\
\hline Tst2-197-329 & $9 / 16 / 2003$ & $8: 23$ & 46.78 & 0.009 \\
\hline Tst2-197-333 & $9 / 18 / 2003$ & $10: 10$ & 48.85 & $<0.016$ \\
\hline Tst2-197-335 & $9 / 22 / 2003$ & $15: 10$ & 53.06 & $<0.016$ \\
\hline Tst2-197-339 & $9 / 25 / 2003$ & $14: 55$ & 56.05 & $<0.016$ \\
\hline
\end{tabular}

Table A-11: HPLC data from test 2, well 199

\begin{tabular}{|c|c|c|c|c|}
\hline Sample Name & Date & Time & $\begin{array}{c}\text { Time elapsed } \\
\text { (days) }\end{array}$ & 2,4-DFBA (mg/L) \\
\hline Tst2-199-006 & $8 / 4 / 2003$ & $18: 52$ & 4.21 & 0.077 \\
\hline Tst2-199-007 & $8 / 4 / 2003$ & $22: 22$ & 4.36 & 0.082 \\
\hline Tst2-199-011 & $8 / 5 / 2003$ & $5: 35$ & 4.66 & 0.087 \\
\hline Tst2-199-033 & $8 / 6 / 2003$ & $9: 00$ & 5.80 & 0.096 \\
\hline Tst2-199-034 & $8 / 6 / 2003$ & $12: 39$ & 5.95 & 0.109 \\
\hline Tst2-199-051 & $8 / 7 / 2003$ & $12: 05$ & 6.93 & 0.112 \\
\hline Tst2-199-055 & $8 / 7 / 2003$ & $17: 44$ & 7.17 & 0.132 \\
\hline Tst2-199-060 & $8 / 7 / 2003$ & $20: 15$ & 7.27 & 0.137 \\
\hline Tst2-199-090 & $8 / 8 / 2003$ & $21: 08$ & 8.31 & 0.140 \\
\hline Tst2-199-094 & $8 / 8 / 2003$ & $22: 34$ & 8.37 & 0.141 \\
\hline Tst2-199-097 & $8 / 9 / 2003$ & $5: 37$ & 8.66 & 0.132 \\
\hline Tst2-199-105 & $8 / 9 / 2003$ & $10: 45$ & 8.88 & 0.133 \\
\hline Tst2-199-109 & $8 / 9 / 2003$ & $12: 52$ & 8.96 & 0.134 \\
\hline Tst2-199-117 & $8 / 9 / 2003$ & $18: 50$ & 9.21 & 0.133 \\
\hline Tst2-199-121 & $8 / 9 / 2003$ & $20: 27$ & 9.28 & 0.134 \\
\hline Tst2-199-125 & $8 / 9 / 2003$ & $22: 00$ & 9.34 & 0.135 \\
\hline Tst2-199-157 & $8 / 10 / 2003$ & $21: 38$ & 10.33 & 0.121 \\
\hline Tst2-199-163 & $8 / 10 / 2003$ & $23: 22$ & 10.40 & 0.114 \\
\hline Tst2-199-164 & $8 / 11 / 2003$ & $6: 10$ & 10.68 & 0.112 \\
\hline Tst2-199-169 & $8 / 11 / 2003$ & $12: 20$ & 10.94 & 0.102 \\
\hline Tst2-199-173 & $8 / 11 / 2003$ & $17: 30$ & 11.16 & 0.096 \\
\hline
\end{tabular}


Table A-11: Continued

\begin{tabular}{|c|c|c|c|c|}
\hline Tst2-199-177 & $8 / 11 / 2003$ & $18: 42$ & 11.21 & 0.091 \\
\hline Tst2-199-185 & $8 / 11 / 2003$ & 20:07 & 11.27 & 0.103 \\
\hline Tst2-199-191 & $8 / 11 / 2003$ & $22: 30$ & 11.36 & 0.092 \\
\hline Tst2-199-229 & $8 / 13 / 2003$ & $17: 20$ & 13.15 & 0.073 \\
\hline Tst2-199-233 & $8 / 13 / 2003$ & $20: 10$ & 13.27 & 0.066 \\
\hline Tst2-199-235 & $8 / 13 / 2003$ & $22: 41$ & 13.37 & 0.066 \\
\hline Tst2-199-237 & $8 / 14 / 2003$ & $5: 55$ & 13.67 & 0.073 \\
\hline Tst2-199-241 & $8 / 14 / 2003$ & $8: 53$ & 13.80 & 0.060 \\
\hline Tst2-199-243 & $8 / 14 / 2003$ & $10: 50$ & 13.88 & 0.064 \\
\hline Tst2-199-247 & $8 / 14 / 2003$ & $6: 30$ & 13.70 & 0.069 \\
\hline Tst2-199-249 & $8 / 14 / 2003$ & $20: 26$ & 14.28 & 0.057 \\
\hline Tst2-199-253 & $8 / 14 / 2003$ & $22: 37$ & 14.37 & 0.052 \\
\hline Tst2-199-255 & $8 / 15 / 2003$ & $6: 08$ & 14.68 & 0.057 \\
\hline Tst2-199-259 & $8 / 15 / 2003$ & 8:03 & 14.76 & 0.053 \\
\hline Tst2-199-261 & $8 / 15 / 2003$ & $12: 59$ & 14.97 & 0.050 \\
\hline Tst2-199-275 & $8 / 16 / 2003$ & 9:23 & 15.82 & 0.046 \\
\hline Tst2-199-277 & $8 / 16 / 2003$ & $10: 58$ & 15.88 & 0.041 \\
\hline Tst2-199-281 & $8 / 16 / 2003$ & $17: 11$ & 16.14 & 0.041 \\
\hline Tst2-199-287 & $8 / 16 / 2003$ & $22: 27$ & 16.36 & 0.034 \\
\hline Tst2-199-289 & $8 / 17 / 2003$ & $6: 54$ & 16.71 & 0.035 \\
\hline Tst2-199-291 & $8 / 17 / 2003$ & $11: 15$ & 16.90 & 0.027 \\
\hline Tst2-199-292 & $8 / 17 / 2003$ & $17: 20$ & 17.15 & 0.037 \\
\hline Tst2-199-294 & $8 / 17 / 2003$ & $22: 46$ & 17.38 & 0.027 \\
\hline Tst2-199-298 & $8 / 18 / 2003$ & $19: 20$ & 18.23 & 0.020 \\
\hline Tst2-199-299 & $8 / 18 / 2003$ & $20: 53$ & 18.30 & 0.025 \\
\hline Tst2-199-300 & $8 / 18 / 2003$ & $22: 46$ & 18.38 & 0.021 \\
\hline Tst2-199-302 & $8 / 19 / 2003$ & $10: 28$ & 18.86 & 0.024 \\
\hline Tst2-199-309 & $8 / 20 / 2003$ & $17: 43$ & 20.17 & 0.016 \\
\hline Tst2-199-311 & $8 / 20 / 2003$ & $20: 30$ & 20.28 & 0.025 \\
\hline Tst2-199-315 & $8 / 21 / 2003$ & $8: 50$ & 20.80 & 0.020 \\
\hline Tst2-199-321 & $8 / 22 / 2003$ & $10: 40$ & 21.87 & 0.020 \\
\hline Tst2-199-327 & $8 / 25 / 2003$ & $8: 10$ & 24.77 & 0.018 \\
\hline Tst2-199-332 & $8 / 26 / 2003$ & 9:00 & 25.80 & 0.008 \\
\hline
\end{tabular}

Table A-12: HPLC data from test 2, well 200

\begin{tabular}{|c|c|c|c|c|}
\hline Sample Name & Date & Time & $\begin{array}{c}\text { Time elapsed } \\
\text { (days) }\end{array}$ & 2,4-DFBA (mg/L) \\
\hline Tst2-200-001 & $8 / 1 / 2003$ & $12: 22$ & 0.94 & $<0.016$ \\
\hline Tst2-200-003 & $8 / 1 / 2003$ & $15: 32$ & 1.07 & $<0.016$ \\
\hline Tst2-200-007 & $8 / 1 / 2003$ & $18: 23$ & 1.19 & $<0.016$ \\
\hline Tst2-200-015 & $8 / 2 / 2003$ & $5: 20$ & 1.65 & $<0.016$ \\
\hline Tst2-200-019 & $8 / 2 / 2003$ & $8: 32$ & 1.78 & $<0.016$ \\
\hline Tst2-200-021 & $8 / 2 / 2003$ & $11: 41$ & 1.91 & $<0.016$ \\
\hline
\end{tabular}


Table A-12: Continued

\begin{tabular}{|c|c|c|c|c|}
\hline Sample Name & Date & Time & $\begin{array}{c}\text { Time elapsed } \\
\text { (days) }\end{array}$ & 2,4-DFBA (mg/L) \\
\hline Tst2-200-025 & $8 / 2 / 2003$ & $17: 38$ & 2.16 & $<0.016$ \\
\hline Tst2-200-029 & $8 / 2 / 2003$ & 19:06 & 2.22 & $<0.016$ \\
\hline Tst2-200-033 & $8 / 2 / 2003$ & $20: 51$ & 2.30 & $<0.016$ \\
\hline Tst2-200-037 & $8 / 2 / 2003$ & $22: 18$ & 2.36 & $<0.016$ \\
\hline Tst2-200-041 & $8 / 2 / 2003$ & $23: 48$ & 2.42 & 0.003 \\
\hline Tst2-200-045 & $8 / 3 / 2003$ & $5: 24$ & 2.65 & $<0.016$ \\
\hline Tst2-200-049 & $8 / 3 / 2003$ & $7: 19$ & 2.73 & $<0.016$ \\
\hline Tst2-200-053 & $8 / 3 / 2003$ & $8: 33$ & 2.78 & $<0.016$ \\
\hline Tst2-200-061 & $8 / 3 / 2003$ & $13: 08$ & 2.97 & $<0.016$ \\
\hline Tst2-200-065 & $8 / 3 / 2003$ & $18: 10$ & 3.18 & $<0.016$ \\
\hline Tst2-200-069 & $8 / 3 / 2003$ & $18: 49$ & 3.21 & $<0.016$ \\
\hline Tst2-200-073 & $8 / 3 / 2003$ & $21: 11$ & 3.31 & $<0.016$ \\
\hline Tst2-200-077 & $8 / 3 / 2003$ & $22: 14$ & 3.35 & $<0.016$ \\
\hline Tst2-200-081 & 8/3/2003 & $23: 36$ & 3.41 & $<0.016$ \\
\hline Tst2-200-089 & $8 / 4 / 2003$ & $7: 35$ & 3.74 & 0.004 \\
\hline Tst2-200-093 & $8 / 4 / 2003$ & $8: 22$ & 3.78 & 0.009 \\
\hline Tst2-200-097 & $8 / 4 / 2003$ & $10: 30$ & 3.86 & 0.008 \\
\hline Tst2-200-101 & $8 / 4 / 2003$ & $11: 33$ & 3.91 & 0.008 \\
\hline Tst2-200-105 & $8 / 4 / 2003$ & $17: 29$ & 4.16 & 0.012 \\
\hline Tst2-200-109 & $8 / 4 / 2003$ & 21:07 & 4.31 & 0.017 \\
\hline Tst2-200-113 & $8 / 4 / 2003$ & $22: 26$ & 4.36 & 0.019 \\
\hline Tst2-200-117 & $8 / 4 / 2003$ & $23: 38$ & 4.41 & 0.019 \\
\hline Tst2-200-121 & $8 / 5 / 2003$ & $5: 45$ & 4.67 & 0.023 \\
\hline Tst2-200-125 & $8 / 5 / 2003$ & $8: 20$ & 4.77 & 0.024 \\
\hline Tst2-200-129 & $8 / 5 / 2003$ & $9: 45$ & 4.83 & 0.023 \\
\hline Tst2-200-133 & $8 / 5 / 2003$ & $12: 52$ & 4.96 & 0.023 \\
\hline Tst2-200-137 & $8 / 5 / 2003$ & $17: 31$ & 5.16 & 0.024 \\
\hline Tst2-200-141 & $8 / 5 / 2003$ & $17: 15$ & 5.15 & 0.023 \\
\hline Tst2-200-145 & $8 / 5 / 2003$ & $20: 32$ & 5.28 & 0.025 \\
\hline Tst2-200-149 & $8 / 5 / 2003$ & 23:13 & 5.39 & 0.024 \\
\hline Tst2-200-153 & $8 / 6 / 2003$ & $5: 50$ & 5.67 & 0.024 \\
\hline Tst2-200-157 & 8/6/2003 & $7: 25$ & 5.74 & 0.022 \\
\hline Tst2-200-161 & $8 / 6 / 2003$ & $9: 36$ & 5.83 & 0.024 \\
\hline Tst2-200-169 & 8/6/2003 & $17: 28$ & 6.15 & 0.021 \\
\hline Tst2-200-173 & $8 / 6 / 2003$ & 22:00 & 6.34 & 0.022 \\
\hline Tst2-200-177 & $8 / 6 / 2003$ & $23: 13$ & 6.39 & 0.021 \\
\hline Tst2-200-181 & $8 / 7 / 2003$ & $5: 14$ & 6.65 & 0.019 \\
\hline Tst2-200-185 & $8 / 7 / 2003$ & $8: 51$ & 6.80 & 0.018 \\
\hline Tst2-200-189 & 8/7/2003 & $11: 54$ & 6.92 & 0.018 \\
\hline Tst2-200-193 & $8 / 7 / 2003$ & $17: 45$ & 7.17 & 0.020 \\
\hline Tst2-200-201 & 8/7/2003 & $21: 38$ & 7.33 & 0.018 \\
\hline Tst2-200-205 & 8/7/2003 & $22: 53$ & 7.38 & 0.017 \\
\hline Tst2-200-209 & $8 / 8 / 2003$ & $5: 29$ & 7.66 & 0.018 \\
\hline
\end{tabular}


Table A-12: Continued

\begin{tabular}{|c|c|c|c|c|}
\hline Sample Name & Date & Time & $\begin{array}{c}\text { Time elapsed } \\
\text { (days) }\end{array}$ & 2,4-DFBA (mg/L) \\
\hline Tst2-200-213 & 8/8/2003 & $8: 34$ & 7.78 & 0.019 \\
\hline Tst2-200-217 & $8 / 8 / 2003$ & $10: 08$ & 7.85 & 0.018 \\
\hline Tst2-200-221 & $8 / 8 / 2003$ & $12: 27$ & 7.95 & 0.018 \\
\hline Tst2-200-225 & 8/8/2003 & $17: 40$ & 8.16 & 0.021 \\
\hline Tst2-200-229 & $8 / 8 / 2003$ & $19: 38$ & 8.25 & 0.022 \\
\hline Tst2-200-233 & $8 / 8 / 2003$ & 21:10 & 8.31 & 0.022 \\
\hline Tst2-200-237 & $8 / 8 / 2003$ & $22: 38$ & 8.37 & 0.025 \\
\hline Tst2-200-241 & $8 / 9 / 2003$ & $5: 32$ & 8.66 & 0.027 \\
\hline Tst2-200-245 & $8 / 9 / 2003$ & $8: 40$ & 8.79 & 0.029 \\
\hline Tst2-200-249 & $8 / 9 / 2003$ & $10: 40$ & 8.87 & 0.030 \\
\hline Tst2-200-253 & $8 / 9 / 2003$ & $12: 47$ & 8.96 & 0.035 \\
\hline Tst2-200-257 & $8 / 9 / 2003$ & $18: 00$ & 9.18 & 0.033 \\
\hline Tst2-200-261 & $8 / 9 / 2003$ & $18: 55$ & 9.22 & 0.032 \\
\hline Tst2-200-265 & 8/9/2003 & $20: 29$ & 9.28 & 0.035 \\
\hline Tst2-200-273 & 8/9/2003 & $22: 55$ & 9.38 & 0.037 \\
\hline Tst2-200-277 & $8 / 10 / 2003$ & $5: 40$ & 9.66 & 0.034 \\
\hline Tst2-200-281 & $8 / 10 / 2003$ & $8: 43$ & 9.79 & 0.038 \\
\hline Tst2-200-285 & $8 / 10 / 2003$ & $10: 37$ & 9.87 & 0.040 \\
\hline Tst2-200-289 & $8 / 10 / 2003$ & $12: 34$ & 9.95 & 0.037 \\
\hline Tst2-200-293 & $8 / 10 / 2003$ & 19:02 & 10.22 & 0.037 \\
\hline Tst2-200-294 & $8 / 10 / 2003$ & 19:02 & 10.22 & 0.038 \\
\hline Tst2-200-297 & $8 / 10 / 2003$ & $23: 27$ & 10.40 & 0.046 \\
\hline Tst2-200-297 & $8 / 10 / 2003$ & $23: 27$ & 10.40 & 0.037 \\
\hline Tst2-200-301 & $8 / 10 / 2003$ & $21: 40$ & 10.33 & 0.045 \\
\hline Tst2-200-307 & $8 / 11 / 2003$ & $6: 20$ & 10.69 & 0.042 \\
\hline Tst2-200-310 & $8 / 11 / 2003$ & $8: 49$ & 10.79 & 0.047 \\
\hline Tst2-200-315 & $8 / 11 / 2003$ & $12: 18$ & 10.94 & 0.046 \\
\hline Tst2-200-318 & $8 / 11 / 2003$ & $17: 31$ & 11.16 & 0.048 \\
\hline Tst2-200-322 & $8 / 11 / 2003$ & $18: 42$ & 11.21 & 0.047 \\
\hline Tst2-200-326 & $8 / 11 / 2003$ & $20: 12$ & 11.27 & 0.048 \\
\hline Tst2-200-331 & $8 / 11 / 2003$ & $22: 36$ & 11.37 & 0.049 \\
\hline Tst2-200-335 & $8 / 12 / 2003$ & $6: 15$ & 11.69 & 0.046 \\
\hline Tst2-200-339 & $8 / 12 / 2003$ & $8: 38$ & 11.79 & 0.044 \\
\hline Tst2-200-343 & $8 / 12 / 2003$ & $10: 55$ & 11.88 & 0.040 \\
\hline Tst2-200-351 & $8 / 12 / 2003$ & $17: 58$ & 12.18 & 0.045 \\
\hline Tst2-200-355 & $8 / 12 / 2003$ & $20: 25$ & 12.28 & 0.041 \\
\hline Tst2-200-357 & $8 / 12 / 2003$ & $22: 55$ & 12.38 & 0.043 \\
\hline Tst2-200-359 & $8 / 13 / 2003$ & $5: 53$ & 12.67 & 0.037 \\
\hline Tst2-200-363 & $8 / 13 / 2003$ & $8: 54$ & 12.80 & 0.040 \\
\hline Tst2-200-365 & $8 / 13 / 2003$ & $10: 46$ & 12.88 & 0.034 \\
\hline Tst2-200-369 & $8 / 13 / 2003$ & $17: 23$ & 13.15 & 0.036 \\
\hline Tst2-200-373 & $8 / 13 / 2003$ & $20: 14$ & 13.27 & 0.033 \\
\hline Tst2-200-375 & $8 / 13 / 2003$ & $22: 53$ & 13.38 & 0.027 \\
\hline
\end{tabular}


Table A-12: Continued

\begin{tabular}{|c|c|c|c|c|}
\hline Sample Name & Date & Time & $\begin{array}{c}\text { Time elapsed } \\
\text { (days) }\end{array}$ & 2,4-DFBA (mg/L) \\
\hline Tst2-200-380 & $8 / 14 / 2003$ & $8: 57$ & 13.80 & 0.035 \\
\hline Tst2-200-385 & $8 / 14 / 2003$ & $10: 38$ & 13.87 & 0.033 \\
\hline Tst2-200-387 & $8 / 14 / 2003$ & $17: 27$ & 14.15 & 0.033 \\
\hline Tst2-200-389 & $8 / 14 / 2003$ & $20: 27$ & 14.28 & 0.027 \\
\hline Tst2-200-393 & $8 / 14 / 2003$ & $22: 44$ & 14.37 & 0.026 \\
\hline Tst2-200-395 & $8 / 15 / 2003$ & $6: 12$ & 14.69 & 0.025 \\
\hline Tst2-200-398 & $8 / 15 / 2003$ & 8:09 & 14.77 & 0.025 \\
\hline Tst2-200-402 & $8 / 15 / 2003$ & 13:06 & 14.97 & 0.020 \\
\hline Tst2-200-405 & $8 / 15 / 2003$ & $17: 20$ & 15.15 & 0.026 \\
\hline Tst2-200-409 & $8 / 15 / 2003$ & $19: 45$ & 15.25 & 0.022 \\
\hline Tst2-200-423 & $8 / 16 / 2003$ & $17: 16$ & 16.15 & 0.016 \\
\hline Tst2-200-427 & $8 / 18 / 2003$ & 19:20 & 18.23 & 0.012 \\
\hline Tst2-200-429 & $8 / 18 / 2003$ & $20: 57$ & 18.30 & 0.013 \\
\hline Tst2-200-431 & $8 / 18 / 2003$ & $22: 50$ & 18.38 & 0.014 \\
\hline Tst2-200-435 & $8 / 19 / 2003$ & $7: 57$ & 18.76 & 0.011 \\
\hline Tst2-200-437 & $8 / 19 / 2003$ & $10: 29$ & 18.86 & 0.013 \\
\hline Tst2-200-441 & $8 / 19 / 2003$ & $14: 27$ & 19.03 & 0.011 \\
\hline Tst2-200-443 & $8 / 19 / 2003$ & $17: 41$ & 19.16 & 0.009 \\
\hline Tst2-200-447 & $8 / 19 / 2003$ & $20: 33$ & 19.28 & 0.011 \\
\hline Tst2-200-449 & $8 / 20 / 2003$ & $8: 32$ & 19.78 & 0.010 \\
\hline Tst2-200-453 & $8 / 20 / 2003$ & $11: 27$ & 19.90 & 0.009 \\
\hline Tst2-200-455 & $8 / 20 / 2003$ & $17: 43$ & 20.17 & 0.009 \\
\hline Tst2-200-459 & $8 / 20 / 2003$ & $20: 36$ & 20.29 & 0.008 \\
\hline Tst2-200-467 & $8 / 22 / 2003$ & $10: 33$ & 21.87 & 0.005 \\
\hline Tst2-200-473 & $8 / 25 / 2003$ & $8: 12$ & 24.77 & 0.004 \\
\hline Tst2-200-479 & $8 / 26 / 2003$ & 9:05 & 25.81 & 0.003 \\
\hline Tst2-200-485 & $8 / 27 / 2003$ & $8: 35$ & 26.78 & $<0.016$ \\
\hline Tst2-200-489 & $8 / 27 / 2003$ & $14: 08$ & 27.02 & $<0.016$ \\
\hline Tst2-200-491 & $8 / 28 / 2003$ & $9: 41$ & 27.83 & $<0.016$ \\
\hline Tst2-200-495 & $8 / 28 / 2003$ & $15: 10$ & 28.06 & $<0.016$ \\
\hline Tst2-200-497 & $8 / 29 / 2003$ & 15:07 & 29.06 & $<0.016$ \\
\hline Tst2-200-501 & $9 / 2 / 2003$ & $9: 44$ & 32.83 & $<0.016$ \\
\hline Tst2-200-503 & $9 / 3 / 2003$ & $12: 06$ & 33.93 & $<0.016$ \\
\hline Tst2-200-507 & $9 / 4 / 2003$ & $13: 10$ & 34.98 & $<0.016$ \\
\hline Tst2-200-509 & 9/8/2003 & $13: 19$ & 38.98 & $<0.016$ \\
\hline Tst2-200-513 & 9/9/2003 & $11: 00$ & 39.89 & $<0.016$ \\
\hline Tst2-200-515 & $9 / 10 / 2003$ & $10: 56$ & 40.88 & $<0.016$ \\
\hline Tst2-200-519 & 9/11/2003 & $10: 59$ & 41.88 & $<0.016$ \\
\hline Tst2-200-521 & 9/15/2003 & $10: 20$ & 45.86 & $<0.016$ \\
\hline Tst2-200-525 & 9/16/2003 & $8: 10$ & 46.77 & $<0.016$ \\
\hline Tst2-200-527 & $9 / 18 / 2003$ & $9: 53$ & 48.84 & $<0.016$ \\
\hline Tst2-200-531 & 9/22/2003 & $14: 57$ & 53.05 & $<0.016$ \\
\hline
\end{tabular}


Table A-13: HPLC data from test 2, well 202

\begin{tabular}{|c|c|c|c|c|}
\hline Sample Name & Date & Time & $\begin{array}{c}\text { Time elapsed } \\
\text { (days) }\end{array}$ & 2,4-DFBA (mg/L) \\
\hline Tst2-202-001 & $8 / 1 / 2003$ & $12: 31$ & 0.95 & 0.002 \\
\hline Tst2-202-003 & $8 / 1 / 2003$ & $15: 42$ & 1.08 & $<0.016$ \\
\hline Tst2-202-007 & $8 / 1 / 2003$ & 18:02 & 1.18 & $<0.016$ \\
\hline Tst2-202-009 & $8 / 1 / 2003$ & $20: 52$ & 1.30 & $<0.016$ \\
\hline Tst2-202-013 & $8 / 1 / 2003$ & $23: 32$ & 1.41 & $<0.016$ \\
\hline Tst2-202-015 & $8 / 2 / 2003$ & $5: 31$ & 1.66 & $<0.016$ \\
\hline Tst2-202-021 & $8 / 2 / 2003$ & $11: 51$ & 1.92 & $<0.016$ \\
\hline Tst2-202-025 & $8 / 2 / 2003$ & $17: 27$ & 2.15 & $<0.016$ \\
\hline Tst2-202-027 & $8 / 2 / 2003$ & 21:02 & 2.30 & $<0.016$ \\
\hline Tst2-202-031 & $8 / 2 / 2003$ & $23: 16$ & 2.40 & $<0.016$ \\
\hline Tst2-202-033 & $8 / 3 / 2003$ & $5: 35$ & 2.66 & $<0.016$ \\
\hline Tst2-202-039 & $8 / 3 / 2003$ & $12: 54$ & 2.96 & $<0.016$ \\
\hline Tst2-202-043 & $8 / 3 / 2003$ & $17: 53$ & 3.17 & $<0.016$ \\
\hline Tst2-202-045 & $8 / 3 / 2003$ & $20: 59$ & 3.30 & $<0.016$ \\
\hline Tst2-202-049 & 8/3/2003 & 23:23 & 3.40 & $<0.016$ \\
\hline Tst2-202-051 & $8 / 4 / 2003$ & $6: 05$ & 3.68 & 0.003 \\
\hline Tst2-202-055 & $8 / 4 / 2003$ & $8: 36$ & 3.79 & 0.008 \\
\hline Tst2-202-059 & $8 / 4 / 2003$ & $11: 07$ & 3.89 & 0.011 \\
\hline Tst2-202-065 & $8 / 4 / 2003$ & $20: 31$ & 4.28 & 0.017 \\
\hline Tst2-202-071 & $8 / 5 / 2003$ & $6: 05$ & 4.68 & 0.038 \\
\hline Tst2-202-073 & $8 / 5 / 2003$ & $8: 57$ & 4.80 & 0.039 \\
\hline Tst2-202-077 & $8 / 5 / 2003$ & $14: 08$ & 5.02 & 0.044 \\
\hline Tst2-202-081 & $8 / 5 / 2003$ & $17: 46$ & 5.17 & 0.051 \\
\hline Tst2-202-085 & $8 / 5 / 2003$ & 19:00 & 5.22 & 0.053 \\
\hline Tst2-202-089 & $8 / 5 / 2003$ & $21: 25$ & 5.32 & 0.053 \\
\hline Tst2-202-097 & $8 / 6 / 2003$ & $6: 20$ & 5.69 & 0.071 \\
\hline Tst2-202-099 & $8 / 6 / 2003$ & $7: 40$ & 5.75 & 0.072 \\
\hline Tst2-202-103 & $8 / 6 / 2003$ & $9: 48$ & 5.84 & 0.082 \\
\hline Tst2-202-107 & 8/6/2003 & $13: 08$ & 5.97 & 0.077 \\
\hline Tst2-202-111 & $8 / 6 / 2003$ & $17: 48$ & 6.17 & 0.079 \\
\hline Tst2-202-115 & $8 / 6 / 2003$ & $21: 37$ & 6.33 & 0.080 \\
\hline Tst2-202-117 & $8 / 6 / 2003$ & $23: 21$ & 6.40 & 0.086 \\
\hline Tst2-202-121 & $8 / 7 / 2003$ & $5: 25$ & 6.65 & 0.096 \\
\hline Tst2-202-125 & $8 / 7 / 2003$ & 9:01 & 6.80 & 0.098 \\
\hline Tst2-202-129 & 8/7/2003 & $12: 30$ & 6.95 & 0.103 \\
\hline Tst2-202-133 & 8/7/2003 & $18: 16$ & 7.19 & 0.110 \\
\hline Tst2-202-137 & $8 / 7 / 2003$ & $20: 48$ & 7.29 & 0.117 \\
\hline Tst2-202-145 & $8 / 8 / 2003$ & $5: 56$ & 7.67 & 0.124 \\
\hline Tst2-202-153 & 8/8/2003 & $10: 18$ & 7.86 & 0.142 \\
\hline Tst2-202-161 & 8/8/2003 & $17: 53$ & 8.17 & 0.154 \\
\hline Tst2-202-165 & $8 / 8 / 2003$ & $21: 20$ & 8.32 & 0.158 \\
\hline Tst2-202-169 & $8 / 8 / 2003$ & $22: 46$ & 8.38 & 0.171 \\
\hline Tst2-202-183 & $8 / 9 / 2003$ & $18: 20$ & 9.19 & 0.191 \\
\hline
\end{tabular}


Table A-13: Continued

\begin{tabular}{|c|c|c|c|c|}
\hline Sample Name & Date & Time & $\begin{array}{c}\text { Time elapsed } \\
\text { (days) }\end{array}$ & 2,4-DFBA (mg/L) \\
\hline Tst2-202-187 & 8/9/2003 & $20: 35$ & 9.28 & 0.214 \\
\hline Tst2-202-199 & $8 / 10 / 2003$ & $8: 55$ & 9.80 & 0.219 \\
\hline Tst2-202-201 & $8 / 10 / 2003$ & $12: 17$ & 9.94 & 0.253 \\
\hline Tst2-202-205 & $8 / 10 / 2003$ & $19: 10$ & 10.23 & 0.263 \\
\hline Tst2-202-205 & $8 / 11 / 2003$ & $20: 22$ & 11.28 & 0.320 \\
\hline Tst2-202-209 & $8 / 11 / 2003$ & $22: 46$ & 11.38 & 0.287 \\
\hline Tst2-202-213 & $8 / 12 / 2003$ & $6: 25$ & 11.69 & 0.290 \\
\hline Tst2-202-221 & $8 / 12 / 2003$ & $12: 54$ & 11.96 & 0.312 \\
\hline Tst2-202-231 & $8 / 12 / 2003$ & $20: 36$ & 12.29 & 0.320 \\
\hline Tst2-202-247 & $8 / 13 / 2003$ & $7: 10$ & 12.73 & 0.342 \\
\hline Tst2-202-253 & $8 / 13 / 2003$ & $11: 13$ & 12.89 & 0.330 \\
\hline Tst2-202-257 & $8 / 13 / 2003$ & $17: 34$ & 13.16 & 0.309 \\
\hline Tst2-202-263 & $8 / 13 / 2003$ & $20: 27$ & 13.28 & 0.309 \\
\hline Tst2-202-267 & $8 / 13 / 2003$ & $22: 11$ & 13.35 & 0.316 \\
\hline Tst2-202-273 & $8 / 14 / 2003$ & $6: 10$ & 13.68 & 0.336 \\
\hline Tst2-202-277 & $8 / 14 / 2003$ & $7: 02$ & 13.72 & 0.334 \\
\hline Tst2-202-281 & $8 / 14 / 2003$ & $9: 15$ & 13.81 & 0.340 \\
\hline Tst2-202-287 & $8 / 14 / 2003$ & $11: 05$ & 13.89 & 0.332 \\
\hline Tst2-202-289 & $8 / 14 / 2003$ & $17: 14$ & 14.15 & 0.336 \\
\hline Tst2-202-293 & $8 / 14 / 2003$ & $18: 40$ & 14.20 & 0.325 \\
\hline Tst2-202-297 & $8 / 14 / 2003$ & $20: 37$ & 14.29 & 0.337 \\
\hline Tst2-202-301 & $8 / 14 / 2003$ & $22: 55$ & 14.38 & 0.325 \\
\hline Tst2-202-305 & $8 / 15 / 2003$ & $6: 20$ & 14.69 & 0.337 \\
\hline Tst2-202-309 & $8 / 15 / 2003$ & $8: 17$ & 14.77 & 0.336 \\
\hline Tst2-202-313 & $8 / 15 / 2003$ & $13: 13$ & 14.98 & 0.346 \\
\hline Tst2-202-317 & $8 / 15 / 2003$ & $17: 34$ & 15.16 & 0.325 \\
\hline Tst2-202-321 & $8 / 15 / 2003$ & 19:55 & 15.26 & 0.312 \\
\hline Tst2-202-325 & $8 / 15 / 2003$ & $22: 51$ & 15.38 & 0.317 \\
\hline Tst2-202-329 & $8 / 16 / 2003$ & $7: 01$ & 15.72 & 0.312 \\
\hline Tst2-202-331 & $8 / 16 / 2003$ & $8: 15$ & 15.77 & 0.324 \\
\hline Tst2-202-335 & $8 / 16 / 2003$ & 9:30 & 15.82 & 0.303 \\
\hline Tst2-202-337 & $8 / 16 / 2003$ & 11:11 & 15.89 & 0.305 \\
\hline Tst2-202-341 & $8 / 16 / 2003$ & $17: 27$ & 16.15 & 0.327 \\
\hline Tst2-202-343 & $8 / 16 / 2003$ & $20: 17$ & 16.27 & 0.291 \\
\hline Tst2-202-349 & $8 / 17 / 2003$ & 7:03 & 16.72 & 0.321 \\
\hline Tst2-202-355 & $8 / 17 / 2003$ & $10: 05$ & 16.85 & 0.287 \\
\hline Tst2-202-361 & $8 / 17 / 2003$ & $17: 44$ & 17.17 & 0.290 \\
\hline Tst2-202-365 & $8 / 17 / 2003$ & $20: 31$ & 17.28 & 0.285 \\
\hline Tst2-202-370 & $8 / 18 / 2003$ & $6: 20$ & 17.69 & 0.291 \\
\hline Tst2-202-375 & $8 / 18 / 2003$ & $9: 54$ & 17.84 & 0.302 \\
\hline Tst2-202-377 & $8 / 18 / 2003$ & $13: 11$ & 17.98 & 0.276 \\
\hline Tst2-202-383 & $8 / 18 / 2003$ & 21:03 & 18.30 & 0.295 \\
\hline Tst2-202-385 & $8 / 18 / 2003$ & $22: 57$ & 18.38 & 0.294 \\
\hline
\end{tabular}


Table A-13: Continued

\begin{tabular}{|c|c|c|c|c|}
\hline Sample Name & Date & Time & $\begin{array}{c}\text { Time elapsed } \\
\text { (days) }\end{array}$ & 2,4-DFBA (mg/L) \\
\hline Tst2-202-389 & $8 / 19 / 2003$ & $8: 48$ & 18.79 & 0.264 \\
\hline Tst2-202-395 & $8 / 19 / 2003$ & $17: 56$ & 19.17 & 0.285 \\
\hline Tst2-202-397 & $8 / 19 / 2003$ & $20: 42$ & 19.29 & 0.282 \\
\hline Tst2-202-401 & $8 / 20 / 2003$ & $10: 01$ & 19.84 & 0.282 \\
\hline Tst2-202-403 & $8 / 20 / 2003$ & $11: 54$ & 19.92 & 0.252 \\
\hline Tst2-202-407 & $8 / 20 / 2003$ & $17: 55$ & 20.17 & 0.285 \\
\hline Tst2-202-409 & $8 / 20 / 2003$ & $20: 45$ & 20.29 & 0.281 \\
\hline Tst2-202-413 & $8 / 21 / 2003$ & $9: 19$ & 20.82 & 0.275 \\
\hline Tst2-202-415 & $8 / 21 / 2003$ & $15: 00$ & 21.05 & 0.272 \\
\hline Tst2-202-419 & $8 / 22 / 2003$ & $11: 09$ & 21.89 & 0.267 \\
\hline Tst2-202-421 & $8 / 23 / 2003$ & $10: 37$ & 22.87 & 0.256 \\
\hline Tst2-202-425 & $8 / 25 / 2003$ & $8: 43$ & 24.79 & 0.225 \\
\hline Tst2-202-427 & $8 / 25 / 2003$ & $15: 35$ & 25.08 & 0.216 \\
\hline Tst2-202-431 & $8 / 26 / 2003$ & $9: 41$ & 25.83 & 0.209 \\
\hline Tst2-202-433 & $8 / 26 / 2003$ & $15: 42$ & 26.08 & 0.203 \\
\hline Tst2-202-439 & $8 / 27 / 2003$ & $14: 32$ & 27.03 & 0.190 \\
\hline Tst2-202-443 & $8 / 28 / 2003$ & $10: 12$ & 27.85 & 0.171 \\
\hline Tst2-202-445 & $8 / 28 / 2003$ & $15: 43$ & 28.08 & 0.156 \\
\hline Tst2-202-449 & $8 / 29 / 2003$ & $15: 20$ & 29.07 & 0.153 \\
\hline Tst2-202-455 & $9 / 3 / 2003$ & $12: 35$ & 33.95 & 0.124 \\
\hline Tst2-202-459 & $9 / 4 / 2003$ & $14: 38$ & 35.04 & 0.121 \\
\hline Tst2-202-461 & $9 / 8 / 2003$ & $13: 48$ & 39.00 & 0.103 \\
\hline Tst2-202-471 & $9 / 11 / 2003$ & $11: 25$ & 41.90 & 0.095 \\
\hline Tst2-202-483 & 9/22/2003 & $15: 26$ & 53.07 & 0.058 \\
\hline Tst2-202-491 & $10 / 20 / 2003$ & $10: 10$ & 80.85 & 0.022 \\
\hline
\end{tabular}

Table A-14: HPLC data from test 2, well 203

\begin{tabular}{|c|c|c|c|c|}
\hline Sample Name & Date & Time & $\begin{array}{c}\text { Time elapsed } \\
\text { (days) }\end{array}$ & 2,4-DFBA (mg/L) \\
\hline Tst2-203-005 & $8 / 7 / 2003$ & $22: 35$ & 7.37 & 0.629 \\
\hline Tst2-203-006 & $8 / 8 / 2003$ & $7: 14$ & 7.73 & 0.580 \\
\hline Tst2-203-010 & $8 / 8 / 2003$ & $12: 45$ & 7.96 & 0.532 \\
\hline Tst2-203-011 & $8 / 8 / 2003$ & $17: 53$ & 8.17 & 0.575 \\
\hline Tst2-203-013 & $8 / 8 / 2003$ & $21: 17$ & 8.31 & 0.571 \\
\hline Tst2-203-014 & $8 / 8 / 2003$ & $22: 44$ & 8.37 & 0.547 \\
\hline Tst2-203-015 & $8 / 9 / 2003$ & $6: 00$ & 8.68 & 0.517 \\
\hline Tst2-203-016 & $8 / 9 / 2003$ & $8: 55$ & 8.80 & 0.462 \\
\hline Tst2-203-018 & $8 / 9 / 2003$ & $18: 17$ & 9.19 & 0.437 \\
\hline Tst2-203-019 & $8 / 9 / 2003$ & $20: 36$ & 9.29 & 0.441 \\
\hline Tst2-203-020 & $8 / 9 / 2003$ & $23: 00$ & 9.39 & 0.424 \\
\hline Tst2-203-022 & $8 / 10 / 2003$ & $5: 50$ & 9.67 & 0.417 \\
\hline Tst2-203-023 & $8 / 10 / 2003$ & $8: 50$ & 9.80 & 0.340 \\
\hline
\end{tabular}


Table A-14: Continued

\begin{tabular}{|c|c|c|c|c|}
\hline Sample Name & Date & Time & $\begin{array}{c}\text { Time elapsed } \\
\text { (days) }\end{array}$ & 2,4-DFBA (mg/L) \\
\hline Tst2-203-024 & $8 / 10 / 2003$ & $12: 14$ & 9.94 & 0.355 \\
\hline Tst2-203-025 & $8 / 10 / 2003$ & $19: 07$ & 10.22 & 0.359 \\
\hline Tst2-203-026 & $8 / 10 / 2003$ & 22:55 & 10.38 & 0.370 \\
\hline Tst2-203-028 & $8 / 11 / 2003$ & 9:35 & 10.83 & 0.389 \\
\hline Tst2-203-029 & $8 / 11 / 2003$ & $14: 40$ & 11.04 & 0.453 \\
\hline Tst2-203-033 & $8 / 11 / 2003$ & $20: 21$ & 11.28 & 0.344 \\
\hline Tst2-203-039 & $8 / 12 / 2003$ & $6: 35$ & 11.70 & 0.328 \\
\hline Tst2-203-040 & $8 / 12 / 2003$ & $10: 20$ & 11.86 & 0.236 \\
\hline Tst2-203-041 & $8 / 12 / 2003$ & $13: 00$ & 11.97 & 0.312 \\
\hline Tst2-203-051 & $8 / 13 / 2003$ & $5: 58$ & 12.68 & 0.207 \\
\hline Tst2-203-053 & $8 / 13 / 2003$ & $11: 11$ & 12.89 & 0.235 \\
\hline Tst2-203-063 & $8 / 14 / 2003$ & $6: 06$ & 13.68 & 0.194 \\
\hline Tst2-203-064 & $8 / 14 / 2003$ & 9:11 & 13.81 & 0.200 \\
\hline Tst2-203-065 & $8 / 14 / 2003$ & 11:01 & 13.89 & 0.187 \\
\hline Tst2-203-075 & $8 / 15 / 2003$ & $6: 17$ & 14.69 & 0.177 \\
\hline Tst2-203-098 & $8 / 16 / 2003$ & $9: 27$ & 15.82 & 0.137 \\
\hline Tst2-203-099 & $8 / 16 / 2003$ & $11: 07$ & 15.89 & 0.131 \\
\hline Tst2-203-103 & $8 / 16 / 2003$ & $20: 15$ & 16.27 & 0.237 \\
\hline Tst2-203-104 & $8 / 16 / 2003$ & $22: 39$ & 16.37 & 0.137 \\
\hline Tst2-203-108 & $8 / 17 / 2003$ & $17: 44$ & 17.17 & 0.172 \\
\hline Tst2-203-109 & $8 / 17 / 2003$ & $20: 27$ & 17.28 & 0.124 \\
\hline Tst2-203-111 & $8 / 18 / 2003$ & $6: 15$ & 17.69 & 0.132 \\
\hline Tst2-203-112 & $8 / 18 / 2003$ & 9:56 & 17.84 & 0.140 \\
\hline Tst2-203-113 & $8 / 18 / 2003$ & 13:06 & 17.97 & 0.090 \\
\hline Tst2-203-114 & $8 / 18 / 2003$ & $19: 40$ & 18.25 & 0.088 \\
\hline Tst2-203-115 & $8 / 18 / 2003$ & $21: 01$ & 18.30 & 0.079 \\
\hline Tst2-203-116 & $8 / 18 / 2003$ & $22: 55$ & 18.38 & 0.082 \\
\hline Tst2-203-117 & $8 / 19 / 2003$ & $8: 50$ & 18.80 & 0.124 \\
\hline Tst2-203-118 & $8 / 19 / 2003$ & 11:05 & 18.89 & 0.123 \\
\hline Tst2-203-119 & $8 / 19 / 2003$ & $17: 54$ & 19.17 & 0.063 \\
\hline Tst2-203-120 & 8/19/2003 & $20: 38$ & 19.29 & 0.125 \\
\hline Tst2-203-121 & $8 / 20 / 2003$ & $10: 10$ & 19.85 & 0.145 \\
\hline Tst2-203-122 & $8 / 20 / 2003$ & $11: 50$ & 19.92 & 0.111 \\
\hline Tst2-203-124 & $8 / 20 / 2003$ & $20: 43$ & 20.29 & 0.113 \\
\hline Tst2-203-125 & $8 / 21 / 2003$ & 9:25 & 20.82 & 0.095 \\
\hline Tst2-203-126 & $8 / 21 / 2003$ & $14: 55$ & 21.05 & 0.087 \\
\hline Tst2-203-139 & $8 / 26 / 2003$ & $9: 37$ & 25.83 & 0.079 \\
\hline Tst2-203-140 & $8 / 26 / 2003$ & $15: 39$ & 26.08 & 0.070 \\
\hline Tst2-203-160 & $9 / 2 / 2003$ & $10: 17$ & 32.86 & 0.024 \\
\hline Tst2-203-163 & $9 / 8 / 2003$ & $13: 45$ & 39.00 & 0.049 \\
\hline Tst2-203-164 & 9/9/2003 & $11: 20$ & 39.90 & 0.051 \\
\hline Tst2-203-165 & 9/10/2003 & $11: 20$ & 40.90 & 0.045 \\
\hline Tst2-203-166 & $9 / 11 / 2003$ & $11: 27$ & 41.90 & 0.006 \\
\hline
\end{tabular}


Table A-14: Continued

\begin{tabular}{|c|c|c|c|c|}
\hline Sample Name & Date & Time & $\begin{array}{c}\text { Time elapsed } \\
\text { (days) }\end{array}$ & 2,4-DFBA (mg/L) \\
\hline Tst2-203-167 & $9 / 15 / 2003$ & $10: 52$ & 45.88 & 0.083 \\
\hline Tst2-203-169 & $9 / 18 / 2003$ & $10: 50$ & 48.88 & 0.055 \\
\hline Tst2-203-170 & $9 / 22 / 2003$ & $15: 20$ & 53.07 & 0.074 \\
\hline Tst2-203-171 & 9/25/2003 & $15: 00$ & 56.05 & 0.047 \\
\hline
\end{tabular}

Table A-15: HPLC data from test 2, well 210

\begin{tabular}{|c|c|c|c|c|}
\hline Sample Name & Date & Time & $\begin{array}{c}\text { Time elapsed } \\
\text { (days) }\end{array}$ & 2,4-DFBA (mg/L) \\
\hline Tst2-210-001 & $8 / 1 / 2003$ & $11: 02$ & 0.89 & $<0.016$ \\
\hline Tst2-210-003 & $8 / 1 / 2003$ & $14: 07$ & 1.02 & $<0.016$ \\
\hline Tst2-210-007 & $8 / 1 / 2003$ & $17: 00$ & 1.14 & $<0.016$ \\
\hline Tst2-210-009 & $8 / 1 / 2003$ & $20: 39$ & 1.29 & $<0.016$ \\
\hline Tst2-210-013 & $8 / 1 / 2003$ & $23: 21$ & 1.40 & $<0.016$ \\
\hline Tst2-210-015 & $8 / 2 / 2003$ & $5: 54$ & 1.67 & $<0.016$ \\
\hline Tst2-210-019 & $8 / 2 / 2003$ & $8: 52$ & 1.80 & $<0.016$ \\
\hline Tst2-210-021 & $8 / 2 / 2003$ & $12: 06$ & 1.93 & $<0.016$ \\
\hline Tst2-210-025 & $8 / 2 / 2003$ & $17: 57$ & 2.18 & $<0.016$ \\
\hline Tst2-210-027 & $8 / 2 / 2003$ & $21: 22$ & 2.32 & $<0.016$ \\
\hline Tst2-210-031 & $8 / 2 / 2003$ & $23: 34$ & 2.41 & $<0.016$ \\
\hline Tst2-210-033 & $8 / 2 / 2003$ & $5: 56$ & 1.67 & $<0.016$ \\
\hline Tst2-210-037 & $8 / 3 / 2003$ & $8: 54$ & 2.80 & $<0.016$ \\
\hline Tst2-210-039 & $8 / 3 / 2003$ & $12: 35$ & 2.95 & $<0.016$ \\
\hline Tst2-210-043 & $8 / 3 / 2003$ & $20: 50$ & 3.30 & $<0.016$ \\
\hline Tst2-210-045 & $8 / 3 / 2003$ & $23: 11$ & 3.39 & $<0.016$ \\
\hline Tst2-210-061 & $8 / 3 / 2003$ & $18: 00$ & 3.18 & $<0.016$ \\
\hline
\end{tabular}

Table A-16: HPLC data from test 2, well 211

\begin{tabular}{|c|c|c|c|c|}
\hline Sample Name & Date & Time & $\begin{array}{c}\text { Time elapsed } \\
\text { (days) }\end{array}$ & 2,4-DFBA (mg/L) \\
\hline Tst2-211-001 & $8 / 1 / 2003$ & $11: 16$ & 0.90 & $<0.016$ \\
\hline Tst2-211-003 & $8 / 1 / 2003$ & $14: 16$ & 1.02 & $<0.016$ \\
\hline Tst2-211-007 & $8 / 1 / 2003$ & $17: 13$ & 1.14 & $<0.016$ \\
\hline Tst2-211-009 & $8 / 1 / 2003$ & $20: 31$ & 1.28 & $<0.016$ \\
\hline Tst2-211-013 & $8 / 1 / 2003$ & $23: 15$ & 1.40 & $<0.016$ \\
\hline Tst2-211-015 & $8 / 2 / 2003$ & $6: 04$ & 1.68 & $<0.016$ \\
\hline Tst2-211-019 & $8 / 2 / 2003$ & $9: 02$ & 1.80 & $<0.016$ \\
\hline Tst2-211-021 & $8 / 2 / 2003$ & $12: 18$ & 1.94 & $<0.016$ \\
\hline Tst2-211-025 & $8 / 2 / 2003$ & $17: 50$ & 2.17 & $<0.016$ \\
\hline Tst2-211-027 & $8 / 2 / 2003$ & $21: 17$ & 2.31 & $<0.016$ \\
\hline Tst2-211-031 & $8 / 2 / 2003$ & $23: 29$ & 2.41 & $<0.016$ \\
\hline
\end{tabular}


Table A-16: Continued

\begin{tabular}{|c|c|c|c|c|}
\hline Sample Name & Date & Time & $\begin{array}{c}\text { Time elapsed } \\
\text { (days) }\end{array}$ & 2,4-DFBA (mg/L) \\
\hline Tst2-211-033 & $8 / 3 / 2003$ & $6: 08$ & 2.68 & $<0.016$ \\
\hline Tst2-211-037 & $8 / 3 / 2003$ & 9:09 & 2.81 & $<0.016$ \\
\hline Tst2-211-039 & 8/3/2003 & $12: 31$ & 2.95 & $<0.016$ \\
\hline Tst2-211-043 & $8 / 3 / 2003$ & $17: 40$ & 3.16 & $<0.016$ \\
\hline Tst2-211-045 & $8 / 3 / 2003$ & $20: 43$ & 3.29 & $<0.016$ \\
\hline Tst2-211-049 & $8 / 3 / 2003$ & 23:09 & 3.39 & $<0.016$ \\
\hline Tst2-211-051 & $8 / 4 / 2003$ & $6: 30$ & 3.70 & $<0.016$ \\
\hline Tst2-211-055 & $8 / 4 / 2003$ & $9: 14$ & 3.81 & $<0.016$ \\
\hline Tst2-211-057 & $8 / 4 / 2003$ & $11: 18$ & 3.90 & $<0.016$ \\
\hline Tst2-211-061 & $8 / 4 / 2003$ & $20: 42$ & 4.29 & $<0.016$ \\
\hline Tst2-211-063 & $8 / 4 / 2003$ & $23: 10$ & 4.39 & $<0.016$ \\
\hline Tst2-211-067 & $8 / 5 / 2003$ & $6: 35$ & 4.70 & $<0.016$ \\
\hline Tst2-211-069 & $8 / 5 / 2003$ & $9: 10$ & 4.81 & $<0.016$ \\
\hline Tst2-211-073 & $8 / 5 / 2003$ & $18: 06$ & 5.18 & $<0.016$ \\
\hline Tst2-211-075 & $8 / 5 / 2003$ & $22: 00$ & 5.34 & $<0.016$ \\
\hline Tst2-211-079 & $8 / 5 / 2003$ & 23:44 & 5.42 & $<0.016$ \\
\hline Tst2-211-081 & $8 / 6 / 2003$ & $6: 45$ & 5.71 & $<0.016$ \\
\hline Tst2-211-085 & $8 / 6 / 2003$ & $10: 10$ & 5.85 & $<0.016$ \\
\hline Tst2-211-087 & $8 / 6 / 2003$ & $13: 33$ & 5.99 & $<0.016$ \\
\hline Tst2-211-091 & 8/6/2003 & $18: 29$ & 6.20 & $<0.016$ \\
\hline Tst2-211-094 & $8 / 6 / 2003$ & $21: 48$ & 6.34 & $<0.016$ \\
\hline Tst2-211-097 & $8 / 6 / 2003$ & $23: 43$ & 6.42 & $<0.016$ \\
\hline Tst2-211-103 & $8 / 7 / 2003$ & $12: 58$ & 6.97 & 0.010 \\
\hline Tst2-211-105 & 8/7/2003 & $18: 41$ & 7.21 & 0.012 \\
\hline Tst2-211-109 & $8 / 7 / 2003$ & $20: 58$ & 7.30 & 0.020 \\
\hline Tst2-211-111 & $8 / 7 / 2003$ & $22: 44$ & 7.37 & 0.023 \\
\hline Tst2-211-115 & $8 / 8 / 2003$ & $6: 17$ & 7.69 & 0.026 \\
\hline Tst2-211-117 & $8 / 8 / 2003$ & $9: 25$ & 7.82 & 0.035 \\
\hline Tst2-211-121 & $8 / 8 / 2003$ & $12: 15$ & 7.94 & 0.044 \\
\hline Tst2-211-123 & 8/8/2003 & $18: 08$ & 8.18 & 0.037 \\
\hline Tst2-211-127 & 8/8/2003 & $20: 07$ & 8.27 & 0.057 \\
\hline Tst2-211-129 & 8/8/2003 & $21: 25$ & 8.32 & 0.056 \\
\hline Tst2-211-133 & $8 / 8 / 2003$ & $22: 54$ & 8.38 & 0.071 \\
\hline Tst2-211-135 & 8/9/2003 & $7: 15$ & 8.73 & 0.096 \\
\hline Tst2-211-139 & $8 / 9 / 2003$ & $9: 45$ & 8.83 & 0.099 \\
\hline Tst2-211-141 & $8 / 9 / 2003$ & $12: 35$ & 8.95 & 0.101 \\
\hline Tst2-211-145 & $8 / 9 / 2003$ & $18: 40$ & 9.20 & 0.101 \\
\hline Tst2-211-147 & $8 / 9 / 2003$ & $21: 00$ & 9.30 & 0.107 \\
\hline Tst2-211-151 & 8/9/2003 & $23: 20$ & 9.40 & 0.119 \\
\hline Tst2-211-153 & $8 / 10 / 2003$ & $6: 50$ & 9.71 & 0.120 \\
\hline Tst2-211-157 & $8 / 10 / 2003$ & $9: 40$ & 9.83 & 0.123 \\
\hline Tst2-211-159 & $8 / 10 / 2003$ & $12: 07$ & 9.93 & 0.121 \\
\hline Tst2-211-163 & $8 / 10 / 2003$ & 19:30 & 10.24 & 0.146 \\
\hline
\end{tabular}


Table A-16: Continued

\begin{tabular}{|c|c|c|c|c|}
\hline Sample Name & Date & Time & $\begin{array}{c}\text { Time elapsed } \\
\text { (days) }\end{array}$ & 2,4-DFBA (mg/L) \\
\hline Tst2-211-165 & $8 / 10 / 2003$ & $23: 18$ & 10.40 & 0.153 \\
\hline Tst2-211-169 & $8 / 11 / 2003$ & $7: 10$ & 10.73 & 0.167 \\
\hline Tst2-211-171 & $8 / 11 / 2003$ & $10: 50$ & 10.88 & 0.164 \\
\hline Tst2-211-175 & $8 / 11 / 2003$ & $18: 28$ & 11.20 & 0.178 \\
\hline Tst2-211-177 & $8 / 11 / 2003$ & $21: 20$ & 11.32 & 0.173 \\
\hline Tst2-211-181 & $8 / 11 / 2003$ & $23: 19$ & 11.40 & 0.189 \\
\hline Tst2-211-183 & 8/12/2003 & $6: 55$ & 11.72 & 0.184 \\
\hline Tst2-211-187 & $8 / 12 / 2003$ & $10: 40$ & 11.87 & 0.185 \\
\hline Tst2-211-191 & $8 / 12 / 2003$ & $19: 01$ & 12.22 & 0.191 \\
\hline Tst2-211-193 & $8 / 12 / 2003$ & $21: 32$ & 12.32 & 0.194 \\
\hline Tst2-211-197 & $8 / 13 / 2003$ & $6: 15$ & 12.69 & 0.177 \\
\hline Tst2-211-199 & $8 / 13 / 2003$ & 9:09 & 12.81 & 0.193 \\
\hline Tst2-211-201 & $8 / 13 / 2003$ & $10: 54$ & 12.88 & 0.205 \\
\hline Tst2-211-205 & $8 / 13 / 2003$ & $18: 14$ & 13.19 & 0.190 \\
\hline Tst2-211-209 & $8 / 13 / 2003$ & $21: 19$ & 13.32 & 0.197 \\
\hline Tst2-211-211 & $8 / 13 / 2003$ & $23: 09$ & 13.39 & 0.188 \\
\hline Tst2-211-213 & $8 / 14 / 2003$ & $6: 20$ & 13.69 & 0.201 \\
\hline Tst2-211-217 & $8 / 14 / 2003$ & 9:08 & 13.81 & 0.185 \\
\hline Tst2-211-221 & $8 / 14 / 2003$ & $11: 13$ & 13.89 & 0.193 \\
\hline Tst2-211-225 & $8 / 14 / 2003$ & 21:06 & 14.31 & 0.231 \\
\hline Tst2-211-231 & $8 / 15 / 2003$ & $6: 36$ & 14.70 & 0.212 \\
\hline Tst2-211-235 & $8 / 15 / 2003$ & $8: 25$ & 14.78 & 0.247 \\
\hline Tst2-211-237 & $8 / 15 / 2003$ & $12: 45$ & 14.96 & 0.229 \\
\hline Tst2-211-241 & $8 / 15 / 2003$ & $18: 10$ & 15.18 & 0.234 \\
\hline Tst2-211-245 & $8 / 15 / 2003$ & $20: 35$ & 15.28 & 0.241 \\
\hline Tst2-211-247 & $8 / 15 / 2003$ & $23: 13$ & 15.39 & 0.255 \\
\hline Tst2-211-249 & $8 / 16 / 2003$ & $7: 08$ & 15.72 & 0.225 \\
\hline Tst2-211-253 & $8 / 16 / 2003$ & $9: 38$ & 15.83 & 0.233 \\
\hline Tst2-211-255 & $8 / 16 / 2003$ & $11: 19$ & 15.90 & 0.241 \\
\hline Tst2-211-259 & $8 / 16 / 2003$ & $17: 59$ & 16.18 & 0.271 \\
\hline Tst2-211-261 & $8 / 16 / 2003$ & 21:17 & 16.31 & 0.272 \\
\hline Tst2-211-265 & $8 / 16 / 2003$ & $22: 55$ & 16.38 & 0.272 \\
\hline Tst2-211-267 & $8 / 17 / 2003$ & $7: 20$ & 16.73 & 0.263 \\
\hline Tst2-211-271 & $8 / 17 / 2003$ & $9: 05$ & 16.81 & 0.278 \\
\hline Tst2-211-273 & $8 / 17 / 2003$ & $11: 43$ & 16.92 & 0.297 \\
\hline Tst2-211-277 & $8 / 17 / 2003$ & $18: 16$ & 17.19 & 0.300 \\
\hline Tst2-211-281 & $8 / 17 / 2003$ & $20: 51$ & 17.30 & 0.291 \\
\hline Tst2-211-282 & $8 / 17 / 2003$ & $23: 15$ & 17.40 & 0.266 \\
\hline Tst2-211-285 & $8 / 18 / 2003$ & $6: 40$ & 17.70 & 0.290 \\
\hline Tst2-211-289 & $8 / 18 / 2003$ & $10: 15$ & 17.85 & 0.278 \\
\hline Tst2-211-293 & $8 / 18 / 2003$ & $13: 25$ & 17.99 & 0.288 \\
\hline Tst2-211-295 & $8 / 18 / 2003$ & $19: 55$ & 18.26 & 0.307 \\
\hline Tst2-211-297 & $8 / 18 / 2003$ & $21: 11$ & 18.31 & 0.294 \\
\hline
\end{tabular}


Table A-16: Continued

\begin{tabular}{|c|c|c|c|c|}
\hline Sample Name & Date & Time & $\begin{array}{c}\text { Time elapsed } \\
\text { (days) }\end{array}$ & 2,4-DFBA (mg/L) \\
\hline Tst2-211-301 & $8 / 18 / 2003$ & 23:07 & 18.39 & 0.295 \\
\hline Tst2-211-303 & $8 / 19 / 2003$ & 9:19 & 18.82 & 0.309 \\
\hline Tst2-211-307 & $8 / 19 / 2003$ & $11: 30$ & 18.91 & 0.291 \\
\hline Tst2-211-309 & $8 / 19 / 2003$ & $18: 13$ & 19.19 & 0.299 \\
\hline Tst2-211-313 & $8 / 19 / 2003$ & $21: 03$ & 19.30 & 0.307 \\
\hline Tst2-211-315 & $8 / 20 / 2003$ & $10: 33$ & 19.87 & 0.293 \\
\hline Tst2-211-319 & $8 / 20 / 2003$ & $12: 13$ & 19.94 & 0.300 \\
\hline Tst2-211-321 & $8 / 20 / 2003$ & 18:16 & 20.19 & 0.304 \\
\hline Tst2-211-325 & $8 / 20 / 2003$ & 21:07 & 20.31 & 0.272 \\
\hline Tst2-211-327 & $8 / 21 / 2003$ & 9:49 & 20.84 & 0.272 \\
\hline Tst2-211-331 & $8 / 21 / 2003$ & $15: 20$ & 21.07 & 0.267 \\
\hline Tst2-211-333 & $8 / 22 / 2003$ & $11: 32$ & 21.91 & 0.260 \\
\hline Tst2-211-337 & $8 / 23 / 2003$ & $11: 00$ & 22.89 & 0.261 \\
\hline Tst2-211-339 & $8 / 25 / 2003$ & $9: 15$ & 24.81 & 0.254 \\
\hline Tst2-211-343 & $8 / 25 / 2003$ & $15: 53$ & 25.09 & 0.234 \\
\hline Tst2-211-345 & $8 / 26 / 2003$ & $9: 58$ & 25.84 & 0.236 \\
\hline Tst2-211-349 & $8 / 26 / 2003$ & $15: 37$ & 26.08 & 0.218 \\
\hline Tst2-211-351 & $8 / 27 / 2003$ & $9: 25$ & 26.82 & 0.225 \\
\hline Tst2-211-355 & $8 / 27 / 2003$ & $14: 51$ & 27.05 & 0.234 \\
\hline Tst2-211-357 & $8 / 28 / 2003$ & $10: 35$ & 27.87 & 0.210 \\
\hline Tst2-211-367 & $8 / 29 / 2003$ & $15: 40$ & 29.08 & 0.203 \\
\hline Tst2-211-369 & 9/2/2003 & $11: 05$ & 32.89 & 0.186 \\
\hline Tst2-211-373 & $9 / 3 / 2003$ & $12: 52$ & 33.96 & 0.171 \\
\hline Tst2-211-375 & $9 / 4 / 2003$ & 15:05 & 35.06 & 0.166 \\
\hline Tst2-211-379 & 9/8/2003 & $14: 18$ & 39.02 & 0.142 \\
\hline Tst2-211-381 & 9/9/2003 & $12: 08$ & 39.93 & 0.135 \\
\hline Tst2-211-385 & 9/10/2003 & $11: 50$ & 40.92 & 0.122 \\
\hline Tst2-211-387 & 9/11/2003 & $12: 00$ & 41.93 & 0.129 \\
\hline Tst2-211-393 & 9/16/2003 & $8: 59$ & 46.80 & 0.091 \\
\hline Tst2-211-397 & $9 / 18 / 2003$ & $11: 20$ & 48.90 & 0.079 \\
\hline Tst2-211-399 & 9/22/2003 & $15: 50$ & 53.09 & 0.075 \\
\hline Tst2-211-403 & $9 / 25 / 2003$ & $15: 25$ & 56.07 & 0.069 \\
\hline Tst2-211-405 & $10 / 20 / 2003$ & $10: 35$ & 80.87 & 0.035 \\
\hline
\end{tabular}

Table A-17: HPLC data from test 2, well 212

\begin{tabular}{|c|c|c|c|c|}
\hline Sample Name & Date & Time & $\begin{array}{c}\text { Time elapsed } \\
\text { (days) }\end{array}$ & 2,4-DFBA (mg/L) \\
\hline Tst2-212-001 & $8 / 1 / 2003$ & $13: 31$ & 0.99 & $<0.016$ \\
\hline Tst2-212-003 & $8 / 1 / 2003$ & $20: 20$ & 1.27 & $<0.016$ \\
\hline Tst2-212-007 & $8 / 2 / 2003$ & $7: 16$ & 1.73 & $<0.016$ \\
\hline Tst2-212-009 & $8 / 2 / 2003$ & $13: 10$ & 1.98 & $<0.016$ \\
\hline Tst2-212-013 & $8 / 2 / 2003$ & $18: 26$ & 2.20 & $<0.016$ \\
\hline
\end{tabular}


Table A-17: Continued

\begin{tabular}{|c|c|c|c|c|}
\hline Sample Name & Date & Time & $\begin{array}{c}\text { Time elapsed } \\
\text { (days) }\end{array}$ & 2,4-DFBA (mg/L) \\
\hline Tst2-212-015 & $8 / 2 / 2003$ & 23:04 & 2.39 & $<0.016$ \\
\hline Tst2-212-019 & $8 / 3 / 2003$ & 7:01 & 2.72 & $<0.016$ \\
\hline Tst2-212-021 & $8 / 3 / 2003$ & $11: 55$ & 2.92 & $<0.016$ \\
\hline Tst2-212-027 & $8 / 4 / 2003$ & $7: 20$ & 3.73 & $<0.016$ \\
\hline Tst2-212-031 & $8 / 4 / 2003$ & $10: 17$ & 3.86 & $<0.016$ \\
\hline Tst2-212-033 & $8 / 4 / 2003$ & 23:44 & 4.42 & $<0.016$ \\
\hline Tst2-212-039 & $8 / 5 / 2003$ & $10: 22$ & 4.86 & $<0.016$ \\
\hline Tst2-212-043 & $8 / 6 / 2003$ & $10: 40$ & 5.87 & $<0.016$ \\
\hline Tst2-212-045 & $8 / 6 / 2003$ & $19: 43$ & 6.25 & $<0.016$ \\
\hline Tst2-212-049 & $8 / 7 / 2003$ & 23:58 & 7.43 & $<0.016$ \\
\hline Tst2-212-051 & $8 / 7 / 2003$ & $7: 10$ & 6.73 & $<0.016$ \\
\hline Tst2-212-055 & $8 / 7 / 2003$ & 19:10 & 7.23 & $<0.016$ \\
\hline Tst2-212-057 & $8 / 8 / 2003$ & $7: 43$ & 7.75 & $<0.016$ \\
\hline Tst2-212-061 & 8/8/2003 & $11: 22$ & 7.90 & $<0.016$ \\
\hline Tst2-212-065 & 8/8/2003 & $18: 12$ & 8.19 & $<0.016$ \\
\hline Tst2-212-067 & $8 / 9 / 2003$ & $7: 48$ & 8.75 & $<0.016$ \\
\hline Tst2-212-069 & 8/9/2003 & $11: 15$ & 8.90 & $<0.016$ \\
\hline Tst2-212-073 & $8 / 9 / 2003$ & $20: 45$ & 9.29 & $<0.016$ \\
\hline Tst2-212-079 & $8 / 10 / 2003$ & $11: 06$ & 9.89 & $<0.016$ \\
\hline Tst2-212-081 & $8 / 10 / 2003$ & $20: 40$ & 10.29 & $<0.016$ \\
\hline Tst2-212-085 & $8 / 11 / 2003$ & $7: 25$ & 10.74 & $<0.016$ \\
\hline Tst2-212-087 & $8 / 11 / 2003$ & $12: 30$ & 10.95 & $<0.016$ \\
\hline Tst2-212-091 & $8 / 11 / 2003$ & $21: 48$ & 11.34 & $<0.016$ \\
\hline Tst2-212-093 & $8 / 12 / 2003$ & $7: 10$ & 11.73 & $<0.016$ \\
\hline Tst2-212-097 & $8 / 12 / 2003$ & $13: 30$ & 11.99 & $<0.016$ \\
\hline Tst2-212-101 & $8 / 12 / 2003$ & $22: 03$ & 12.35 & $<0.016$ \\
\hline Tst2-212-103 & $8 / 13 / 2003$ & $6: 08$ & 12.68 & $<0.016$ \\
\hline Tst2-212-105 & $8 / 13 / 2003$ & $11: 07$ & 12.89 & $<0.016$ \\
\hline Tst2-212-109 & $8 / 13 / 2003$ & $21: 29$ & 13.32 & $<0.016$ \\
\hline Tst2-212-111 & $8 / 14 / 2003$ & $9: 18$ & 13.81 & $<0.016$ \\
\hline Tst2-212-115 & $8 / 14 / 2003$ & 21:20 & 14.32 & $<0.016$ \\
\hline Tst2-212-117 & $8 / 15 / 2003$ & $8: 47$ & 14.79 & $<0.016$ \\
\hline Tst2-212-121 & $8 / 15 / 2003$ & 21:07 & 15.31 & $<0.016$ \\
\hline Tst2-212-123 & $8 / 16 / 2003$ & $9: 41$ & 15.83 & $<0.016$ \\
\hline Tst2-212-127 & $8 / 16 / 2003$ & $21: 27$ & 16.32 & $<0.016$ \\
\hline Tst2-212-129 & $8 / 17 / 2003$ & $7: 10$ & 16.73 & $<0.016$ \\
\hline Tst2-212-133 & $8 / 17 / 2003$ & $11: 48$ & 16.92 & $<0.016$ \\
\hline Tst2-212-139 & $8 / 18 / 2003$ & $6: 50$ & 17.71 & $<0.016$ \\
\hline Tst2-212-141 & $8 / 18 / 2003$ & $10: 46$ & 17.88 & $<0.016$ \\
\hline Tst2-212-145 & $8 / 18 / 2003$ & $20: 50$ & 18.30 & $<0.016$ \\
\hline Tst2-212-147 & $8 / 19 / 2003$ & $10: 12$ & 18.85 & $<0.016$ \\
\hline Tst2-212-151 & $8 / 19 / 2003$ & $14: 10$ & 19.02 & $<0.016$ \\
\hline Tst2-212-153 & $8 / 19 / 2003$ & $18: 54$ & 19.21 & $<0.016$ \\
\hline
\end{tabular}


Table A-17: Continued

\begin{tabular}{|c|c|c|c|c|}
\hline Sample Name & Date & Time & $\begin{array}{c}\text { Time elapsed } \\
\text { (days) }\end{array}$ & 2,4-DFBA (mg/L) \\
\hline Tst2-212-157 & $8 / 20 / 2003$ & $9: 15$ & 19.81 & $<0.016$ \\
\hline Tst2-212-163 & $8 / 20 / 2003$ & $0: 00$ & 19.43 & $<0.016$ \\
\hline Tst2-212-165 & $8 / 21 / 2003$ & $10: 00$ & 20.84 & $<0.016$ \\
\hline Tst2-212-169 & $8 / 21 / 2003$ & $15: 30$ & 21.07 & $<0.016$ \\
\hline Tst2-212-171 & $8 / 22 / 2003$ & $9: 31$ & 21.82 & $<0.016$ \\
\hline Tst2-212-177 & $8 / 25 / 2003$ & $9: 30$ & 24.82 & $<0.016$ \\
\hline Tst2-212-181 & $8 / 25 / 2003$ & $16: 10$ & 25.10 & $<0.016$ \\
\hline Tst2-212-183 & $8 / 26 / 2003$ & $10: 14$ & 25.85 & $<0.016$ \\
\hline Tst2-212-187 & $8 / 26 / 2003$ & $16: 08$ & 26.10 & $<0.016$ \\
\hline Tst2-212-189 & $8 / 27 / 2003$ & $9: 35$ & 26.83 & $<0.016$ \\
\hline Tst2-212-193 & $8 / 27 / 2003$ & $15: 00$ & 27.05 & $<0.016$ \\
\hline Tst2-212-195 & $8 / 28 / 2003$ & $10: 53$ & 27.88 & $<0.016$ \\
\hline Tst2-212-201 & $8 / 29 / 2003$ & $14: 55$ & 29.05 & $<0.016$ \\
\hline Tst2-212-205 & $9 / 2 / 2003$ & $11: 10$ & 32.89 & 0.002 \\
\hline Tst2-212-211 & $9 / 4 / 2003$ & $15: 20$ & 35.07 & 0.005 \\
\hline Tst2-212-213 & $9 / 8 / 2003$ & $14: 24$ & 39.03 & 0.005 \\
\hline Tst2-212-225 & $9 / 15 / 2003$ & $11: 30$ & 45.91 & 0.019 \\
\hline Tst2-212-231 & $9 / 18 / 2003$ & $11: 34$ & 48.91 & 0.013 \\
\hline Tst2-212-235 & $9 / 22 / 2003$ & $16: 15$ & 53.10 & 0.024 \\
\hline Tst2-212-239 & $9 / 25 / 2003$ & $15: 36$ & 56.08 & 0.026 \\
\hline Tst2-212-242 & $10 / 20 / 2003$ & $10: 38$ & 80.87 & 0.011 \\
\hline
\end{tabular}

Table A-18: HPLC data from test 2, lysimeter 198114

\begin{tabular}{|c|c|c|c|c|}
\hline Sample Name & Date & Time & $\begin{array}{c}\text { Time elapsed } \\
\text { (days) }\end{array}$ & 2,4-DFBA (mg/L) \\
\hline Tst2-198114-001 & $8 / 1 / 2003$ & $11: 59$ & 0.93 & 0.011 \\
\hline Tst2-198114-008 & $8 / 2 / 2003$ & $6: 19$ & 1.69 & 0.015 \\
\hline Tst2-198114-009 & $8 / 2 / 2003$ & $12: 32$ & 1.95 & 0.016 \\
\hline Tst2-198114-011 & $8 / 2 / 2003$ & $20: 33$ & 2.28 & 0.014 \\
\hline Tst2-198114-013 & $8 / 3 / 2003$ & $6: 22$ & 2.69 & $<0.016$ \\
\hline Tst2-198114-017 & $8 / 3 / 2003$ & $12: 10$ & 2.93 & $<0.016$ \\
\hline Tst2-198114-019 & $8 / 3 / 2003$ & $20: 09$ & 3.27 & $<0.016$ \\
\hline Tst2-198114-023 & $8 / 4 / 2003$ & $6: 40$ & 3.70 & $<0.016$ \\
\hline Tst2-198114-025 & $8 / 4 / 2003$ & $9: 30$ & 3.82 & $<0.016$ \\
\hline Tst2-198114-029 & $8 / 4 / 2003$ & $20: 11$ & 4.27 & $<0.016$ \\
\hline Tst2-198114-033 & $8 / 5 / 2003$ & $6: 45$ & 4.71 & 0.012 \\
\hline Tst2-198114-036 & $8 / 5 / 2003$ & $9: 40$ & 4.83 & 0.013 \\
\hline Tst2-198114-037 & $8 / 5 / 2003$ & $20: 15$ & 5.27 & 0.010 \\
\hline Tst2-198114-042 & $8 / 6 / 2003$ & $7: 50$ & 5.75 & $<0.016$ \\
\hline Tst2-198114-043 & $8 / 6 / 2003$ & $12: 10$ & 5.93 & 0.011 \\
\hline Tst2-198114-046 & $8 / 6 / 2003$ & $20: 09$ & 6.27 & 0.016 \\
\hline Tst2-198114-047 & $8 / 7 / 2003$ & $6: 07$ & 6.68 & 0.014 \\
\hline
\end{tabular}


Table A-18: Continued

\begin{tabular}{|c|c|c|c|c|}
\hline Sample Name & Date & Time & $\begin{array}{c}\text { Time elapsed } \\
\text { (days) }\end{array}$ & 2,4-DFBA (mg/L) \\
\hline Tst2-198114-051 & $8 / 2 / 2003$ & $18: 01$ & 2.18 & 0.012 \\
\hline Tst2-198114-053 & 8/8/2003 & $6: 34$ & 7.70 & 0.012 \\
\hline Tst2-198114-055 & $8 / 8 / 2003$ & $10: 35$ & 7.87 & 0.011 \\
\hline Tst2-198114-059 & 8/9/2003 & $6: 25$ & 8.69 & $<0.016$ \\
\hline Tst2-198114-061 & $8 / 9 / 2003$ & $11: 40$ & 8.91 & 0.012 \\
\hline Tst2-198114-065 & 8/9/2003 & $20: 10$ & 9.27 & $<0.016$ \\
\hline Tst2-198114-067 & $8 / 10 / 2003$ & $6: 15$ & 9.69 & 0.014 \\
\hline Tst2-198114-071 & $8 / 10 / 2003$ & $11: 30$ & 9.91 & 0.013 \\
\hline Tst2-198114-075 & $8 / 10 / 2003$ & $18: 42$ & 10.21 & 0.012 \\
\hline Tst2-198114-078 & $8 / 11 / 2003$ & $14: 05$ & 11.01 & 0.012 \\
\hline Tst2-198114-079 & $8 / 11 / 2003$ & $20: 45$ & 11.29 & 0.010 \\
\hline Tst2-198114-083 & $8 / 12 / 2003$ & $5: 25$ & 11.65 & 0.010 \\
\hline Tst2-198114-089 & $8 / 13 / 2003$ & $5: 34$ & 12.66 & 0.010 \\
\hline Tst2-198114-093 & $8 / 11 / 2003$ & $5: 55$ & 10.67 & 0.012 \\
\hline Tst2-198114-095 & $8 / 13 / 2003$ & $10: 32$ & 12.87 & 0.009 \\
\hline Tst2-198114-099 & $8 / 13 / 2003$ & $20: 45$ & 13.29 & 0.012 \\
\hline Tst2-198114-101 & $8 / 14 / 2003$ & $6: 50$ & 13.71 & 0.010 \\
\hline Tst2-198114-105 & $8 / 14 / 2003$ & $20: 14$ & 14.27 & 0.009 \\
\hline Tst2-198114-111 & $8 / 15 / 2003$ & $20: 15$ & 15.27 & $<0.016$ \\
\hline Tst2-198114-113 & $8 / 16 / 2003$ & 8:03 & 15.76 & $<0.016$ \\
\hline Tst2-198114-115 & $8 / 16 / 2003$ & $10: 48$ & 15.88 & 0.010 \\
\hline Tst2-198114-117 & $8 / 16 / 2003$ & $10: 48$ & 15.88 & 0.009 \\
\hline Tst2-198114-119 & $8 / 16 / 2003$ & $20: 39$ & 16.29 & 0.011 \\
\hline Tst2-198114-121 & $8 / 17 / 2003$ & $6: 37$ & 16.70 & 0.011 \\
\hline Tst2-198114-122 & $8 / 17 / 2003$ & $11: 03$ & 16.89 & 0.012 \\
\hline Tst2-198114-123 & $8 / 17 / 2003$ & $20: 08$ & 17.27 & 0.009 \\
\hline Tst2-198114-124 & $8 / 18 / 2003$ & $9: 30$ & 17.82 & 0.009 \\
\hline Tst2-198114-125 & $8 / 18 / 2003$ & $12: 50$ & 17.96 & 0.009 \\
\hline Tst2-198114-126 & $8 / 18 / 2003$ & $19: 31$ & 18.24 & $<0.016$ \\
\hline Tst2-198114-127 & $8 / 19 / 2003$ & $8: 20$ & 18.77 & 0.016 \\
\hline Tst2-198114-129 & $8 / 20 / 2003$ & $9: 37$ & 19.83 & 0.009 \\
\hline Tst2-198114-131 & $8 / 20 / 2003$ & $20: 20$ & 20.27 & 0.009 \\
\hline Tst2-198114-133 & $8 / 21 / 2003$ & 9:00 & 20.80 & $<0.016$ \\
\hline Tst2-198114-137 & $8 / 22 / 2003$ & $10: 05$ & 21.85 & $<0.016$ \\
\hline Tst2-198114-139 & $8 / 23 / 2003$ & $9: 47$ & 22.83 & 0.009 \\
\hline Tst2-198114-143 & $8 / 25 / 2003$ & $8: 30$ & 24.78 & $<0.016$ \\
\hline Tst2-198114-145 & $8 / 26 / 2003$ & $9: 25$ & 25.82 & 0.008 \\
\hline Tst2-198114-147 & $8 / 28 / 2003$ & $15: 22$ & 28.07 & $<0.016$ \\
\hline Tst2-198114-151 & $8 / 29 / 2003$ & $14: 47$ & 29.04 & $<0.016$ \\
\hline Tst2-198114-153 & $9 / 2 / 2003$ & $9: 55$ & 32.84 & $<0.016$ \\
\hline Tst2-198114-157 & $9 / 3 / 2003$ & $12: 17$ & 33.94 & $<0.016$ \\
\hline Tst2-198114-163 & 9/8/2003 & $13: 25$ & 38.99 & 0.010 \\
\hline Tst2-198114-165 & 9/9/2003 & $11: 05$ & 39.89 & 0.011 \\
\hline
\end{tabular}


Table A-18: Continued

\begin{tabular}{|c|c|c|c|c|}
\hline Sample Name & Date & Time & $\begin{array}{c}\text { Time elapsed } \\
\text { (days) }\end{array}$ & 2,4-DFBA (mg/L) \\
\hline Tst2-198114-169 & $9 / 10 / 2003$ & $11: 00$ & 40.89 & 0.010 \\
\hline Tst2-198114-171 & $9 / 11 / 2003$ & $11: 07$ & 41.89 & 0.010 \\
\hline Tst2-198114-181 & $9 / 16 / 2003$ & $8: 18$ & 46.77 & 0.010 \\
\hline Tst2-198114-185 & $9 / 18 / 2003$ & $10: 05$ & 48.85 & $<0.016$ \\
\hline Tst2-198114-187 & $9 / 22 / 2003$ & $15: 05$ & 53.06 & 0.009 \\
\hline Tst2-198114-191 & $9 / 25 / 2003$ & $14: 45$ & 56.04 & 0.009 \\
\hline Tst2-198114-193 & $10 / 20 / 2003$ & $14: 32$ & 81.03 & 0.008 \\
\hline
\end{tabular}

Table A-19: HPLC data from test 2, lysimeter 198126

\begin{tabular}{|c|c|c|c|c|}
\hline Sample Name & Date & Time & $\begin{array}{c}\text { Time elapsed } \\
\text { (days) }\end{array}$ & 2,4-DFBA (mg/L) \\
\hline Tst2-198126-001 & $8 / 1 / 2003$ & $11: 50$ & 0.92 & 0.011 \\
\hline Tst2-198126-005 & $8 / 1 / 2003$ & $14: 28$ & 1.03 & 0.016 \\
\hline Tst2-198126-007 & $8 / 1 / 2003$ & $21: 15$ & 1.31 & $<0.016$ \\
\hline Tst2-198126-009 & $8 / 2 / 2003$ & $6: 14$ & 2.69 & 0.010 \\
\hline Tst2-198126-011 & $8 / 2 / 2003$ & $12: 26$ & 1.95 & $<0.016$ \\
\hline Tst2-198126-016 & $8 / 2 / 2003$ & $20: 38$ & 2.29 & 0.015 \\
\hline Tst2-198126-017 & $8 / 3 / 2003$ & $6: 16$ & 2.69 & 0.009 \\
\hline Tst2-198126-021 & $8 / 3 / 2003$ & $12: 04$ & 2.93 & 0.010 \\
\hline Tst2-198126-023 & $8 / 3 / 2003$ & $20: 16$ & 3.27 & $<0.016$ \\
\hline Tst2-198126-027 & $8 / 4 / 2003$ & $6: 50$ & 3.71 & $<0.016$ \\
\hline Tst2-198126-029 & $8 / 4 / 2003$ & $9: 40$ & 3.83 & $<0.016$ \\
\hline Tst2-198126-033 & $8 / 4 / 2003$ & $20: 15$ & 4.27 & $<0.016$ \\
\hline Tst2-198126-037 & $8 / 5 / 2003$ & $6: 50$ & 4.71 & $<0.016$ \\
\hline Tst2-198126-039 & $8 / 5 / 2003$ & $9: 50$ & 4.84 & $<0.016$ \\
\hline Tst2-198126-041 & $8 / 5 / 2003$ & $20: 09$ & 5.27 & $<0.016$ \\
\hline Tst2-198126-046 & $8 / 6 / 2003$ & $7: 55$ & 5.76 & $<0.016$ \\
\hline Tst2-198126-047 & $8 / 6 / 2003$ & $10: 18$ & 5.86 & $<0.016$ \\
\hline Tst2-198126-050 & $8 / 6 / 2003$ & $20: 14$ & 6.27 & $<0.016$ \\
\hline Tst2-198126-053 & 8/7/2003 & $5: 58$ & 6.68 & $<0.016$ \\
\hline Tst2-198126-059 & $8 / 8 / 2003$ & $6: 29$ & 7.70 & $<0.016$ \\
\hline Tst2-198126-063 & $8 / 8 / 2003$ & $10: 25$ & 7.86 & $<0.016$ \\
\hline Tst2-198126-065 & $8 / 8 / 2003$ & $17: 20$ & 8.15 & $<0.016$ \\
\hline Tst2-198126-069 & $8 / 9 / 2003$ & $11: 30$ & 8.91 & $<0.016$ \\
\hline Tst2-198126-071 & $8 / 9 / 2003$ & $20: 11$ & 9.27 & $<0.016$ \\
\hline Tst2-198126-075 & $8 / 10 / 2003$ & $6: 10$ & 9.68 & $<0.016$ \\
\hline Tst2-198126-077 & $8 / 10 / 2003$ & $11: 25$ & 9.90 & $<0.016$ \\
\hline Tst2-198126-081 & $8 / 10 / 2003$ & $18: 42$ & 10.21 & 0.011 \\
\hline Tst2-198126-085 & $8 / 11 / 2003$ & $6: 00$ & 10.68 & 0.013 \\
\hline Tst2-198126-088 & $8 / 11 / 2003$ & $14: 15$ & 11.02 & $<0.016$ \\
\hline Tst2-198126-089 & $8 / 11 / 2003$ & $20: 50$ & 11.30 & 0.016 \\
\hline Tst2-198126-093 & $8 / 12 / 2003$ & $5: 35$ & 11.66 & 0.013 \\
\hline
\end{tabular}


Table A-19: Continued

\begin{tabular}{|c|c|c|c|c|}
\hline Sample Name & Date & Time & $\begin{array}{c}\text { Time elapsed } \\
\text { (days) }\end{array}$ & 2,4-DFBA (mg/L) \\
\hline Tst2-198126-095 & $8 / 12 / 2003$ & $14: 40$ & 12.04 & 0.021 \\
\hline Tst2-198126-099 & $8 / 12 / 2003$ & 21:02 & 12.30 & $<0.016$ \\
\hline Tst2-198126-103 & $8 / 13 / 2003$ & $5: 37$ & 12.66 & 0.024 \\
\hline Tst2-198126-105 & $8 / 13 / 2003$ & $10: 35$ & 12.87 & 0.026 \\
\hline Tst2-198126-109 & $8 / 13 / 2003$ & $20: 42$ & 13.29 & 0.029 \\
\hline Tst2-198126-113 & $8 / 14 / 2003$ & $10: 39$ & 13.87 & 0.019 \\
\hline Tst2-198126-115 & $8 / 14 / 2003$ & $20: 08$ & 14.27 & 0.030 \\
\hline Tst2-198126-119 & $8 / 15 / 2003$ & $7: 55$ & 14.76 & 0.032 \\
\hline Tst2-198126-131 & $8 / 16 / 2003$ & $20: 34$ & 16.28 & 0.026 \\
\hline Tst2-198126-133 & $8 / 17 / 2003$ & $6: 43$ & 16.71 & 0.035 \\
\hline Tst2-198126-134 & $8 / 17 / 2003$ & $11: 05$ & 16.89 & 0.031 \\
\hline Tst2-198126-135 & $8 / 17 / 2003$ & 20:05 & 17.26 & 0.034 \\
\hline Tst2-198126-136 & $8 / 18 / 2003$ & $5: 35$ & 17.66 & 0.042 \\
\hline Tst2-198126-137 & $8 / 18 / 2003$ & $12: 50$ & 17.96 & 0.026 \\
\hline Tst2-198126-138 & $8 / 18 / 2003$ & 19:31 & 18.24 & 0.039 \\
\hline Tst2-198126-139 & $8 / 19 / 2003$ & $8: 25$ & 18.78 & 0.024 \\
\hline Tst2-198126-140 & $8 / 19 / 2003$ & $14: 45$ & 19.04 & 0.032 \\
\hline Tst2-198126-141 & $8 / 19 / 2003$ & 20:06 & 19.26 & 0.035 \\
\hline Tst2-198126-142 & $8 / 20 / 2003$ & $9: 45$ & 19.83 & 0.035 \\
\hline Tst2-198126-143 & $8 / 20 / 2003$ & $20: 11$ & 20.27 & 0.030 \\
\hline Tst2-198126-147 & $8 / 21 / 2003$ & $9: 10$ & 20.81 & 0.027 \\
\hline Tst2-198126-149 & $8 / 22 / 2003$ & $10: 17$ & 21.86 & 0.024 \\
\hline Tst2-198126-153 & $8 / 23 / 2003$ & $9: 40$ & 22.83 & 0.027 \\
\hline Tst2-198126-158 & $8 / 26 / 2003$ & $9: 27$ & 25.82 & 0.035 \\
\hline Tst2-198126-159 & $8 / 27 / 2003$ & $8: 47$ & 26.79 & 0.032 \\
\hline Tst2-198126-163 & $8 / 29 / 2003$ & $14: 50$ & 29.05 & 0.022 \\
\hline Tst2-198126-169 & $9 / 3 / 2003$ & $12: 19$ & 33.94 & 0.022 \\
\hline Tst2-198126-173 & $9 / 4 / 2003$ & $13: 45$ & 35.00 & 0.035 \\
\hline Tst2-198126-175 & $9 / 8 / 2003$ & $13: 30$ & 38.99 & 0.033 \\
\hline Tst2-198126-179 & 9/9/2003 & $11: 07$ & 39.89 & 0.041 \\
\hline Tst2-198126-181 & $9 / 10 / 2003$ & $11: 07$ & 40.89 & 0.046 \\
\hline Tst2-198126-185 & $9 / 11 / 2003$ & $11: 10$ & 41.89 & 0.045 \\
\hline Tst2-198126-187 & $9 / 15 / 2003$ & $10: 41$ & 45.87 & 0.047 \\
\hline Tst2-198126-191 & $9 / 16 / 2003$ & $8: 25$ & 46.78 & 0.044 \\
\hline Tst2-198126-193 & $9 / 18 / 2003$ & $10: 15$ & 48.85 & 0.043 \\
\hline Tst2-198126-199 & $9 / 25 / 2003$ & $15: 50$ & 56.09 & 0.032 \\
\hline
\end{tabular}


Table A-20: HPLC data from test 2, lysimeter 204129

\begin{tabular}{|c|c|c|c|c|}
\hline Sample Name & Date & Time & $\begin{array}{l}\text { Time elapsed } \\
\text { (days) }\end{array}$ & 2,4-DFBA (mg/L) \\
\hline Tst2-204129-005 & $8 / 1 / 2003$ & $12: 32$ & 0.95 & $<0.016$ \\
\hline Tst2-204129-009 & $8 / 1 / 2003$ & $18: 09$ & 1.18 & $<0.016$ \\
\hline Tst2-204129-011 & $8 / 2 / 2003$ & $5: 38$ & 1.66 & $<0.016$ \\
\hline Tst2-204129-013 & $8 / 2 / 2003$ & $11: 54$ & 1.92 & $<0.016$ \\
\hline Tst2-204129-017 & $8 / 2 / 2003$ & $20: 58$ & 2.30 & $<0.016$ \\
\hline Tst2-204129-019 & $8 / 3 / 2003$ & $5: 41$ & 2.66 & $<0.016$ \\
\hline Tst2-204129-021 & $8 / 3 / 2003$ & $12: 41$ & 2.96 & $<0.016$ \\
\hline Tst2-204129-025 & $8 / 3 / 2003$ & $20: 27$ & 3.28 & $<0.016$ \\
\hline Tst2-204129-027 & $8 / 4 / 2003$ & $6: 15$ & 3.69 & $<0.016$ \\
\hline Tst2-204129-033 & $8 / 4 / 2003$ & $20: 20$ & 4.27 & $<0.016$ \\
\hline Tst2-204129-037 & $8 / 5 / 2003$ & $6: 15$ & 4.69 & $<0.016$ \\
\hline Tst2-204129-039 & $8 / 5 / 2003$ & $10: 30$ & 4.86 & $<0.016$ \\
\hline Tst2-204129-041 & $8 / 5 / 2003$ & $21: 33$ & 5.33 & $<0.016$ \\
\hline Tst2-204129-047 & $8 / 6 / 2003$ & $6: 25$ & 5.69 & $<0.016$ \\
\hline Tst2-204129-050 & $8 / 6 / 2003$ & $13: 07$ & 5.97 & $<0.016$ \\
\hline Tst2-204129-051 & $8 / 6 / 2003$ & $20: 22$ & 6.28 & $<0.016$ \\
\hline Tst2-204129-053 & $8 / 7 / 2003$ & $5: 33$ & 6.66 & $<0.016$ \\
\hline Tst2-204129-055 & $8 / 7 / 2003$ & $18: 30$ & 7.20 & $<0.016$ \\
\hline Tst2-204129-059 & $8 / 8 / 2003$ & 7:03 & 7.72 & $<0.016$ \\
\hline Tst2-204129-061 & $8 / 8 / 2003$ & $10: 45$ & 7.88 & $<0.016$ \\
\hline Tst2-204129-066 & $8 / 8 / 2003$ & $17: 46$ & 8.17 & $<0.016$ \\
\hline Tst2-204129-069 & $8 / 9 / 2003$ & $11: 58$ & 8.93 & $<0.016$ \\
\hline Tst2-204129-073 & $8 / 9 / 2003$ & $20: 40$ & 9.29 & $<0.016$ \\
\hline Tst2-204129-075 & $8 / 10 / 2003$ & $5: 55$ & 9.67 & $<0.016$ \\
\hline Tst2-204129-079 & $8 / 10 / 2003$ & $12: 25$ & 9.94 & $<0.016$ \\
\hline Tst2-204129-081 & $8 / 10 / 2003$ & $19: 15$ & 10.23 & $<0.016$ \\
\hline Tst2-204129-084 & $8 / 11 / 2003$ & $6: 50$ & 10.71 & $<0.016$ \\
\hline Tst2-204129-087 & $8 / 11 / 2003$ & $9: 45$ & 10.83 & $<0.016$ \\
\hline Tst2-204129-089 & $8 / 11 / 2003$ & $20: 32$ & 11.28 & $<0.017$ \\
\hline Tst2-204129-093 & $8 / 12 / 2003$ & $6: 30$ & 11.70 & $<0.016$ \\
\hline Tst2-204129-096 & $8 / 12 / 2003$ & 13:05 & 11.97 & 0.006 \\
\hline Tst2-204129-101 & $8 / 13 / 2003$ & $11: 16$ & 12.90 & 0.012 \\
\hline Tst2-204129-109 & $8 / 14 / 2003$ & $6: 59$ & 13.72 & 0.012 \\
\hline Tst2-204129-111 & $8 / 14 / 2003$ & $20: 42$ & 14.29 & 0.017 \\
\hline Tst2-204129-113 & $8 / 15 / 2003$ & $8: 14$ & 14.77 & 0.024 \\
\hline Tst2-204129-117 & $8 / 15 / 2003$ & $19: 57$ & 15.26 & 0.031 \\
\hline Tst2-204129-119 & $8 / 16 / 2003$ & $8: 12$ & 15.77 & 0.027 \\
\hline Tst2-204129-125 & $8 / 16 / 2003$ & $20: 23$ & 16.28 & 0.044 \\
\hline Tst2-204129-128 & $8 / 17 / 2003$ & 7:00 & 16.72 & 0.045 \\
\hline Tst2-204129-129 & $8 / 17 / 2003$ & $11: 23$ & 16.90 & 0.060 \\
\hline Tst2-204129-130 & $8 / 17 / 2003$ & $20: 26$ & 17.28 & 0.062 \\
\hline Tst2-204129-131 & $8 / 18 / 2003$ & $6: 25$ & 17.69 & 0.065 \\
\hline Tst2-204129-132 & $8 / 18 / 2003$ & $10: 00$ & 17.84 & 0.074 \\
\hline
\end{tabular}


Table A-20: Continued

\begin{tabular}{|c|c|c|c|c|}
\hline Sample Name & Date & Time & $\begin{array}{c}\text { Time elapsed } \\
\text { (days) }\end{array}$ & 2,4-DFBA (mg/L) \\
\hline Tst2-204129-143 & $8 / 22 / 2003$ & $11: 09$ & 21.89 & 0.142 \\
\hline Tst2-204129-145 & $8 / 23 / 2003$ & $10: 37$ & 22.87 & 0.172 \\
\hline Tst2-204129-149 & $8 / 25 / 2003$ & $8: 41$ & 24.79 & 0.205 \\
\hline Tst2-204129-151 & $8 / 26 / 2003$ & $9: 45$ & 25.83 & 0.210 \\
\hline Tst2-204129-152 & $8 / 27 / 2003$ & $9: 03$ & 26.80 & 0.231 \\
\hline Tst2-204129-153 & $8 / 28 / 2003$ & $15: 50$ & 28.09 & 0.244 \\
\hline Tst2-204129-157 & $8 / 29 / 2003$ & $15: 25$ & 29.07 & 0.255 \\
\hline Tst2-204129-159 & $9 / 2 / 2003$ & $10: 20$ & 32.86 & 0.275 \\
\hline Tst2-204129-163 & $9 / 3 / 2003$ & $12: 35$ & 33.95 & 0.279 \\
\hline Tst2-204129-169 & $9 / 8 / 2003$ & $13: 50$ & 39.00 & 0.238 \\
\hline Tst2-204129-171 & $9 / 9 / 2003$ & $11: 25$ & 39.90 & 0.250 \\
\hline Tst2-204129-177 & $9 / 11 / 2003$ & $11: 30$ & 41.91 & 0.223 \\
\hline Tst2-204129-181 & $9 / 15 / 2003$ & $10: 59$ & 45.88 & 0.220 \\
\hline Tst2-204129-183 & $9 / 16 / 2003$ & $8: 43$ & 46.79 & 0.198 \\
\hline Tst2-204129-187 & $9 / 18 / 2003$ & $10: 55$ & 48.88 & 0.192 \\
\hline Tst2-204129-193 & $9 / 25 / 2003$ & $15: 05$ & 56.06 & 0.150 \\
\hline Tst2-204129-195 & $10 / 20 / 2003$ & $14: 50$ & 81.05 & 0.093 \\
\hline
\end{tabular}




\section{APPENDIX B: CALCULATION OF VERTICAL SATURATED HYDRAULIC CONDUCTIVITY OF THE C-D INTERBED}

Method 1: Calculation using results of Well 202A/Lysimeter 204129(I) analysis

Assumptions:

1. Sedimentary material was saturated.

2. Water was perched above the interbed. A pressure head of $316 \mathrm{~cm} \mathrm{H}_{2} \mathrm{O}$ at the top of the interbed was assumed. This assumption was based on the average water level in Well 202 for the duration of test 2.

3. Water was draining freely out the bottom of the interbed into the basalt below (i.e., the pressure head at the bottom surface of the interbed was zero).

4. The thickness of the interbed, and thus the vertical travel distance, was $1.98 \mathrm{~m}$ (based on geologic log of well 202A).

The form of the Darcy equation used was:

$\mathrm{Q}=\mathrm{KIA}$ which was rearranged and solved for $\mathrm{K}$ :

$\mathrm{q}=\mathrm{KI}$

$\mathrm{v}=\mathrm{KI} / \mathrm{n}$

$\mathrm{K}=\mathrm{vn} / \mathrm{I}$

where:

$\mathrm{Q}=$ volumetric flux

$\mathrm{K}=$ vertical saturated hydraulic conductivity

I = vertical hydraulic gradient

$A=$ area through which flux is passing

$q=$ specific discharge 
$\mathrm{v}=$ average linear velocity

$\mathrm{n}=$ porosity

The values used in this calculation were:

$\mathrm{v}=0.12 \mathrm{~m} /$ day (from inverse fit of the Test 2 Lysimeter 204129 BTC; see text)

$\mathrm{n}=0.496$ (average laboratory porosity for C-D interbed sediments (Winfield, 2002)

$\mathrm{I}=(3.16 \mathrm{~m}+1.98 \mathrm{~m}) /(1.98 \mathrm{~m})=0.26$

Therefore: $\mathrm{K}=\mathrm{vn} / \mathrm{I}$

$$
\begin{aligned}
& =(12 \mathrm{~m} / \mathrm{d}) *(0.496) /((3.16 \mathrm{~m}+1.98 \mathrm{~m}) /(1.98 \mathrm{~m})) \\
& =\mathbf{2} \times \mathbf{1 0}^{-\mathbf{2}} \mathbf{~} \mathbf{d a y}
\end{aligned}
$$

Method 2: Calculation using water-balance approach

Assumptions:

1. Sedimentary material was saturated.

2. Water flowed radially along the C-D interbed and formed a circular wetted area with its center at the center of the south pond. The calculation was carried out for two bounding cases. The minimum radius was the distance between the center of the south pond and well 197 (268 m); the maximum radius was the distance between the center of the south pond and well 194 (449 m). See the text for further explanation. These radii were used to calculate the minimum and maximum areas through which water percolated vertically $\left(2.3 \times 10^{5} \mathrm{~m}^{2}\right.$ and $6.3 \mathrm{x}$ $10^{5} \mathrm{~m}^{2}$, respectively). 
3. Water was perched above the interbed. A pressure head of $4 \mathrm{~m} \mathrm{H}_{2} \mathrm{O}$ at the top of the interbed was assumed. This head was calculated as the arithmetic mean of the average water level at wells 197, 211 and 202A for the duration of test 1.

4. Water was draining freely out the bottom of the interbed into the basalt below (i.e., the pressure head at the bottom surface of the interbed was zero).

5. The average thickness of the interbed, and thus the average vertical travel distance, was $4 \mathrm{~m}$ (based on the arithmetic mean of the average thicknesses of the C-D interbed in the geologic logs of wells 195, 198, 204, 205, 207, and 212).

As above, the form of the Darcy equation used was:

$\mathrm{Q}=\mathrm{KIA}$ which was rearranged and solved for $\mathrm{K}$ :

$\mathrm{K}=\mathrm{Q} /(\mathrm{A} * \mathrm{I})$

The values used in this calculation were:

$\mathrm{Q}=3785 \mathrm{~m}^{3} /$ day (average discharge to the south pond during test 1 )

$A_{\min }=2.3 \times 10^{5} \mathrm{~m}^{2}$ (see explanation above)

$A_{\max }=6.3 \times 10^{5} \mathrm{~m}^{2}$ (see explanation above)

$\mathrm{I}=2$ (calculated from the average head of $4 \mathrm{~m}$ overlying an average vertical thickness of C-D interbed of 4m)

Variables as defined for Method 1 above.

Therefore: $\mathrm{K}_{\max }=\mathrm{Q} /\left(\mathrm{A}_{\min }{ }^{*} \mathrm{I}\right)$

$$
=\left(3785 \mathrm{~m}^{3} / \text { day }\right) /\left(\left(2.3 \times 10^{5} \mathrm{~m}^{2}\right) *(2)\right)
$$




$$
=8 \times 10^{-3} \mathrm{~m} / \mathrm{day}
$$

And: $\quad \mathrm{K}_{\min }=\mathrm{Q} /\left(\mathrm{A}_{\max }{ }^{*} \mathrm{I}\right)$

$$
\begin{aligned}
& =\left(3785 \mathrm{~m}^{3} / \text { day }\right) /\left(\left(6.3 \times 10^{5} \mathrm{~m}^{2}\right) *(2)\right) \\
& =\mathbf{3} \times \mathbf{1 0}^{-\mathbf{3}} \mathbf{~} \mathbf{m} \mathbf{d a y}
\end{aligned}
$$




\section{APPENDIX C: DISCUSSION OF POWER-LAW TAILING BEHAVIOR}

Figure C-1 shows BTCs from wells completed at the basalt/interbed contact plotted with log normalized concentration (sample concentration divided by injected mass) on the y-axis and log normalized time (elapsed time divided by mean fluid residence time)on the $\mathrm{x}$-axis. Late time mass recovery from wells completed at the basalt/interbed contact is a power-law function of time. This is in contrast to true Fickian behavior as represented by the advection-dispersion equation in which BTC tails decay exponentially. In saturated fractured media, multiple flow paths have been shown to result in breakthrough tailing (Becker and Shapiro, 2003; Robinson and Tester, 1986). Becker and Shapiro (2003) show that multiple flow paths, each separately well-described by the ADE, may sum to a resultant BTC with a power-law tail. Thus, the power-law tailing behavior so strongly demonstrated by the BTCs from the deeper wells in this study combines with the bimodal BTC evidence to indicate that multiple flow paths are activated during infiltration through the alluvium/basalt complex.

It is interesting to consider the power law slopes of the BTCs that represent transport through the alluvium/basalt complex. Three of the five BTCs have slopes of -2 with one BTC having a shallower slope ( -1$)$ and one having a steeper slope (-3.4). Becker and Shapiro (2003) found that in radially convergent and weak dipole tracer tests carried out in the saturated, fractured crystalline rock at Mirror Lake, BTCs consistently displayed a power-law slope of -2 . The authors concluded that the consistent behavior between the two test configurations was due to the fact that under forced gradient conditions water flow through a fractured system is highly channelized. The tracer test design in this study is similar to the Becker and Shapiro study in that it is forced gradient; 
however the geometry is very different being essentially radially divergent rather than convergent. Additionally the system in this study is variably-saturated in contrast with the saturated system of the Becker and Shapiro study. The similarity in results supports our conclusion that flow through the fractured basalt at the VZRP occurs through multiple preferential flow paths. However, the BTCs from the current study also incorporate the effects of matrix diffusion which was ruled out as a transport mechanism in the Mirror Lake study. Tsang (1995) identified a power-law slope of -1.5 as being diagnostic of matrix diffusion (although this signature may be obscured in highly heterogeneous media under some tracer test configurations). Clearly a challenge in analyzing breakthrough behavior is to deconvolve the relative contributions of heterogeneity and matrix diffusion to the power-law tailing behavior and thus to transport through variably-saturated media.

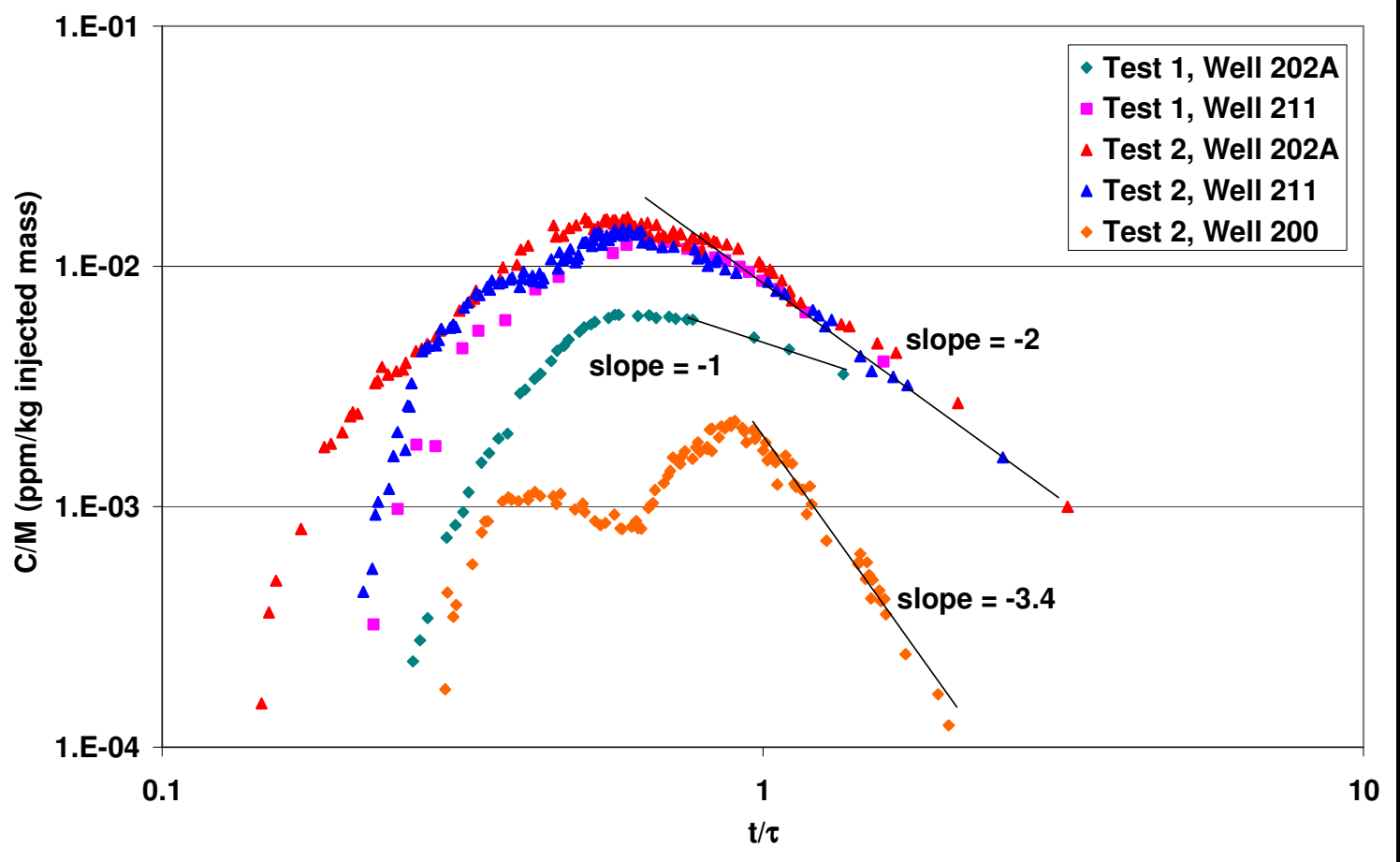

Figure C-1: BTCs from wells completed at the alluvium/basalt contact demonstrating power-law tailing behavior 


\section{APPENDIX D: DISCUSSION OF DISPERSION COEFFICIENTS YIELDED BY CXTFIT MODELING}

Dispersion is a concept used to explain and quantify mixing and spreading during solute transport. When transport is described using the advection-dispersion equation, dispersion is quantified using a dispersion coefficient that is analogous to the Fickian diffusion coefficient. In small-scale transport through homogeneous porous media, dispersion is fairly easily visualized as being due to velocity variations caused by porescale processes (e.g. Freeze and Cherry, 1979). However, at the field scale the concept of dispersion becomes more complex. In porous media, spreading may be due to permeability contrasts due to layers or lenses of different material. At the regional scale, a plume may be spread through interaction with fault zones or changes in depositional environment. In fractured materials dispersion is even more complicated as mixing may occur within fractures due to flow channeling, and at fracture intersections. On a larger scale, spreading is fundamentally linked with the geometry and connectivity of the fracture network.

The BTCs generated by the two tracer tests discussed in this thesis were fitted to solutions to the one-dimensional advection-dispersion equation using the CXTFIT code (Parker and van Genuchten, 1984; Toride et al., 1999). The mathematics of this method is discussed in the manuscript (Section II). This fitting process yielded estimates of average linear flow velocity (v) and longitudinal dispersion coefficient $\left(D_{L}\right)$. The model assumes that a single, homogeneous flow pathway exists between the surface and each well, and that that pathway can be described by a time- and space-invariant velocity and dispersion coefficient. 
Dispersion coefficients from a 1-D analysis of the BTCs obtained from this study are not particularly meaningful for several reasons:

1. Unsteady flow. In unsaturated fracture flow it is common for flow to pulse as pathways wet up and become transmissive. True steady flow in the porous medium tradition is not a good assumption. Film flow, fingering, and flow channeling within fractures have all been shown to contribute to intermittent flow patterns even during apparently steady state infiltration (e.g. Mortensen et al. (2004), and references therein). Faybishenko et al. (2000) observed that during the Box Canyon infiltration test, some fractures that were saturated at the beginning of the test became unsaturated at later times. This was interpreted by the authors as evidence that steady-state conditions did not develop despite the fact that infiltration rates approached a stable value within 1-2 days. Deviations from the mean velocity due to unsteady flow are accounted for in the dispersion coefficient and so lead to higher estimates than would be obtained from a true steady-flow experiment.

2. Multi-dimensional flow. If the flow is two or three-dimensional, large deviations from the 1-D velocity assumption will be incorporated into the dispersion coefficient. Flow during tests 1 and 2 was fundamentally multi-dimensional as water flowed vertically through the alluvium and the basalt but spread laterally along geologic contacts before reaching the sampling points.

3. Spatial and temporal spreading of the input signal. In both tests tracers had infiltrated within two hours, which compared with residence times on the order of days to weeks, makes the instantaneous injection assumption fairly reasonable. 
However, in test 1 , tracer spread over almost the entire wetted surface of the pond, and in test 2, although tracer was constrained to a smaller area on the surface, the degree to which is spread just below the surface is unknown. Thus although the pulse input assumption seems reasonable, the planar source assumption is clearly violated in this experiment. Spatial spreading of the input signal will contribute to larger estimates of dispersion.

4. Due to the design of this experiment in which divergent flow was sampled at discrete points, there is no reason to believe that any given BTC is actually intercepting the center of the tracer plume or that multiple BTCs represent transport in a similar part of the plume. For this reason, perhaps more than any of the preceding reasons, the dispersion coefficient values calculated from these data provide qualitative information at best.

For the sake of completeness the longitudinal dispersion coefficients yielded by the CXTFIT model are shown in Table D-1. Also provided in Table D-1 are dispersivity $(\alpha)$ and Peclet (Pe) values calculated from the dispersion coefficients. Dispersivity is a characteristic property of a porous medium and is calculated as: $\alpha=D_{L} / v$. The Peclet number is a dimensionless number that describes the relative contributions of advective and dispersive processes to transport and is calculated here as: $\mathrm{Pe}=\mathrm{xv} / \mathrm{D}_{\mathrm{L}}$ (consistent with Fetter (1999)). The larger the Peclet number the smaller the contribution of dispersive processes to transport through the medium in question. Peclet numbers become larger with longer flow distances and higher velocities. The Peclet numbers shown in Table D-1 indicate that advective processes dominate over dispersive processes 
Table D-1: Summary of CXTFIT transport parameters and calculated dispersivities $(\alpha)$ and Peclet numbers $(\mathrm{Pe})$

\begin{tabular}{|c|c|c|c|c|c|c|}
\hline Well & Geologic domain & $x(m)$ & $\begin{array}{c}\mathbf{V} \\
\text { (m/day) }\end{array}$ & $\begin{array}{c}\mathrm{D}_{\mathrm{L}} \\
\left(\mathrm{m}^{2} / \text { day }\right) \\
\end{array}$ & $\begin{array}{l}\alpha(m ; \\
\left.D_{L} / v\right)\end{array}$ & $\begin{array}{c}\mathrm{Pe} \\
\left(x v / D_{L}\right)\end{array}$ \\
\hline \multicolumn{7}{|c|}{ TEST 1} \\
\hline $210 \max$ & Alluvium & 145 & 41 & 560 & 14 & 11 \\
\hline $210 \min$ & Alluvium & 85 & 24 & 192 & 8 & 11 \\
\hline $202 \max$ & Alluvium/basalt & 166 & 8 & 168 & 21 & 8 \\
\hline $202 \min$ & Alluvium/basalt & 124 & 6 & 94 & 16 & 8 \\
\hline $211 \max$ & Alluvium/basalt & 157 & 13 & 298 & 23 & 7 \\
\hline $211 \min$ & Alluvium/basalt & 97 & 8 & 114 & 14 & 7 \\
\hline \multicolumn{7}{|c|}{ TEST 2} \\
\hline 199 & Alluvium & 136 & 13 & 213 & 16 & 8 \\
\hline 200 pk 1 & Alluvium/basalt & 129 & 20 & 112 & 6 & 23 \\
\hline 200 pk 2 & Alluvium/basalt & 129 & 10 & 54 & 5 & 24 \\
\hline $202 \mathrm{~A}$ & Alluvium/basalt & 131 & 5 & 126 & 25 & 5 \\
\hline 211 & Alluvium/basalt & 194 & 6 & 203 & 34 & 6 \\
\hline Lys 204129 & Alluvium/basalt/interbed & 146 & 3 & 46 & 15 & 10 \\
\hline Lys 204129 with 202 input & Interbed & 1.98 & 0.12 & 0.03 & 0.3 & 8 \\
\hline
\end{tabular}

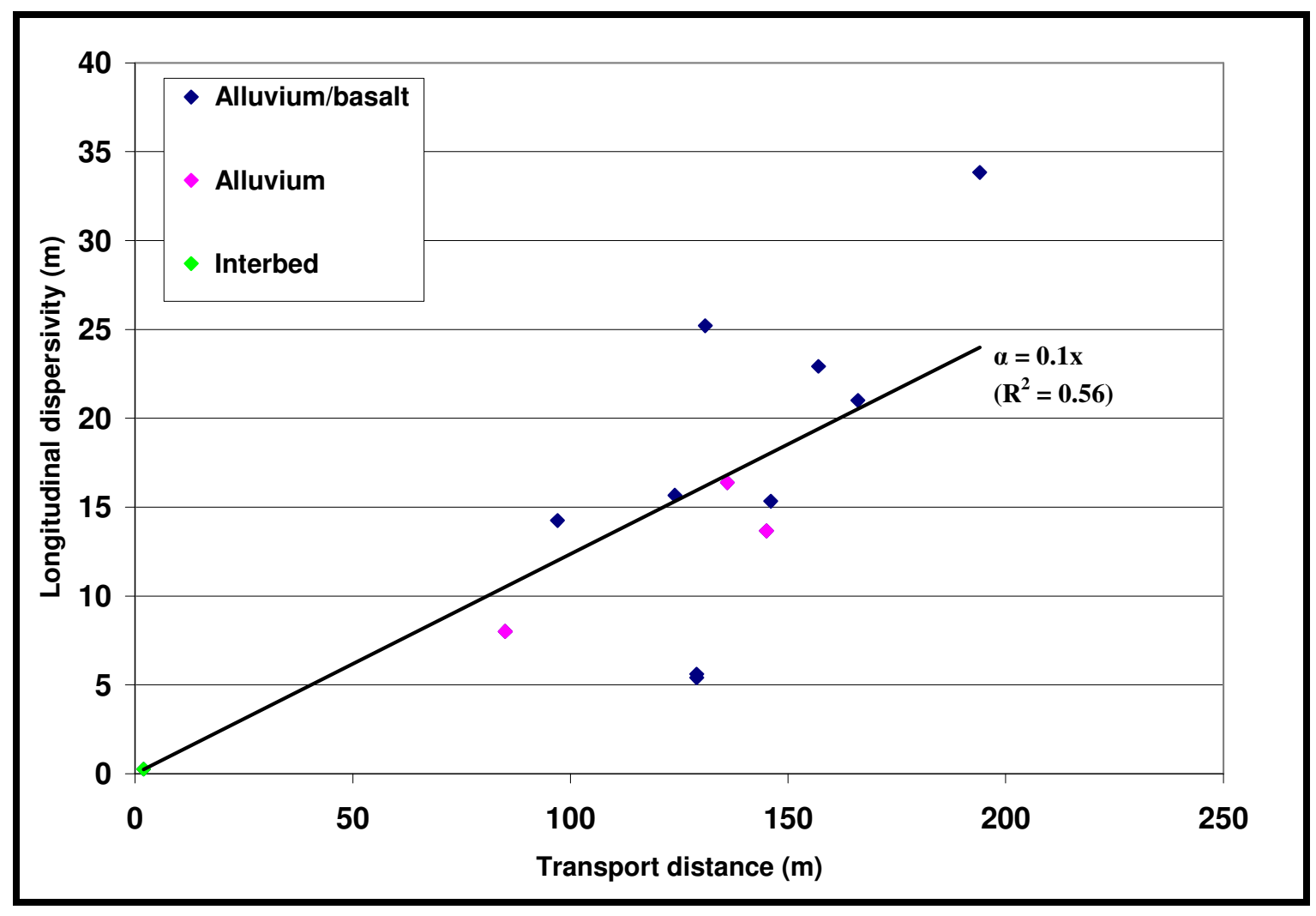

Figure D-1: Plot of longitudinal dispersivity (m) vs. transport distance (m) 
with no apparent difference between the three geologic domains sampled (alluvium, alluvium/basalt, and interbed). An interesting trend that is apparent is a positive correlation between travel distance and dispersivity with a slope of 0.1 (Figure D-1). The tendency for dispersivity to be scale-dependent has long been recognized (Gelhar, 1986; 1992) though due to the difficulty in generating highly-constrained, field-scale, transport data this relationship has yet to be quantified with confidence. As discussed in Fetter (1999), Lallemand-Barres and Peaudecerf (1978) found a similar relationship between dispersivity and transport distance (i.e. $\alpha=0.1 \mathrm{x})$. However, work by Gelhar (1986; 1992)), that included more data covering a larger span of travel distances, suggested that transport behavior deviates from this simple relationship at longer travel distances. As Gelhar pointed out though, the reliability of data gathered over much longer transport distances $(>1000 \mathrm{~m})$ is low. The results of the current study, although based on dispersivity data that are also of low reliability, seem to support the idea that when transport distances are relatively small (on the order of $100 \mathrm{~s}$ of $\mathrm{m}$ or less) the relationship between dispersivity and transport distance advanced by Lallemand-Barres and Peaudecerf (1978) holds in both the alluvium and the integrated alluvium/basalt complex at INL. The one data point obtained from this study concerning transport through the sedimentary interbeds also lies on the $\alpha=0.1 \mathrm{x}$ line however, many more data need to be collected before this relationship can be defined with confidence. 


\section{THESIS REFERENCES}

Ackerman, D. J. (1991), Transmissivity of perched aquifers at the Idaho National Engineering Laboratory, Idaho, Water-resources investigations report, 91-4114, USGS, Idaho Falls.

Adam, M. L., Comfort, S. D., Morley, M. C., and Snow, D. D. (2004), Remediating RDX-contaminated ground water with permanganate: Laboratory investigations for the Pantex perched aquifer, Journal of Environmental Quality, 33, 2165-2173.

Anderson, S. R., and Lewis, B. D. (1989), Stratigraphy of the unsaturated zone at the radioactive waste management complex, Idaho National Engineering Laboratory, Idaho, Water-Resources Investigations Report, 89-4065, USGS, Idaho Falls.

Baker, K. E., Hull, L. C., Bennett, J., Ansley, S. L., and Heath, G. (2004), Conceptual models of flow through a heterogeneous, layered vadose zone under a percolation pond, INEEL/EXT-04-01679, INEEL, Idaho Falls.

Barraclough, J. T., Robertson, J. B., and Janzer, V. J. (1976), Hydrology of the solid waste burial ground, as related to the potential migration of radionuclides, Idaho National Engineering Laboratory, Open-File Report, 76-471, USGS, Idaho Falls.

Bear, J. (1972), Dynamics of fluids in porous media, 764 pp., Elsevier, New York.

Becker, M. W., and Shapiro, A. M. (2003), Interpreting tracer breakthrough tailing from different forced-gradient tracer experiment configurations in fractured bedrock, Water Resources Research, 39, doi:10.1029/2001WR001190.

Bishop, C. W. (1991), Hydraulic properties of vesicular basalt, M.S. thesis, University of Arizona. 
Cecil, L. D., Orr, B. R., Norton, T., and Anderson, S. R. (1991), Formation of perched ground-water zones and concentrations of selected chemical constituents in water, Idaho National Engineering Laboratory, Idaho, 1986-1988, Water-Resources Investigations, 91-4166, DOE/ID-22100, USGS, Idaho Falls, ID.

DOE-ID (2006), Operable unit 3-14 tank farm soil and groundwater remedial investigation/baseline risk assessment, DOE/NE-ID-11227, Rev. 0, U.S. Department of Energy Idaho Operations Office.

Doughty, C. (2000), Numerical model of water flow in a fractured basalt vadose zone: Box Canyon site, Idaho, Water Resources Research, 36, 3521-3534.

Dunnivant, F. M., Newman, M. E., Bishop, C. W., Burgess, D., Giles, J. R., Higgs, B. D., Hubbell, J. M., Neher, E., Norrell, G. T., Pfiefer, M. C., Porro, I., Starr, R. C., and Wyllie, A. H. (1998), Water and radioactive tracer flow in a heterogeneous field-scale system, Ground Water, 36, 949-958.

Dunnivant, F. M., Newman, M. E., Magnuson, S. O., and McCarthy, J. (1995), Modeling of radioactive tracer data collected during the large-scale pumping and infiltration test: water velocity and dispersivity estimates, Eos Trans., 76, Suppl., 266.

Fabryka-Martin, J., Wightman, S. J., Murphy, W. J., Wickham, M. P., Caffee, M. W., Nimz, G. J., Southon, J. R., and Sharma, P. (1993), Distribution of chlorine-36 in the unsaturated zone at Yucca Mountain: an indicator of fast transport paths, paper presented at FOCUS '93, Site Characterization and Model Validation, American Nuclear Society, Las Vegas, NV.

Fabryka-Martin, J., Wightman, S. J., Robinson, B. A., and Vestal, E. W. (1994), Infiltration processes at Yucca Mountain inferred from chloride and chlorine-36 
distributions, Los Alamos National Laboratory Milestone Report, 4317, Los Alamos, NM.

Faybishenko, B., Doughty, C., Steiger, M., Long, J. C. S., Wood, T. R., Jacobsen, J. S., Lore, J., and Zawislanski, P. T. (2000), Conceptual model of the geometry and physics of water flow a fractured basalt vadose zone, Water Resources Research, 36, 3499-3520.

Fetter, C.W. (1999), Contaminant Hydrogeology, Prentice Hall, Upper Saddle River, NJ, 500 pp.

Finsterle, S., Fabryka-Martin, J. T., and Wang, J. S. Y. (2002), Migration of a water pulse through fractured porous media, Journal of Contaminant Hydrology, 54, 37-57.

Flint, A. L., Flint, L. E., Bodvarsson, G. S., Kwicklis, E., and Fabryka-Martin, J. (2001a), Evolution of the conceptual model of unsaturated zone hydrology at Yucca Mountain, Nevada, Journal of Hydrology, 247, 1-30.

Flint, A. L., Flint, L. E., Kwicklis, E. M., Bodvarsson, G. S., and Fabryka-Martin, J. M. (2001b), Hydrology of Yucca Mountain, Nevada, Reviews of Geophysics, 39, 447470.

Freeze, R.A., and Cherry, J.A. (1979), Groundwater, Prentice Hall, Englewood Cliffs, NJ, 604 pp.

Gauthier, J. H., Wilson, M. L., and Lauffer, F. C. (1992), Estimating the consequences of significant fracture flow at Yucca Mountain, paper presented at Third Annual International High-Level Radioactive Waste Management Conference, American Nuclear Society, LaGrange Park, IL. 
Gelhar, L. W., Welty, C. and Rehfeldt, K. R. (1992), A critical review of data on fieldscale dispersion in aquifers, Water Resources Research 28(7): 1955-1974.

Gelhar, L.W. (1986), Stochastic subsurface hydrology from theory to applications, Water Resources Research, 22:135S-145S.

Haggerty, R., McKenna, S. A., and Meigs, L. C. (2000), On the late-time behavior of tracer test breakthrough curves, Water Resources Research, 36, 3467-3479.

Hull, L. C., and Bishop, C. W. (2003), Fate of brine applied to unpaved roads at a radioactive waste subsurface disposal area, Vadose Zone Journal, 3, 190-202.

Illman, W. A. and Hughson, D.L. (2005), Stochastic simulations of steady state unsaturated flow in a three-layer, heterogeneous, dual continuum model of fractured rock, Journal of Hydrology, 307, 17-37.

Knutson, C. F., McCormick, K. A., Crocker, J. C., Glenn, M. A., and Fishel, M. L. (1992), 3D RWMC vadose zone modeling, EGG-ERD-10246, EG\&G, Idaho Falls, ID.

Lallemand-Barres, A., and Peaudecerf, P. (1978) Recherche des relations entre la valeur de la dispersivité macroscopique d'un milieu aquifère, ses autres caractéristiques et les conditions des mesure, Bulletin, Bureau de Recherches Geologiques et Miniéres, (3/4): 277-284.

Liu, H.-H., C. Doughty, and G. S. Bodvarsson, 1998. An active fracture model for unsaturated flow and transport in fractured rocks, Water Resources Research, 34, 2633-2646. 
Magnuson, S. O. (1995), Inverse modeling for field-scale hydrologic and transport parameters of fractured basalt, INEL-95/0637, Idaho National Engineering Laboratory.

Magnuson, S. O. (2004), Regulatory modeling for the Idaho National Engineering and Environmental Laboratory's Subsurface Disposal Area and conceptual model uncertainty treatment, Vadose Zone Journal, 3, 59-74.

Magnuson, S. O., and Sondrup, A. J. (2006), Subsurface flow and transport model development for the operable unit 7-13/14 remedial investigation and feasibility study, ICP/EXT-05-01016, Idaho Cleanup Project, Idaho Falls, ID.

Maloszewski, P., and Zuber, A. (1993), Tracer experiments in fractured rocks: Matrix diffusion and the validity of models, Water Resources Research, 29, 2723-2735.

Mattson, E. D., Magnuson, S. O., and Ansley, S. L. (2004), Interpreting INEEL vadose zone water movement on the basis of large-scale field tests and long-term vadose zone monitoring results, Vadose Zone Journal, 3, 35-46.

McLaren, R.G., Forsyth, P.A., Sudicky, E.A., VanderKwaak, J.E., Schwartz, F.W., and Kessler, J.H. (2000), Flow and transport in fractured tuff at Yucca Mountain: numerical experiments on fast preferential flow mechanisms, Journal of Contaminant Hydrology, 43, 211-238.

Mohanty, B. P., Bowman, R. S., Hendrickx, J. M. H., Simunek, J., and van Genuchten, M. T. (1998), Preferential transport of nitrate to a tile drain in an intermittent-floodirrigated field: Model development and experimental evaluation, Vadose Zone Journal, 34, 1061-1076. 
Montazer, P., and Wilson, W. E. (1984), Conceptual hydrologic model of flow in the unsaturated zone, Yucca Mountain, Nevada, U.S. Geological Survey Water Resources Investigation Report, 84-4345, 29 pp.

Mortensen, A. P., Jensen, K. H., Nilsson, B., and Juhler, R. K. (2004), Multiple tracing experiments in unsaturated fractured clayey till, Vadose Zone Journal, 3, 634-644.

Neretnieks, I. (1993), Solute transport in fractured rock--applications to radionuclide waste repositories, in Flow and contaminant transport in fractured rock, J. Bear, C.-F. Tsang, and G. de Marsily, pp. 39-127, Academic Press, Inc., San Diego.

Newman, M. E., and Dunnivant, F. M. (1995), Results from the large-scale aquifer pumping and infiltration tests: Transport of tracers through fractured media, INEL95/146 ER-WAG7-77, Idaho National Engineering and Environmental Laboratory.

Nimmo, J. R., Perkins, K. S., Rose, P. E., Rousseau, J. P., Orr, B. R., Twining, B. V., and Anderson, S. R. (2002), Kilometer-scale rapid transport of naphthalene sulfonate tracer in the unsaturated zone at the Idaho National Engineering and Environmental Laboratory, Vadose Zone Journal, 1, 89-101.

Nimmo, J. R., Perkins, K. S., and Winfield, K. A. (2004a), Unsaturated-zone case study at the Idaho National Engineering and Environmental Laboratory: Can Darcian hydraulic properties predict contaminant migration?, paper presented at Geological Society of America, Denver, CO.

Nimmo, J. R., Rousseau, J. P., Perkins, K. S., Stollenwerk, K. G., Glynn, P. D., Bartholomay, R. C., and Knobel, L. L. (2004b), Hydraulic and geochemical framework of the Idaho National Engineering and Environmental Laboratory vadose zone, Vadose Zone Journal, 3, 6-34. 
Parker, J. C., and van Genuchten, M. T. (1984), Determining transport parameters from laboratory and field tracer experiments, paper presented at Bull. Va. Agric. Exp. St., Blacksburg.

Peters, R. R., and Klavetter, E. A. (1988), A continuum model for water movement in an unsaturated fractured rock mass, Water Resources Research, 24, 416-430.

Pruess, K. (1999), A mechanistic model for water seepage through thick unsaturated zones in fractured rocks of low matrix permeability, Water Resources Research, 35, 1039-1051.

Rightmire, C. T., and Lewis, B. D. (1987), Hydrogeology and geochemistry of the unsaturated zone, Radioactive Waste Management Complex, Idaho National Engineering Laboratory, Idaho, Water-Resources Investigations Report, 87-4198, USGS.

Robinson, B. A., Broxton, D. E., and Vaniman, D. T. (2005), Observations and modeling of deep perched water beneath the Pajarito Plateau, Vadose Zone Journal, 4, 637-652.

Robinson, B., and Tester, J. (1986), Characterization of flow maldistribution using inletoutlet tracer techniques: An application of internal residence time distributions, Chemical Engineering Science, 41, 469-484.

Schaefer, C. J., and Kattenhorn, S. A. (2004), Characterization and evolution of fractures in low-volume pahoehoe lava flows, eastern Snake River Plain, Idaho, Geological Society of America Bulletin, 116(3): 322-336.

Smith, R. P. (2004), Geologic setting of the Snake River Plain Aquifer and Vadose Zone, Vadose Zone Journal, 3, 47-58. 
Toride, N., Leij, F. J., and van Genuchten, M. T. (1999), The CXTFIT code for estimating transport parameters from laboratory or field tracer experiments, Research report no. 137, U.S. Salinity Laboratory, USDA, Riverside, CA.

Tsang, Y. W. (1995), Study of alternative tracer tests in characterizing transport in fractured rocks, Geophysical Research Letters, 22, 1421-1424.

Wang, J. S. Y., and Narasimhan, T. N. (1985), Hydrologic mechanisms governing fluid flow in a partially saturated, fractured, porous medium, Water Resources Research, $21,1861-1874$.

Wang, J. S. Y., and Narasimhan, T. N. (1993), Unsaturated flow in fractured porous media, in Flow and contaminant transport in fractured rock, J. Bear, C.-F. Tsang, and G. de Marsily, pp. 325-394, Academic Press, Inc., San Diego.

Winfield, K. A. (2002), Measurement of unsaturated hydraulic conductivity functions, saturated hydraulic conductivity, particle-size distribution bulk density, porosity, and specific surface area for Vadose Zone Research Park samples, Idaho National Engineering and Environmental Laboratory (INEEL), Summary Report, USGS, Menlo Park, CA.

Winfield, K. A. (2003), Spatial variability of sedimentary interbed properties near the Idaho Nuclear Technology and Engineering Center at the Idaho National Engineering and Environmental Laboratory, Idaho, Water-Resources Investigations Report, 034142, USGS, Idaho Falls, ID.

Wood, T. R., and Norrell, G. T. (1996), Integrated large-scale aquifer pumping and infiltration tests: Groundwater pathways OU 7-06 Summary report, INEL-96/0256, Idaho National Engineering and Environmental Laboratory, Idaho Falls, ID. 
Yang, I. C., Rattray, G. W., and Yu, P. (1996), Interpretations of chemical and isotopic data from boreholes in the unsaturated-zone at Yucca Mountain, Nevada, WaterResources Investigations Report, 96-4058, USGS. 